\title{
INFLUÊNCIA DA CONDUÇÃO DA DESTILAÇÃO SOBRE A COMPOSIÇÃO E A QUALIDADE SENSORIAL DA AGUARDENTE DE CANA
}

\section{YOLANDA EUGÊNIA ÁLAMO GABRINE BOZA \\ Química}

Orientador: Prof. Dr. JORGE HORII

\begin{abstract}
Dissertação apresentada à Escola Superior de Agricultura "Luiz de Queiroz" da Universidade de São Paulo, para obtenção do título de Mestre em Ciências. Área de Concentração: Ciência e Tecnologia de Alimentos
\end{abstract}

P I R A C I C A B A

Estado de São Paulo - Brasil

Abril - 1996 
Dados Internacionais de Catalogaçāo na Publicaçāo (CIP) DIVISĀo DE BIBLIOTECA E DOCUMENTAÇẪo - Campus "Luiz de Queiroz"/USP

Boza, Yolanda Eugênia Álamo Gabrine

Influência da condução da destilação sobre a composição e a qualidade sensorial da aguardente de cana / Yolanda Eugênia Álamo Gabrine Boza. - - Piracicaba, 1996.

143p. : il.

Dissertação (mestrado) - - Escola Superior de Agricultura Luiz de Queiroz, 1996.

Bibliografia.

1. Aguardente de cana-de-açúcar - Análise sensorial 2. Aguardente de cana-de-açúcar - Destilação I. Título 
INFLUÊNCIA DA CONDUÇÃO DA DESTILAÇÃO SOBRE A COMPOSIÇÃO

E A QUALIDADE SENSORIAL DA AGUARDENTE DE CANA

YOLANDA EUGÊNIA ÁLAMO GABRINE BOZA

Aprovada em 09.05.96

Comissão julgadora:

Prof. Dr Jorge Horii

ESALQ/USP

Prof. Dr. Fernando Valadares Novaes

ESALQ/USP

Prof. Dr. Clóvis Parazzi

UFSCar/Araras

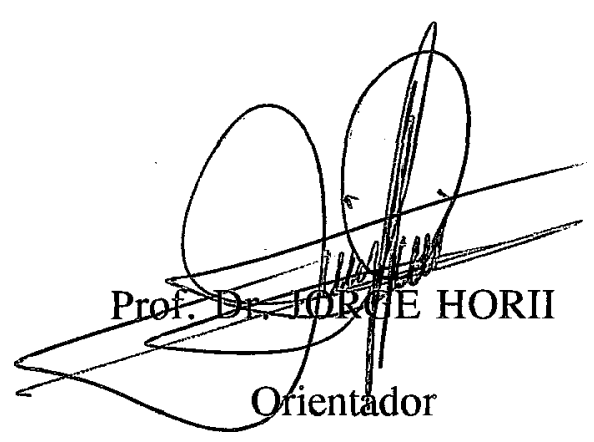


Aos meus pais Pedro e Modesta Ao Luciano e à Carolina Á tia Helena, DEDICO 


\section{AGRADECIMENTOS}

Ao Prof. Dr. Jorge Horii, por ter dado a oportunidade para a elaboração deste trabalho, pela orientação, apoio e amizade permanentes.

Aos Profs. Dr. Fernando Valadares Novaes e Dr. Luiz Eduardø Gutierrez, pelo incentivo, amizade e pelo exemplo de profissional e ser humano, em todos os momentos.

À Coordenadoria de Aperfeiçoamento de Pessoal de Nível Superior (CAPES), pela oportunidade de realização desta pesquisa.

Aos Profs. Dr. Luiz Gonzaga do Prado Filho, Dr. Arnaldo Antonio Rodella e Dra. Maria Emilia Mattiazzo-Prezotto, pelas valiosas sugestões e por cederem gentilmente as dependências dos laboratórios para a realização das análises de cobre.

Aos funcionários do Departamento de Ciência e Tecnologia Agroindustrial, em especial ao Rubens Pereira, Sylvino Torrezan, Fabio Carlet, José Emílio de Almeida, Maria Joana, Ana Flora, Silvana Albertini, Gislane Oliveira, Rosemary Mandro, Constant Christofoletti, Eduardo Giovane, Hilkias Nicolau, Carlota dos Anjos, Ivani Marchetto, Pedro Rossini, José Carlos Mendes e ao Luiz Carlos, pela colaboração sempre solícita e amiga durante o desenvolvimento deste trabalho.

Ao Prof. Dr. Décio Barbin, à Doris Gomez Ticeráu e ao Marcelo Corrêa Alves (CIAGRI), pelas valiosas sugestões e realização das análises estatísticas.

Ao Dr. Luiz Masahiro Kawaguchi da DITEC e sua equipe técnica pelo eficiente trabalho de manutenção no destilador. 
Ao Prof. Dr. Virgilio Mauricio Viana e à Lina Maria Inglês de Souza pelo valioso auxílio na obtenção de material bibliográfico.

Ao Prof. Dr. João Nunes Nogueira pelas importantes sugestões e orientação na análise sensorial.

Ao Prof. Dr. Antonio Joaquim de Oliveira e à Vera Quecini, pelo auxílio na confecção do Summary e pela amizade.

À Clotilde Maria Batochio Cunha, pela decisiva colaboração, sempre solícita e amiga no trabalho de digitação.

Ao Silvio Lucatti (Cometa) funcionário do Departamento de Química, aos funcionários José Francisco Jr. e Elaine Carboni do Departamento de Zoologia e ao Juarez Amaral do Departamento de Engenharia Rural, pela inestimável colaboração.

Ao Dr. Leo Zimback (Estação Experimental de Piracicaba-IAC) e ao Prof. Dr. Gil Miguel de Souza Câmara, pelo fornecimento de cana-de-açúcar, indispensáveis à realização desta tese.

Ao Corpo Docente da ESALQ/USP pelos ensinamentos ministrados, em especial aos professores José Otávio Brito, Murilo Melo, Marisa A.B. Regitano d'Arce, Silene Sarmento, Marco Antonio Azeredo Cesar, Nadir Almeida da Glória, Marilia Oetterer-Andrade, Roberto Bovi, Arquimedes Lavorenti, Cássio Roberto de Melo Godoi e Urgel de Almeida Lima.

Aos colegas Ana Helena Stefanovitz, Cristiano e Fabiana Siqueira, pela colaboração durante o desenvolvimento deste trabalho. 
Ao Denilson Camargo, pelo auxílio na elaboração das tabelas e gráficos.

Aos colegas Marcos Cabral Barretto, Wilson Macchi, Fernando Scardua, Vera Quecini, Kátia Tabai, Gilberto Ken-iti Yokomizo e Antonio de Goes, pelo companheirismo e apoio.

Aos funcionários da Biblioteca Beatriz Helena Giongo, Midiam Gustinelli, Eliana Maria Garcia Sabino, Kátia Maria de Andrade Ferraz, Fátima Santos Possato e Ronaldo A. Caprecci, pelas informações recebidas e pela atenção demonstrada.

À Rosa e Nivaldo Hernandez, pelo auxílio na obtenção de material bibiliográfico.

E a todos aqueles que, por meio de atitudes ou palavras de incentivo, contribuíram para que esse trabalho chegasse a termo. 


\section{SUMÁRIO}

LISTA DE TABELAS...................................................

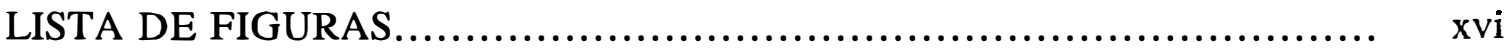

RESUMO...................................................................

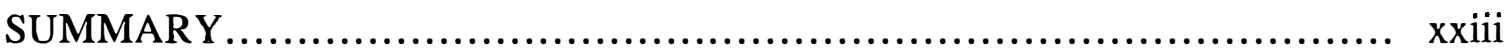

1. INTRODUÇÃ O........................................................ 1

2. REVISÃO DE LITERATURA......................................... 6

2.1. Principais componentes do flavor das bebidas....................... 8

2.1.1. Álcoois homólogos superiores................................ 8

2.1.2. Ésteres..................................................... 11

2.1.3. Ácidos orgânicos............................................ 13

2.1.4. Compostos carbonilos...................................... 15

2.1.5. Compostos sulfurados....................................... 16

2.2. Destilação na produção de bebidas....................................... 17

2.2.1. Alambique.................................................... 18

2.2.2. Colunas de destilação.......................................... 20

2.2.3. Influência do tratamento físico-químico dos destilados na eficiência da operação de destilação.............................. 21

2.2.4. Influência da fonte de aquecimento na eficiência da operação de destilação................................................. 23

2.3. Reações químicas durante a destilação................................. 24 
viii

2.4. Efeito da destilação de vinhos não centrifugados ou não decantados sobre as características das bebidas............................... 26

2.5. Influência do cobre na qualidade da aguardente........................ 27

3. MATERIAL E MÉTODOS............................................. 31

3.1. Fermentação...................................................... 31

3.1.1. Fermentadores................................................ 31

3.1.2. O mosto.................................................... 31

3.1.3. O inóculo................................................ 32

3.1.4. Condução da fermentação.................................... 32

3.2. Destilação...................................................... 33

3.2.1. Conjunto de destilação...................................... 33

3.2.2. Condução da destilação....................................... 35

3.2.2.1. Fracionamento do destilado.......................... 35

3.2.2.2. Natureza e composição dos vinhos.................... 36

$3.2 .2 .2 .1 . \mathrm{pH}$ inicial do vinho........................ 36

3.2.2.2.2. Células de leveduras no vinho............... 36

3.2.2.3. Remoção de compostos voláteis da matériaprima no vinho............................. 37

3.2.2.2.4. Teor alcoólico.............................. 37

3.2.2.3. Redestilação........................................... 38

3.2.2.4. Teor alcoólico, acidez e teor de cobre do destilado...... 39 
3.3. Métodos Analíticos................................................... 40

3.3.1. Vinhos.......................................................... 40

3.3.2. Aguardente................................................ $\quad 40$

3.3.2.1. Análises objetivas..................................... 40

3.3.2.2. Análise sensorial...................................... 41

3.3.2.3. Análise estatística...................................... 44

4. RESULTADOS E DISCUSSÃO............................................ 45

4.1. Influência do fracionamento do destilado.............................. 45

4.2. Influência da natureza e composição dos vinhos......................... 52

4.2.1. $\mathrm{pH}$ inicial do vinho....................................... 52

4.2.2. Células de leveduras no vinho............................... 57

4.2.3. Remoção de compostos voláteis da matéria-prima no vinho........ 62

4.2.4. Teor alcoólico do vinho......................................... 66

4.3. Efeito da redestilação sobre a qualidade da aguardente.................. 72

4.4. Comportamento do teor de cobre durante a obtenção de aguardente...... 105

4.5. Análise estatística.................................................... 111

4.5.1. Teste T..................................................... 111

4.5.2. Análise de fatores.............................................. 116

5. CONCLUSÕES...................................................... 123

REFERÊNCIAS BIBLIOGRÁFICAS.................................. 125

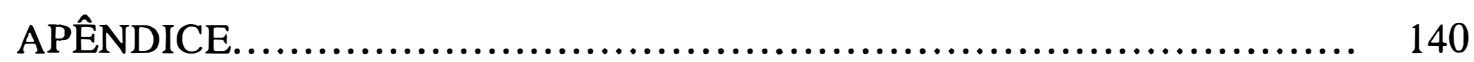




\section{LISTA DE TABELAS}

\section{TABELA}

Página

1 Evolução da produção, exportação, importação e consumo 'per capita' nacional de aguardente $(1970$ - 1985)

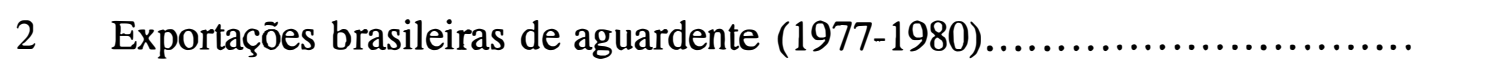

3 Análise de congêneres em rum da Jamaica (mg/100 mL etanol absoluto)... 21

4 Valores de Brix dos caldos de cana e dos mostos, teor alcoólico e acidez volátil dos vinhos.

5 Valores do teor alcoólico e volume dos destilados.

6 Acidez total, grau alcoólico e análise sensorial (média) das aguardentes....

7 Resultados das análises dos principais compostos voláteis e sensorial (média) das aguardentes.

8 Valores de Brix dos caldos de cana e dos mostos, teor alcoólico e acidez volátil dos vinhos 
9 Valores do teor alcoólico e volume dos destilados........................ 50

10 Acidez total, grau alcoólico e análise sensorial (média) das aguardentes.... 50

11 Resultados das análises dos principais compostos voláteis e sensorial (média) das aguardentes........................................... 51

12 Valores de Brix dos caldos de cana e dos mostos, teor alcoólico, acidez volátil e $\mathrm{pH}$ dos vinhos tratados com $\mathrm{Ca}(\mathrm{OH})_{2} \ldots \ldots \ldots \ldots \ldots \ldots \ldots \ldots \ldots . . \ldots \ldots$

13 Valores do teor alcoólico e volume dos destilados........................ 53

14 Acidez total, grau alcoólico e análise sensorial (média) das aguardentes.... 53

15 Resultados das análises dos principais compostos voláteis e sensorial

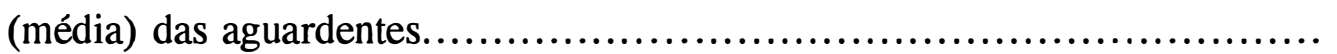

16 Valores de Brix dos caldos de cana e dos mostos, teor alcoólico, acidez

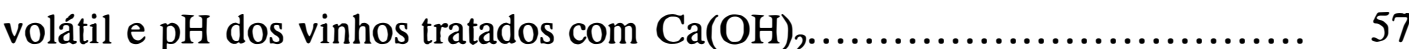

17 Valores do teor alcoólico e volume dos destilados........................ 57 
18 Acidez total, grau alcoólico e análise sensorial (média) das aguardentes.... 58

19 Resultados das análises dos principais compostos voláteis e sensorial (média) das aguardentes.

59

20 Valores de Brix dos caldos de cana e dos mostos, teor alcoólico e acidez volátil dos vinhos

21 Valores do teor alcoólico e volume dos destilados

22 Acidez total, grau alcoólico e análise sensorial (média) das aguardentes....

23 Resultados das análises dos principais compostos voláteis e sensorial (média) das aguardentes

24 Valores de Brix dos caldos de cana e dos mostos, teor alcoólico e acidez volátil dos vinhos

25 Valores do teor alcoólico e volume dos destilados

26 Acidez total, grau alcoólico e análise sensorial (média) das aguardentes.... 
27 Resultados das análises dos principais compostos voláteis e sensorial (média) das aguardentes

28 Acidez total, grau alcoólico e análise sensorial (média) das aguardentes....

29 Resultados das análises dos principais compostos voláteis e sensorial das aguardentes.

30 Valores de Brix dos mostos, teor alcoólico e acidez volátil dos vinhos.......

31 Valores do teor alcoólico e volume dos destilados obtidos na segunda destilação.

32 Acidez total, grau alcoólico e análise sensorial (média) das aguardentes...

33 Resultados das análises dos principais compostos voláteis e sensorial das aguardentes.

34 Destilação de vários constituintes durante a primeira destilação. Composição das frações sequenciais. 
xiv

34(1) Destilação de vários constituintes durante a primeira destilação. Composição das frações sequenciais (acumulada)

35 Destilação de vários constituintes durante a segunda destilação. Composição das frações sequenciais.

35(1) Destilação de vários constituintes durante a segunda destilação. Composição das frações sequenciais (acumulada)

79

36 Destilação de vários constituintes durante a segunda destilação. Composição das frações sequenciais.

96

36(1) Destilação de vários constituintes durante a segunda destilação. Composição das frações sequenciais (acumulada).

97

37 Destilação de vários constituintes da aguardente. Composição das frações sequenciais.

107

38 Composição das frações sequenciais do destilado. Teores acumulados de álcool, ácidos e de cobre. 
39 Análise sensorial das aguardentes............................... 114

40 Dados estatísticos obtidos pelo teste t............................. 115

41 Matriz de correlações entre as variáveis............................ 117

42 Cargas fatoriais de fatores e comunalidades......................... 118

43 Valores obtidos para os fatores ao nível das aguardentes............... 121 
$x v i$

\section{LISTA DE FIGURAS}

FIGURA

Página

1 Esquema do conjunto de destilação Besnard-Estève........................ 34

2 Modelo de Ficha do Teste Triangular.................................. 42

3 Modelo de ficha utilizada na avaliação sensorial das aguardentes quanto ao flavor.

43

4 Variação da concentração de etanol em função do tempo de destilação.

Primeira destilação.

81

5 Variação da concentração de etanol em função do tempo de destilação.

Segunda destilação.

82

6 Variação da concentração de acidez em função da concentração de álcool (\%v) no destilado. Primeira destilação. 
xvii

7 Variação da concentração de éster em função da concentração de álcool (\%v) no destilado. Primeira destilação

8 Variação da concentração de aldeído acético e de metanol em função da concentração de álcool (\%v) no destilado. Primeira destilação.

9 Variação da concentração de acetona em função da concentração de álcool (\%v) no destilado. Primeira destilação

10 Variação da concentração de i-amílico, i-butanol e de álcoois superiores em função da concentração de álcool (\%v) no destilado. Primeira destilação.

11 Variação da concentração de n-propanol, n-butanol e de n-amílico em função da concentração de álcool (\%v) no destilado. Primeira destilação.......

12 Variação da concentração de éster em função da concentração de álcool (\%v) no destilado. Segunda destilação

13 Variação da concentração de acidez em função da concentração de álcool (\%v) no destilado. Segunda destilação. 
xviii

14 Variação da concentração de aldeído acético e de metanol em função do concentração de álcool $(\%$ v) no destilado. Segunda destilação.

15 Variação da concentração de acetona em função da concentração de álcool (\%v) no destilado. Segunda destilação.

16 Variação da concentração de de i-amílico, i-butanol e de álcoois superiores em função da concentração de álcool (\%v) no destilado. Segunda destilação.

17 Variação da concentração de n-propanol, n-butanol e de n-amílico em função da concentração de álcool (\%v) no destilado. Segunda destilação.......

18 Variação da concentração de éster em função da concentração de álcool (\%v) no destilado. Segunda destilação.

19 Variação da concentração de acidez em função da concentração de álcool (\%v) no destilado. Segunda destilação.

20 Variação da concentração de aldeído acético e de metanol em função do concentração de álcool (\%v) no destilado. Segunda destilação. 
21 Variação da concentração de acetona em função da concentração de álcool (\%v) no destilado. Segunda destilação.

22 Variação da concentração de de i-amílico, i-butanol e de álcoois superiores em função da concentração de álcool (\%v) no destilado. Segunda destilação

23 Variação da concentração de n-propanol, n-butanol e de n-amílico em função da concentração de álcool $(\%$ v) no destilado. Segunda destilação.......

24 Variação da concentração etanol em função do tempo de destilação.

Segunda destilação 104

25 Variação da acidez total em função da concentração de etanol (\%v) do destilado

26 Variação da concentração de cobre em função da acidez total do destilado. 110

27 Valores de $\mathrm{F}_{1}$ e $\mathrm{F}_{2}$ para as aguardentes. 


\title{
INFLUÊNCIA DA CONDUÇÃO DA DESTILAÇÃO SOBRE A COMPOSIÇÃO E A QUALIDADE SENSORIAL DA AGUARDENTE DE CANA
}

\author{
Autor: YOLANDA EUGÊNIA ÁLAMO GABRINE BOZA
}

Orientador: Prof. Dr. JORGE HORII

\section{RESUMO}

O presente trabalho teve por escopo estudar a influência da condução da destilação sobre a composição e a qualidade sensorial da aguardente de cana, sendo que as destilações dos vinhos foram realizadas em aparelho de destilação tipo BesnardEstève modificado, mantendo-se constantes a velocidade e a fonte de aquecimento.

Para a obtenção dos vinhos foi utilizado caldo de cana-de-açúcar recém-cortada e submetida à moagem, filtrado e diluído com água potável até um teor de sólidos solúveis (de Brix) em torno de 14,0, com suplementação de sulfato de amônio $(0,1 \mathrm{~g} / \mathrm{L})$ e fosfato de potássio $(0,1 \mathrm{~g} / \mathrm{L})$. As fermentações foram conduzidas com fermento prensado comercial, na concentração de $3 \mathrm{~g} / \mathrm{L}$ em peso seco, a $30-32^{\circ} \mathrm{C}$, sob agitação (380 rpm), em batelada e sem reciclo de células. Durante as fermentações, acompanhou-se a atenuação do ${ }^{\circ}$ Brix e, após o término destas, foram determinadas as concentrações de etanol e acidez volátil sobre as alíquotas destiladas de vinho. 
$\mathrm{Na}$ operação de destilação, foram estudadas as influências do fracionamento do destilado, da natureza e composição dos vinhos (quanto ao pH inicial do vinho, às células de levedura e à remoção de compostos voláteis da matéria-prima) e do efeito da redestilação sobre a qualidade da aguardente, bem como o efeito da composição química do destilado sobre o teor de cobre nas aguardentes. As aguardentes obtidas foram submetidas a análises físico-químicas e sensorial.

Os resultados analíticos das aguardentes foram avaliados inicialmente a partir das informações que cada tipo de análise proporciona e, em seguida, estabelecidas relações entre as análises sensorial e físico-química através da análise de fatores pelo Método dos Componentes Principais.

Foi constatada a necessidade de ampliar o número de componentes das aguardentes analisadas, para aumentar o coeficiente de correlação entre os dados analíticos e sensoriais, viabilizando a otimização no estabelecimento de parâmetros de condução da operação de destilação e das demais operações que compõem o processo de produção de aguardente. Constatou-se também que os teores de propanol e de acidez estão em contraste à qualidade sensorial do produto, sendo que cortando a destilação com produto em alto grau, reduzem-se os teores de acidez e de cobre na aguardente, e que outra opção é a bidestilação através do fracionamento do bidestilado com a remoção da fração cabeça o que reduz a acidez do produto. Porém, cabe salientar a importância do controle de acidez em operação anterior à destilação no processo de obtenção de aguardente. 
A presença de células de leveduras no vinho influi na qualidade do destilado, porém, é necessário estudo complementar quanto à porcentagem de células adequada à obtenção de um produto de melhor flavor.

Não foi possível caracterizar a influência dos compostos voláteis da matéria-prima sobre o flavor das aguardentes. 
xxiii

\title{
INFLUENCE OF DISTILLATION CONDUCTION ON THE COMPOSITION \\ AND SENSORIAL QUALITY OF SUGAR CANE BRANDY
}

\author{
Author: YOLANDA EUGÊNIA ÁLAMO GABRINE BOZA \\ Adviser: Prof. Dr. JORGE HORII
}

\section{SUMMARY}

The purpose of the actual research work was to study the influence of distillation conduction on the composition and sensorial quality of sugar cane brandy, considering that the fermented sugar cane juice distillation was carried out in a modified Besnard-Estève distillation device, under constant heating rate and source.

It was used sugar cane juice, from fresh cut sugar cane, diluted with potable water to about $14^{\circ}$ Brix (Total soluble solids) and supplemented by amonium sulphate $(0.1 \mathrm{~g} / \mathrm{L})$ and potassium phosphate $(0.1 \mathrm{~g} / \mathrm{L})$. The fermentations were carried out with commercial pressed baker's yeast at $3 \mathrm{~g} / \mathrm{L}$ dry weight at $30-32^{\circ} \mathrm{C}$, under steering $(380 \mathrm{rpm})$, without cell recycling. During the fermentations, it was followed the Brix reduction until $0^{\circ}$ Brix. Then ethanol and volatile acidity concentrations were determined on distilled beer.

In the distillation process; distilled product fractioning nature and composition of fermented sugar cane juices (related to the inicial fermented sugar cane 
xxiv

juice $\mathrm{pH}$, yeast cells and volatile substances withdraw from raw material) and effect of re-distillation influences over the brandy quality, as well as the effect of the chemical composition of the distilled product on the copper level in the brandy. The obtained brandies were chemically and sensorially analised.

The results of the brandies analyses were formerly evaluated according to each analyses features and, then, the relationships between sensorial and chemical analyses were stablished by the factors analyses with the Principal Component Method.

It was shown the need of a greater number of brandy components to be analised in order to increase the correlation coeficient between analytical and sensorial data, optimizing the setting of parameters for distillation processes and the other stages that take part in the brandy production. It was also noticed that propanol and acidity levels are in contrast to the product sensorial quality, meanwhile when the product distillation is cut in a higher degree, the acidity levels drop as well as the copper content in the brandy, and other option could be bi-distillation through the fracctioning of the bi-distilled product with head fraction withdrawal, to decrease the product acidity. However, it is worthy to stress the importance of acidity control during the fore mentioned operation in the process of brandy production.

The presence of cells in the beer has influence on the distilled product quality whoever, further works have to be done to relate the suitable cell percentage to get a better-flavored product.

It was not possible to characterize the influence of volatile chemicals from the raw-material on the brandy flavor. 


\section{INTRODUÇÃO}

A aguardente de cana, vulgarmente chamada pinga ou caninha é definida como produto alcoólico obtido pela destilação de caldo de cana (Saccharum officinarum L.) fermentado (Brasil, 1972).

O produto de fermentação do caldo de cana, recebe a designação de vinho, podendo ser destilado em vários tipos de aparelhos, sendo assim obtida a aguardente de cana, classificada como bebida fermento-destilada (Lima, 1983).

$\mathrm{Na}$ manufatura de bebidas alcoólicas fermento-destiladas, por destilação de vinhos, a operação de destilação é um dos pontos determinantes da qualidade do produto final.

Os vinhos são constituídos de álcoois e componentes não álcoois como ácidos, ésteres, compostos carbonilos, acetais, fenóis, hidrocarbonetos, compostos nitrogenados, sulfurados, açúcares e outros, sendo que esses, presentes na bebida a caracterizam bem como a qualificam (Suomalainen \& Lehtonen, 1979). Assim a condução da destilação é fundamental na obtenção de bebida de qualidade, pois promove uma mudança na proporção dos componentes não-álcoois, que formará o bouquet característico da bebida (Souza \& Llistó, 1978).

A indústria de aguardente de cana é uma das mais antigas do Brasil. Intimamente ligada à agroindústria do açúcar, a origem da bebida perde-se no tempo, no início da colonização portuguesa nas Ilhas de Cabo Verde e no Brasil (Pinga: sem ressaca da crise, 1988). Nos tempos coloniais, a aguardente era produzida nas 
fazendas, em pequenos engenhos. Atualmente, as destilarias se acham espalhadas por toda parte, constituindo um ítem importante da indústria de bebidas no Brasil, onde se estima uma produção anual média da ordem de 2,5 bilhões de litros (Almeida \& Barreto, 1971; Maia et al., 1991).

A produção de aguardente no Brasil destina-se quase totalmente ao mercado interno, onde o consumo é um hábito amplamente difundido, especialmente entre a população de baixo poder aquisitivo, visto ser uma bebida de preço relativamente baixo, paradoxalmente, a parcela de produção destinada ao mercado externo é pouco significativa. Conforme dados da Carteira do Comércio do Banco do Brasil (CACEX), o volume de exportação não chega a $0,2 \%$ do produzido (Faria \& Lourenço, 1990). Ainda que incipiente, o volume de aguardente na pauta das exportações brasileiras, atingiu um volume de vendas da ordem de 2,2 milhões de litros em 1978, o que proporcionou cerca de 900.000 dólares de divisas (Aguardente em Minas Gerais, $1982^{1}$, citado por Furtado, 1995; Tabelas 1 e 2). O Paraguai é o maior importador de aguardente do Brasil e tomando como base o ano de 1980, esse país absorveu cerca de $97 \%$ do total das exportações brasileiras do produto. Deve ser registrada a carência de dados estatísticos oficiais sobre o setor de aguardentes, dificultando, assim, maiores informações sobre o assunto (Furtado, 1995).

\footnotetext{
' AGUARDENTE EM MINAS GERAIS. Belo Horizonte, Instituto de Desenvolvimento Industrial, 1982. 89p. Apud FURTADO, S.M.B. Avaliação sensorial descritiva de aguardente de cana. Influência da composição em suas características sensoriais e correlação entre as medidas sensoriais e físicoquímicas. Campinas, 1995. 99p. Tese (Doutorado) - Faculdade de Engenharia de Alimentos, Universidade Estadual de Campinas.
} 
Tabela 1 - Evolução da produção, exportação, importação e consumo per capita nacional de aguardente (1970 - 1985).

\begin{tabular}{cccccc}
\hline \hline Ano & $\begin{array}{c}\text { População } \\
\text { brasileira } \\
(1000 \text { hab. })\end{array}$ & $\begin{array}{c}\text { Produção de } \\
\text { Aguardente } \\
(1000 \mathrm{~L})\end{array}$ & $\begin{array}{c}\text { Exportação } \\
(1000 \mathrm{~L})\end{array}$ & $\begin{array}{c}\text { Importação } \\
(1000 \mathrm{~L})\end{array}$ & $\begin{array}{c}\text { Consumo } \\
\text { per capita }\end{array}$ \\
\hline 1970 & 94.509 & 418.113 & 335 & 11 & 4,42 \\
1971 & 95.993 & 464.482 & 537 & 25 & 4,83 \\
1972 & 98.690 & 515.992 & 666 & 82 & 5,22 \\
1973 & 111.433 & 573.217 & 1.279 & 84 & 5,64 \\
1974 & 104.243 & 636.832 & 1.083 & 49 & 6,10 \\
1975 & 107.145 & 669.084 & 1.589 & 74 & 6,23 \\
1976 & 110.125 & 702.964 & 1.775 & 60 & 6,37 \\
1977 & 113.209 & 738.568 & 2.033 & 42 & 6,51 \\
1978 & 116.393 & 775.971 & 2.167 & 36 & 6,65 \\
1979 & 119.670 & 815.269 & 1.741 & - & 6,80 \\
1980 & 123.032 & 856.556 & 1.783 & - & 6,95 \\
1981 & 126.329 & 900.000 & - & 412 & $7,27^{*}$ \\
1982 & 129.715 & 964.980 & - & 151 & $7,61^{*}$ \\
1983 & 133.191 & 1.034 .652 & - & 548 & $7,96^{*}$ \\
1984 & 136.760 & 1.109 .353 & - & 29.858 & $8,33^{*}$ \\
1985 & 140.426 & 1.189 .449 & - & 35.066 & $8,72^{*}$ \\
\hline \hline
\end{tabular}

* Estimativa.

Fonte: FURTADO, 1995. 


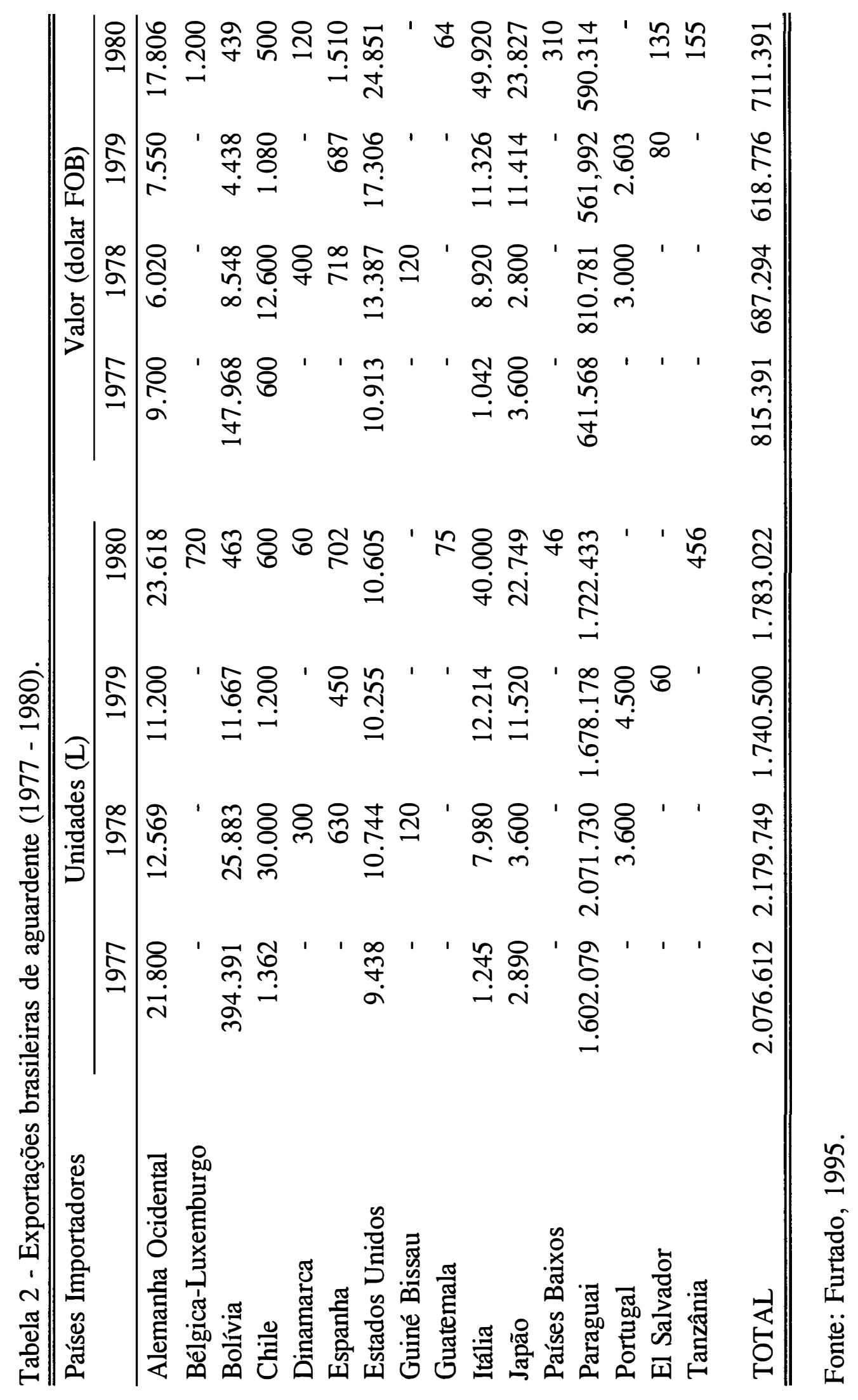


Pesquisas a nível nacional apontam que alterações na qualidade da aguardente resultariam em uma melhor acolhida do produto não só pelos consumidores, como também por parte dos atuais não consumidores, em conseqüência das mudanças conjunturais e em virtude do elevado preço das bebidas destiladas importadas, que favorece o aumento da demanda das bebidas nacionais (Lima Neto \& Franco, 1994). Portanto, a otimização das condições de obtenção da aguardente é essencial para se obter um produto de preço e padrões de qualidade competitivos, propiciando um maior espaço no mercado interno e externo de bebidas alcoólicas, representando uma considerável fonte de divisas.

A presente pesquisa apresenta uma série de dados obtidos do fracionamento do destilado em aparelho de destilação Besnard-Estève modificado, mostrando o comportamento de vários componentes álcoois e não-álcoois. Com as frações obtidas na destilação foram compostas várias aguardentes recém destiladas e submetidas a testes de preferência que foram estatisticamente analisadas.

O estudo envolveu também a análise do teor de cobre proveniente do equipamento destilatório em função da composição química da fração obtida. 


\section{REVISÃO DE LITERATURA}

O maior desafio para o tecnologista de bebidas é a definição do produto final, pois o conhecimento das substâncias responsáveis pelo flavor e por outras características das bebidas, está longe de ser elucidado; tais substâncias encontram-se em quantidades mínimas, dificultando seu isolamento, caracterização e quantificação e sem o conhecimento de tais substâncias torna-se muito difícil modificar as características ou controlar a qualidade do produto (Garrick, 1980; Daudt \& Ough, 1975).

Dentro de cada categoria de produto, há uma ampla variação de flavor, causada por: tipo de matéria prima e suas proporções; método de preparação; condições de fermentação; processo de destilação; técnicas de maturação; misturas (blending) (Packowsky, 1978; Suomalainen, 1971; Guymon, 1974).

Estudos comparativos qualitativos e quantitativos de substâncias em

diferentes bebidas alcoólicas mostram que, embora alguns compostos sejam peculiares de uma bebida particular ou tipo de bebida, em geral, os compostos que são responsáveis pelo flavor ou bouquet em bebidas, são bastante similares, independente da natureza da bebida (Nykänen et al., 1968; Suomalainen et al., 1974).

As diferentes bebidas podem ser prontamente distinguidas organolepticamente; os métodos analíticos não revelam grande diferença qualitativa 
e a maior diferença parece ser quanto a concentração das substâncias aromáticas nas diferentes bebidas (Suomalainen \& Lehtonen, 1979). Porém a contribuição de um composto ao aroma total apresentado é difícil predizer a partir da concentração presente, devido à complicadas interações de odor, em especial a alteração do threshold de odor em presença de etanol (Williams, 1972, citado por Williams \& Rosser, 1981)2. O problema se torna mais complexo em virtude de alguns compostos apresentarem um baixíssimo threshold, de difícil determinação quantitativa, fazendo com que a taxação acurada de sua contribuição ao aroma final da bebida, seja praticamente impossível (Webb \& Muller, 1972).

A origem metabólica das substâncias aromáticas presentes nas bebidas alcoólicas, tem sido objeto de estudos intensivos por muitos anos. Alguns compostos organolepticamente importantes estão presentes no extrato da matéria-prima usada na manufatura da bebida, que podem permanecer inalterados durante a fermentação, outros compostos do extrato podem ser modificados quimicamente pela levedura ou durante a destilação, originando compostos que influenciam no flavor do produto. Durante a fermentação as leveduras excretam compostos, os quais são organolepticamente desejáveis e finalmente podem surgir outros compostos, oriundos da estocagem (Rose, 1977) e do envelhecimento (Almeida et al., 1947).

Os compostos responsáveis pelo flavor das bebidas são constituídos principalmente por álcoois, ácidos graxos e ésteres denominados componentes nãoálcoois (não-etanol) (Almeida \& Barreto, 1971) ou ainda congêneres, no caso de bebida fermento-destilada (Packowski, 1978).

\footnotetext{
${ }^{2}$ WILLIAMS, A.A. Flavour effects of ethanol in alcoholic beverages. Flavour Industry, v.3, n.12, p.604-607, 1972 Apud WILLIAMS, A.A. \& ROSSER, P.R. Aroma enhancing effects of ethanol. Chemical Senses, v.6, n.2, p.149-153, 1981.
} 


\subsection{Principais componentes do flavor das bebidas}

\subsection{1. Álcoois superiores}

Nas bebidas destiladas, os álcoois superiores são o maior grupo entre os componentes do aroma, sob o aspecto quantitativo, sendo que em média, o rum contém 0,6 g/L, o uisque escocês $1 \mathrm{~g} / \mathrm{L}$ e $\mathrm{o}$ conhaque cerca de $1,5 \mathrm{~g} / \mathrm{L}$ (Suomalainen, 1971). Esses álcoois denominados também de óleo fúsel, tem um significante efeito sobre as características sensoriais das bebidas, sendo que o 1 propanol, o isobutanol, o amílico e o isoamílico são importantes componentes do uísque e vinhos, porém, altas concentrações desses, podem conferir odor desagradável para o brandy, sendo sugerido o limite de óleo fúsel entre 60 a 120 g/100 litros à 50\% v/v de álcool (Zee et al., 1984).

O álcool isoamílico é o principal álcool sintetizado durante a fermentação, dependendo da natureza da bebida pode perfazer $40-70 \%$ do total de óleo fúsel; outros importantes são o n-propílico, isobutílico e amílico opticamente ativo (Suomalainen \& Lehtonen, 1979), além do butanol e pentanol, também encontrados em bebidas destiladas (Rose, 1977).

Os álcoois superiores são subproduto de síntese de aminoácidos e proteínas nas leveduras; opostamente aos ésteres, a síntese de álcoois superiores é estimulada por oxigênio, e sua síntese está relacionada linearmente ao crescimento da levedura. A síntese de álcoois superiores constitui uma das rotas pela qual as células das leveduras modulam seu balanço redox; assim, há uma relação linear entre 
a síntese de álcoois superiores e glicerol (Quain, 1988). Os álcoois superiores são também formados, como produtos secundários do metabolismo de carboidratos (Ylänen, 1966, citado por Askew \& Lisle, 1971).

Os fatores que influenciam os níveis de álcoois superiores durante a fermentação são: a matéria-prima, a linhagem da levedura, o pH do meio de fermentação, a concentração inicial do inóculo, a temperatura de fermentação, a aeração, a matéria suspensa, a quantidade e a natureza dos nutrientes presentes no mosto e a presença de microrganismos contaminantes (Guymon, 1974; Margalith \& Schwartz, 1970; Gutierrez, 1993; Godoy, 1992; Simpson, 1971; Manitto et al., 1994; Äyräpää, 19684, citado por Rose, 1977; Ramsay \& Berry, 1984).

A destilação é outra operação no processamento de destilados, a qual pode controlar a concentração de álcoois superiores. A concentração de álcoois superiores dá informação sobre o tipo de destilação empregada, por exemplo, o malt whisky, processo pot still, apresenta todos os álcoois superiores no destilado (n-propanol, isobutanol, isoamílico), enquanto o grain whisky, processo de destilação contínua Patent Still (ou Coffey) remove a maior parte do álcool isoamílico e outros congêneres menos voláteis (Aylott et al., 1987).

Os álcoois superiores estão presentes inevitavelmente, em bebidas destiladas devido as suas propriedades físicas em relação ao álcool etílico e a água. As técnicas de separação/extração de óleo fúsel removem a maioria dos flavores

${ }^{3}$ YLÄNEN, L. Journal of the Institute of Brewing, v.72, p.50, 1966, Apud ASKEW, B. \& LISLE, D.B. Variation in the concentrations of higher alcohols, methanol and ethyl acetate in brandies. Journal of the Science of Food and Agriculture, v.22, p. 102-104, 1971.

4 ÄYRÄPÄÄ, T. Journal of the Institute of Brewing, v.74, p.169, 1968, Apud ROSE, A.H. Alcoholic Beverages, Academic Press, 1977, cap.9 (Economic Microbiology, 1). 
naturais, sendo essa a fundamental razão pela qual se estabelece o proof de destilação, no caso do brandy $170^{\circ}$ proof, pois assegura que o destilado mantenha o flavor e aroma característicos (Guymon, 1972).

Os álcoois superiores conferem corpo à bebida, além de alguns esterificarem durante o envelhecimento e seus ésteres são aromaticamente mais agradáveis. A faixa de concentração de óleo fúsel em brandies é de 60 a 120 g por $100 \mathrm{~L}$ à $100^{\circ}$ proof, sendo classificados como: light-bodied $(60-70 \mathrm{~g} / 100 \mathrm{~L})$, medium-bodied (75-90 g/100 L) e heavy-bodied (90-100 g/100 L) (Guymon, 1972).

Segundo Lima (1964) a aguardente de cana fabricada em alambique, quase sempre sem retificadores, consequentemente sem separação do óleo fúsel, apresenta uma riqueza em óleo fúsel muito elevada, parecendo ser esta um fator de qualidade das aguardentes. Almeida \& Barreto (1971), verificaram que aguardentes classificadas por suas características sensoriais como de qualidade inferior, contêm um teor de n-propanol elevado em relação aos outros álcoois presentes, enquanto as consideradas de boa qualidade continham apenas n-propanol, isobutanol e isoamílico. Amerine et al. (1972) sugerem que os álcoois superiores podem não ser apenas importantes devido ao seu odor característico, mas também devido sua ação solvente sobre outras substâncias aromáticas, interferindo no grau de volatilidade.

Os álcoois superiores normalmente devem acompanhar proporcionalmente os ésteres, numa aguardente de boa qualidade, onde a relação álcool/éster não deve se afastar muito da unidade, estando entre 1 e 2 (Souza \& Llistó, 1978; Lima, 1964). 
Almeida et al. (1947), estabeleceram, para efeito comparativo os seguintes coeficientes de julgamento, para se determinar a qualidade das aguardentes, levando em conta, tão somente a relação álcool/ésteres.

$\begin{array}{lll}\text { menos de } 0,5 & - & \text { inferior } \\ \text { de } 0,5 \text { a } 0,7 & - & \text { boa } \\ \text { de } 0,7 \text { a } 0,9 & - & \text { muito boa } \\ \text { de } 0,9 \text { a } 1,1 & - & \text { ótima } \\ \text { de } 1,1 \text { a } 1,3 & - & \text { muito boa } \\ \text { de } 1,3 \text { a } 1,5 & - & \text { boa } \\ \text { mais de } 1,5 & - & \text { inferior }\end{array}$

\subsection{2. Ésteres}

Os ésteres são numericamente, o maior grupo de componentes do aroma das bebidas destiladas, seus threshold sensorial são muito baixos e conferem flavores característicos, até mesmo quando presentes em baixa concentração, porém a composição qualitativa dos ésteres é altamente similar em todas as bebidas alcoólicas (Suomalainen, 1981). A formação de ésteres é principalmente devido à atividade metabólica, enquanto a esterificação química contribui apenas em pequena extensão, sendo a maior parte dos ésteres constituída por ésteres etila de ácidos graxos (Samarajeewa et al., 1981; Suomalainen, 1971).

A biossíntese de ésteres aumenta quando a divisão celular cessa, pois a biossíntese de lipídeos e ésteres envolve um intermediário comum, a acetil-coenzima A (Acetil-CoA), intermediário de alta energia, produzido durante a fermentação ativa pela ação da acetil-CoA sintetase sobre o ácido acético e a coenzima A (CoASH). 
Com a interrupção da biossíntese de lipídeos, aumenta a disponibilidade de acetilCoA, aumentando a velocidade de formação de ésteres (Garrick, 1980; Quain, 1988). Assim, há vários fatores que influenciam na concentração de ésteres no vinho, como: nível de oxigênio; temperatura e pH de fermentação; linhagem da levedura (Killian \& Ough, 1979; Nykãnen \& Nykãnen, 1977; Ramsay \& Berry, 1984).

Os ésteres, de modo geral são desejáveis, pois favorecem o aroma da aguardente, sendo oriundos da fermentação, da destilação e do envelhecimento (Amerine et al., 1972; Simpson, 1971).

O aroma dos ésteres é mais acentuado quando o álcool que os compõem é de baixo peso molecular (por exemplo, o álcool etílico). Além disso, cada éster tem um aroma peculiar. Os acetatos de etila e de butila apresentam aroma frutado, o acetato de isoamila e o butirato de amila tem aroma de banana, enquanto os acetatos de álcoois maiores tem aroma cítrico, porém, menos pungente que os ésteres de álcoois menores (Rigott, 19895 , citado por Maia, 1994). Llistó et al. (1979) verificaram a presença de acetato de butila, acetato de etila, butirato de etila e acetato de isoamila em 11 marcas de aguardente de cana, enquanto MURTA et al. (1982) encontraram etanoatos de metila, etila e de isopentila em aguardentes comerciais.

O acetato de etila que corresponde a cerca de $80 \%$ do conteúdo total de ésteres da aguardente, éster formado durante a fermentação e na destilação, como produto de reação de esterificação entre álcool etílico e ácido acético, confere odor

\footnotetext{
s RIG0TT, J.R. (Ed.). Distilled Beverage Flavour. Weinheim: VCA, 1989, Apud MAIA, A.B. Componentes secundários da aguardente, STAB, v.12, n.6, p.29-34, 1994.
} 
e gosto desagradável, sendo um dos componentes indesejáveis, cujo threshold de odor está situado em torno de $200 \mathrm{mg} /$ litro (Hashizume, 1976).

As aguardentes consideradas de qualidade inferior apresentam grande predominância de ésteres em relação aos álcoois superiores, nessas a relação álcool/éster é sempre inferior à unidade (Souza \& Llistó, 1978).

\subsection{3. Ácidos orgânicos}

Os ácidos orgânicos voláteis são os mais comuns em bebidas destiladas, sendo o ácido acético o mais abundante (Rose, 1977). Os ácidos alifáticos de cadeia não ramificada e seus ésteres de etila, constituem o segundo grupo mais abundante de componentes não-álcoois encontrados em bebidas destiladas (Guymon, 1974).

O conteúdo de ácidos em bebidas alcoólicas pode variar consideravelmente, no uísque escocês é cerca de $100 \mathrm{mg} / \mathrm{litro}$; no conhaque aproximadamente $200 \mathrm{mg} / \mathrm{litro}$, enquanto o rum da Martinica pode conter até 600 $\mathrm{mg} /$ litro. As leveduras sintetizam praticamente os mesmos ácidos, independente da natureza do substrato, sendo que os ácidos caprílico e cáprico, são os maiores componentes do rum, uísque escocês e conhaque, em proporções relativas bastante similares, salvo alguma exceção. Portanto as proporções dos compostos no vinho, são determinadas em grande extensão pela linhagem da levedura e condições de fermentação e, em menor extensão, pelo substrato (Nykänen et al., 1968; Suomalainen \& Lehtonen, 1979). 
Os ácidos sintetizados pelas leveduras, no meio de fermentação, são os mesmos da fração lipídica das células de leveduras (Suomalainen, 1971). Esses ácidos podem prontamente passar da célula da levedura para o meio durante a fermentação, onde através de reações de esterificação produzem seus respectivos ésteres de etila (Suomalainen \& Nurminen, 1976; Suomalainen et al., 1974). A composição de ácidos graxos da levedura é influenciada pelas condições de fermentação, como: presença de oxigênio, temperatura de fermentação e suplementação do meio (Taylor \& Kirsop, 1977; Suomalainen \& Lehtonen, 1979; Rosi \& Bertuccioli, 1992).

Os ácidos orgânicos voláteis indubitavelmente contribuem para o flavor das bebidas destiladas, devido ao seu flavor característico, pois são capazes de aumentar a acidez, apenas em pouca extensão. O ácido acético é o predominante, sendo que sua concentração varia amplamente em diferentes bebidas destiladas, porém, na maioria dos casos corresponde de 60 a $95 \%$ da acidez total (Nykänen \& Nykänen, 1991).

Nóbrega (1994) analisando a acidez volátil em aguardentes de cana comerciais, incluindo aguardentes representativas dos três principais Estados produtores (SP, MG e CE), verificou que o valor máximo de acidez volátil permitido pela legislação $(0,150 \mathrm{~g} / 100 \mathrm{~mL}$ de álcool anidro) é bem superior aos valores médios verificados para todas as aguardentes analisadas, portanto, o padrão estabelecido para acidez volátil não está em sintonia com processos de fabricação e, em última análise, permite que se ponha no mercado um produto excessivamente ácido. 


\subsubsection{Compostos carbonilos}

Os compostos carbonilos são um dos principais componentes responsáveis pelo flavor das bebidas, particularmente os aldeídos, pois um grande número desses apresentam baixo valor de threshold sensorial (Rose, 1977; Almeida \& Barreto, 1973).

A maioria dos aldeídos em bebidas alcoólicas, são formados durante a fermentação, sendo produtos intermediários da rota biossintética de álcoois superiores, formados por descarboxilação de $\alpha$-cetoácidos pela piruvato descarboxilase (Suomalainen \& Lehtonen, 1979).

O acetaldeído é o composto predominante em bebidas destiladas, representando $90 \%$ da concentração total de aldeídos em whisky, cognac e rum (Nykänen \& Nykänen, 1991). O acetaldeído é importante à composição do aroma das bebidas, devido ao seu baixo threshold sensorial, sendo também formado durante a destilação por oxidação do álcool etílico (Amerine et al., 1972). Andrade \& Bravo (1989), analisando amostras de aguardentes de cana comerciais detectaram a presença de formaldeído e acetaldeído em concentrações (ppm) 0,69, 0,40; 62,98, 28,7 máximas e mínimas, respectivamente.

Aldeídos insaturados têm sido encontrados em bebidas destiladas como o 2-propenal (acroleína) oriundo da ação de bactérias sobre o glicerol ou da desidratação do glicerol sobre as superfícies quentes da coluna de destilação. A acroleína tem odor pungente e propriedades lacrimejantes (Williams \& Strauss, 1975; Suomalainen \& Nykänen, 1970). 
A diacetildiona e em menor extensão a 2,3-pentadiona são importantes compostos na composição das características sensoriais das bebidas destiladas (Rose, 1977; Garrick, 1980; Whiting, 1976).

\subsubsection{Compostos sulfurados}

Os compostos sulfurados tem baixo threshold de odor, assim apresentam efeito marcante sobre o aroma, cuja ocorrência é de primária importância na avaliação sensorial. Dellweg et al. (1969) ${ }^{6}$ citados por Suomalainen \& Lehtonen (1979), identificaram vários compostos em bebidas destiladas, incluindo dietilsulfeto, dimetil-dissulfeto e etil-metil-sulfeto e demonstraram que os compostos sulfurados são produtos da autólise de aminoácidos sulfurados da fração protéica das leveduras, durante a fermentação, onde a volatilidade dos compostos sulfurados assegura, que eles sejam largamente eliminados dos mostos por arraste de $\mathrm{CO}_{2}$, porém na fase secundária da fermentação a eliminação ocorre mais lentamente.

As leveduras exibem uma considerável variação na habilidade de formar sulfeto de hidrogênio durante a fermentação (Dott et al., 1976) e o seu controle na manufatura de bebidas alcoólicas é altamente importante, pois o sulfeto de hidrogênio $\left(\mathrm{H}_{2} \mathrm{~S}\right)$ e os compostos formados a partir dele, podem ser produzidos em quantidades que depreciam o produto, embora nas bebidas destiladas sejam de menor importância, pois a maioria é removida durante a destilação (Wainwright, 1971). O

\footnotetext{
${ }^{6}$ DELLWEG, H.; MIGLIO, G.; NIEFIND, H.-J. Branntweinwirtschaft, v.109, p.445, 1969. Apud SUOMALAINEN, H. \& LEHTONEN, M. The production of aroma compounds by yeast. Journal of the Institute of Brewing, v.85, n.3, p.149-156, 1979.
} 
sulfeto de hidrogênio pode reagir com o etanol durante a destilação produzindo etanoditiol, que pode ser prontamente oxidado por $\mathrm{O}_{2}$ atmosférico, a dietil-dissulfeto, composto de odor altamente desagradável (Margalith \& Schwartz, 1970).

\subsection{Destilação na produção de bebidas}

A destilação é uma técnica muito antiga, usada pelos Chineses 3000 anos A.C., sendo que inicialmente, o líquido produzido, denominado alcohol pelos árabes, era utilizado para fins medicinais e na produção de perfumes. Os árabes, durante a invasão da Europa no século VI, difundiram a técnica de destilação, que foi progressivamente melhorada quanto à técnica e equipamentos de destilação por monges e alquimistas. Arnouldus Villanouus (1235-1315), na França, foi o primeiro que adaptou das escrituras árabes, a palavra alcohol e descreveu a destilação de vinho, a qual obteve um produto que ele denominou eau-de-vie ou água da vida (CONSIDERAÇÃO histórica em torno dos destilados, 1978; Leauté, 1990).

$\mathrm{Na}$ manufatura de bebidas alcoólicas destiladas, a destilação separa, seleciona e concentra pelo uso do calor a fração dos componentes oriundos da fermentação do mosto; assim, a composição das bebidas depende em grande extensão da forma pela qual é conduzida a destilação (Suomalainen, 1971; Suomalainen \& Nykänen, 1966).

Há um grande número de tipos de aparelhos destilatórios disponíveis, oferecendo uma ampla faixa de flexibilidade para o refinamento das bebidas destiladas, sendo os mais difundidos o alambique e a coluna contínua. 


\subsubsection{Alambique}

A palavra alambique é originária da palavra grega Ambix, definida como um vaso com pequena abertura. No alambique efetuam-se duas destilações do vinho, sendo originalmente realizada no mesmo corpo, porém, com o objetivo de minimizar o nível de impurezas e aumentar a produtividade da operação, o método foi aperfeiçoado utilizando 2 corpos, sendo denominado o primeiro corpo, wash still ou caldeira de esgotamento e o segundo, low wines still ou caldeira de destilação, e a técnica denominada dupla destilação. O vinho é aquecido no wash still, produzindo vapores, parte deles alcança o capitel ou chapiteau, onde ocorre o processo de refluxo, isto é, processo de seleção dos componentes voláteis, sendo que parte desses são condensados retornando ao wash still, enquanto as substâncias mais voláteis são conduzidas através do Swan's neck ou alonga, para a serpentina da caldeira de destilação onde o vinho se enriquece de substâncias mais voláteis e se aquece, ocorrendo a segunda destilação. A primeira destilação do vinho procede até o destilado conter um teor alcoólico de $20 \%$, esses são redestilados no low wines still até resultar num destilado, cujo teor alcoólico varia de 35-60\% dependendo do tipo da bebida (Hirsch, 1937).

Os vinhos contém um grande número de compostos voláteis que destilam, segundo três critérios: ponto de ebulição, afinidade com álcool, água e teor alcoólico no vapor durante a destilação (Léauté, 1990), sendo que em função do grau de volatilidade, o destilado é dividido em três frações: cabeça, coração e cauda (Suomalainen \& Nykänen, 1966). 
Segundo Léauté (1990), no caso da primeira destilação em alambique, os compostos voláteis recebem a seguinte classificação:

Tipo 1 - Componentes solúveis em álcool, com baixo ponto de ebulição, destilam no início da destilação, apresentando-se em altas concentrações na cabeça e no início do coração. Ex: Acetaldeido PE $21^{\circ} \mathrm{C}\left(69,8^{\circ} \mathrm{F}\right)$; acetato de etila PE $77^{\circ} \mathrm{C}\left(170,6^{\circ} \mathrm{F}\right)$.

Tipo 2 - Componentes que apresentam relativamente alto ponto de ebulição e são total ou parcialmente solúveis em etanol. Alguns desses compostos terminam de destilar no meio do coração. Ácidos graxos e seus ésteres estão nessa categoria.

Tipo 3 - Componentes que apresentam baixo ponto de ebulição $\left(\leq 200^{\circ} \mathrm{F}\right)$, solúveis em álcool e total ou parcialmente solúveis em água, encontram-se na cabeça e no coração do destilado. Metanol e álcoois superiores (1propanol, isobutanol, metil-2-butanol e metil-3-butanol).

Tipo 4 - Componentes que apresentam ponto de ebulição maior que o de água, solúveis ou parcialmente solúveis em água, iniciando a destilação no meio do coração. Ácido acético PE $110^{\circ} \mathrm{C}\left(230^{\circ} \mathrm{F}\right)$, lactato de etila, 2feniletanol.

Tipo 5 - Componentes que apresentam um alto ponto de ebulição são muito solúveis em água e são produzidos durante a destilação. Ex: furfural $\mathrm{PE} 167^{\circ} \mathrm{C}$, cuja concentração aumenta do meio do coração para cauda. 
Na primeira destilação de cognac, Lafon et al. (1964) ${ }^{7}$ citados por Amerine et al. (1972), verificaram que os componentes não-álcoois, destilam quando a percentagem de álcool no destilado é acima de 50\%, exceto os álcoois superiores, que continuam à destilar em quantias apreciáveis até a percentagem de álcool alcançar em torno de $30 \%$. Porém, o furfural aparece no destilado cujo teor de álcool é em torno de $40 \%$ e continua destilar abaixo de $25 \%$. Na segunda destilação, o comportamento dos componentes voláteis é levemente diferenciado, devido o aumento do conteúdo de álcool na fração coração (Léauté, 1990).

\subsubsection{Colunas de destilação}

A coluna consiste em uma forma de alambiques interconectados em série, de operação contínua; é de fácil manejo, consome menos combustível, requer mãode-obra menos hábil, permite maior produtividade e uniformidade do produto (Lima, 1964).

Guymon $(1949)^{8}$, citado por Amerine et al. (1972) demonstrou que há pouca diferença analítica entre os destilados obtidos em coluna e alambique, porém, são prontamente distinguidos por análise sensorial e argumenta que se a lenta destilação em alambique não contribuisse singularmente para o caráter da bebida, provavelmente esse procedimento não teria sobrevivido na região de Cognac.

\footnotetext{
${ }^{7}$ LAFON, R.; LAFON, J. and COUILLAUD, P. Le cognac, la destillation. J.B. Baillière et Fils, Paris, 1964. Apud AMERINE, M.A.; BERG, H.W.; CRUESS, W.V. The tecnology of wine making. 3.ed., Westport, The AVI PUBL., 1972. cap. 17.

${ }^{8}$ GUYMON, J.F. Composition of brandy, investigation of the influence of distillation practices upon the composition of brandies. Wines \& Vines, v.30, n.10, p.21-24, 1949. Apud AMERINE, M.A.; BERG, H.W.; CRUESS, W.V. The technology of wine making. 3.ed., Westport, The AVI PUBL., 1972, cap.17.
} 
Segundo Reed \& Nagodawithana (1991), o efeito da destilação sobre o flavor e o odor da bebida, pode ser drástico através da remoção quantitativa das frações cauda e cabeça durante a destilação. L'Anson $(1971)^{9}$ citado por Reed \& Nagodawithana (1991), demonstrou que a coluna contínua tem maior capacidade em remover congêneres de maior e menor ponto de ebulição, conforme Tabela 3 . Assim, a concentração de congêneres nas bebidas pode ser manipulada pelo tipo e operação do aparelho destilador.

Tabela 3 - Análise de congêneres em rum da Jamaica ( $\mathrm{mg} / 100 \mathrm{~mL}$ etanol absoluto)

\begin{tabular}{cccc}
\hline \hline & Pot Still & Medium Continuous & $\begin{array}{c}\text { Very Light } \\
\text { Continuous Still Rum }\end{array}$ \\
\hline Rum & Still Rum & 4,1 \\
Ésteres & 120,0 & 49,0 & 0,4 \\
Aldeídos & 16,0 & 32,1 & 1,1 \\
Álcoois Superiores & 290,0 & 117,0 & 1,0 \\
\hline \hline
\end{tabular}

\subsubsection{Influência do tratamento físico-químico dos destilados na eficiência da operação de destilação}

Segundo Williams \& Strauss (1976), na manufatura de bebidas alcoólicas a partir da destilação de vinhos, as impurezas de baixo ponto de ebulição são coletadas na fração conhecida como cabeça. Essa fração tem um volume de 5 a $15 \%$ do produto, dependendo do tipo e condições de destilação, e possui teor alcoólico

\footnotetext{
${ }^{9}$ L'ANSON, J.A.P. Rum Manufacture. Proc. Biochem., v.6, n.7, p.35-39, 1971. Apud REED, G. \& NAGODAWITHANA, T.W. Distiller's Yeast. In: Yeast Technology, 2.ed. New York, AVI Book, 1991. cap.5.
} 
mínimo de $80 \%$, além de compostos altamente indesejáveis como acetaldeído, acetato de etila e 1,1-dietoxietano, bem como dióxido de enxofre e seus derivados, caso tenha sido usado na preparação do mosto. Em virtude da alta percentagem de etanol, presente na fração cabeça, vários procedimentos visando seu aproveitamento têm sido sugeridos. Uma das técnicas exaustivamente utilizadas, a redestilação das frações cabeça em coluna de retificação origina bebida de qualidade inferior.

Lucena (1957) recomenda para se obter uma aguardente de boa qualidade, a adoção da seguinte prática: a fração cabeça é separada quando o alcoômetro marcar 80 a $85^{\circ} \mathrm{GL}$ em seguida destila o coração de 80 a $85^{\circ} \mathrm{GL}$ à $45^{\circ} \mathrm{GL}$, originando um produto com uma riqueza alcoólica média de 55 a $65^{\circ} \mathrm{GL}$, e finalmente a cauda, sendo que os produtos extremos são adicionados na destilação da próxima batelada de vinho. Segundo Léauté (1990), procedimento semelhante é utilizado na região de Cognac, da primeira destilação originam três frações: cauda, coração e cabeça; as frações cabeça e a cauda são redestiladas com a batelada posterior enquanto a fração coração é usada na segunda destilação bonne chauffe, que dá origem a 4 frações: cabeça, coração (1) (cognac), coração (2) e cauda. A cabeça e a cauda são incorporadas à bateladas de vinho subsequentes e a fração coração (2) é redestilada juntamente com o coração proveniente da primeira destilação.

Williams \& Strauss (1976) obtiveram bons resultados no tratamento da fração cabeça de destilados de vinho de uva, através da destilação, com processo diferencial de temperatura de condensação, cujas frações foram previamente diluídas e acidificadas, para propiciar hidrólise de acetais e aumentar a volatilidade do acetaldeído, utilizando aspersão com gás inerte $\left(\mathrm{N}_{2}\right)$ na entrada do condensador com 
o objetivo de aumentar a velocidade e eficiência da operação, quanto a remoção de acetaldeído e dióxido de enxofre, e quando a concentração desses componentes caiu para níveis mínimos a fração foi basificada para propiciar remoção de acetato de etila e em seguida destilada sem aspersão.

\subsubsection{Influência da fonte de aquecimento na eficiência da operação de destilação}

A natureza da fonte de aquecimento é importante não apenas pelo uso racional de energia, como também pela influência na qualidade das aguardentes. Os produtos obtidos sobre fogo direto são muitas vezes mais aromáticos, contendo alto teor de álcoois superiores e furfural, devido a super aquecimentos locais, com carbonização mais ou menos intensa da matéria orgânica (Chaminade, 1930 citado por Lima, 1964).

Almeida (1952), verificou que o uso de aquecimento a vapor, origina aguardente de boa qualidade se a destilação for conduzida lentamente.

Pacottet \& Guittonneau (1922) ${ }^{11}$ citados por Lima (1964) observaram que no aquecimento a fogo direto, a lenha é preferida ao carvão e ao óleo, porque é mais irregular na distribuição de calor desenvolvido pela combustão.

${ }^{10}$ CHAMINADE, R. La production et le commerce des eaux-de-vie de vin. Paris, Libr. J.B. BAILLIÈRE \& FILS, p.33-4/48/69, 1930. Apud LIMA, U. de A. Estudos dos principais fatores que afetam os componentes do coeficiente não-álcool das aguardentes de cana. Piracicaba, 1964. 141p. (Cátedra) - Escola Superior de Agricultura "Luiz de Queiroz", Universidade de São Paulo.

"PACOTTET, P. \& GUITTONNEAU. Aguardientes y vinagres. Ilustr., Barcelona, Casa P. Salvat, p.205-16/252/339-40, 1922. Apud LIMA, U.de A. Estudos dos principais fatores que afetam os componentes do coeficiente não-álcool das aguardentes de cana. Piracicaba, 1964. 14lp. (Cátedra) -Escola Superior de Agricultura "Luiz de Queiroz", Universidade de São Paulo. 
O emprego de aquecimento direto pelo uso de gás de rua engarrafado ou gasolina, na destilação de aguardente, oferece produto de ótima qualidade, devido a lentidão da operação (Lima, 1964). Segundo Léauté (1990), os gases mais comumente utilizados na produção de cognac, no aquecimento direto são propano, butano e gás natural, onde obtêm-se temperatura de $1400^{\circ} \mathrm{F}$ a $1600^{\circ} \mathrm{F}$, ideais para produzir aromas durante a destilação.

Lima (1964) verificou que as aguardentes resultantes de destilação cujo aquecimento é fogo direto, independente da fonte de calor, apresentam maior concentração de furfural.

\subsection{Reações químicas durante a destilação}

As condições sob as quais é conduzida a destilação é de primordial importância às características da bebida, pois além de afetar as quantidades relativas dos componentes não-álcoois, promove algumas reações químicas induzidas pelo calor (Guymon, 1974), dependendo do tipo de reação, os componentes voláteis do vinho podem aumentar ou diminuir e ainda originar novos componentes (Léauté, 1990).

Algumas reações são conhecidas há anos como hidrólise, esterificação, acetalização, produção de furfural e reações com cobre. Segundo Guymon (1974) a esterificação direta pode ocorrer sobre os pratos da coluna de destilação onde os álcoois e ácidos estão mais concentrados.

Os acetais são muito comuns em bebidas destiladas, sendo produto da condensação de compostos carbonilos e álcool, durante a destilação. A acetalização é catalizada por íons hidrogênio, sendo que, a baixo $\mathrm{pH}$, o equilíbrio é rapidamente estabelecido, e o grau de acetalização dependerá da concentração de etanol e de água 
(Guymon, 1974). A formação de acetais reduz a concentração de aldeídos livres no destilado suavizando o odor pungente causado pelos aldeídos (Williams \& Strauss, 1975).

A reação de Maillard é uma reação importante que pode ocorrer durante a destilação, sendo a principal fonte de compostos heterocíclicos como furanos, pirazinas e piridinas (Léauté, 1990).

A fração cabeça pode ser altamente ácida e corrosiva, se dióxido de enxofre ou bissulfito estiverem presentes no vinho, pois estes compostos podem reagir com aldeídos, produzindo o complexo acetaldeído-bissulfito $\left[\mathrm{CH}_{3} \mathrm{CH}(\mathrm{OH}) \mathrm{SO}_{3}^{-}\right]$, cujas propriedades ácidas têm ação corrosiva sobre o material do destilador, sendo que freqüentemente a fração cabeça apresenta alto nível de cobre (Guymon, 1974).

$$
\begin{gathered}
\mathrm{H}_{2} \mathrm{O}+\mathrm{SO}_{2} \rightleftarrows \mathrm{HSO}_{3}^{-}+\mathrm{H}^{+} \\
\mathrm{HSO}_{3}{ }^{-}+\mathrm{CH}_{3} \mathrm{CHO} \rightleftarrows \mathrm{CH}_{3} \mathrm{CH}(\mathrm{OH}) \mathrm{SO}_{3}^{-}
\end{gathered}
$$

As reações que ocorrem durante a primeira destilação em alambique, são mais importantes, sendo influenciadas por vários fatores como: características do vinho, $\mathrm{pH}$, acidez, tamanho do alambique, temperatura gerada sobre a caldeira, tempo de destilação, uso de lees, limpeza do alambique (Léauté, 1990).

Nemoto et al. (1975) ${ }^{12}$ citados por Rose (1977) investigando os efeitos das condições de destilação, especialmente quanto a concentração de ésteres e

${ }^{12}$ NEMOTO, S.; SUGIMOTO, N.; USUI, T. Journal of the Society of Brewing, v.70, p.201, 1975. Apud ROSE, A.H. Alcoholic beverages, London, Academic Press, 1977. cap.9. (Economic Microbiology, 1.). 
ácidos, verificaram que a concentração de ácidos aumenta 3 a 4 vezes, enquanto a concentração de ésteres quase dobra, quando o pH do vinho é reduzido de 4,9 para 2,0 e que a suplementação prévia do vinho com ácido acético e ácido butírico, aumenta a formação de ésteres de etila durante a operação de destilação. Lima (1964), adicionou ao vinho, uma mistura previamente preparada com ácido acético e ácido butírico na proporção de 3:1 até que o vinho acusasse uma acidez correspondente a $12 \mathrm{~g}$ de ácido tartárico por litro e verificou pronunciado aumento na concentração de ésteres, bem como, alteração no aroma das aguardentes.

Lima (1964) constatou que o grau de esterificação durante a destilação e o teor de álcoois superiores no destilado é função da velocidade de destilação independente do tipo de aparelho destilatório.

\subsection{Efeito da destilação de vinhos não centrifugados ou não decantados sobre as características das bebidas}

A presença de células de leveduras nos vinhos, durante a destilação, afeta a concentração de ácidos graxos e ésteres no destilado, pois os ácidos e ésteres de maior peso molecular estão intimamente ligados à célula de levedura, enquanto os de menor peso molecular tendem a passar para o meio de fermentação (Guymon, 1974), assim, ácidos como láurico, palmítico, palmitoléico, esteárico e oléico acumulam nas células e podem aparecer em grandes quantidades durante a destilação de bebidas se o vinho for destilado em presença de leveduras (Suomalainen et al. 1974; Suomalainen \& Nykänen 1966; Suomalainen \& Nurminen, 1976). 
A distribuição dos ésteres de ácidos graxos, produzidos durante a fermentação depende do comprimento da cadeia da parte ácida dos ésteres; assim, o acetato de isoamila e o caproato de etila presentes apenas no meio, caprilato e caprato de etila presentes no meio e nas células, enquanto o laurato de etila é retido nas células. A espécie de levedura utilizada na fermentação influi em alguma extensão na distribuição dos ésteres e ácidos entre as células e o meio, sendo que a S. uvarum parece reter nas células maiores concentrações de caprato e caprilato de etila do que a $S$. cerevisiae (Nykänen et al., 1977).

Guymon (1974) constatou que a concentração de ácidos graxos e ésteres encontrados em brandy destilado, varia em função do tempo entre a fermentação e a destilação, pois no final da fermentação as leveduras decantam, porém pode haver ressuspensão das células, assim o grau de ressuspensão das borras sedimentadas no vinho, influi na concentração de ácidos graxos e ésteres, recuperado no destilado, porém segundo Lindet $(1891)^{13}$ citado por Lima (1964) durante a fermentação complementar, os ạ́lcoois se esterificam ao contato com ácidos, e inclusive os álcoois superiores em menor extensão, dando a aguardente um aroma especial.

\subsection{Influência do cobre na qualidade da aguardente}

A presença de cobre nas bebidas destiladas tem sido um dos problemas intrínsecos à sua produção, pois desde o início da produção de bebidas fermento-

${ }^{13}$ LINDET, M.L. Sur la production des alcools supérieurs-pendant la fermentation alcoolique. Comptes Rendus l'Academie des Science, v.112, n.2, p.102-4, 1891. Apud LIMA, U. de A. Estudos dos principais fatores que afetam os componentes do coeficiente não-álcool das aguardentes de cana. Piracicaba, 1964, 141 p. (Cátedra) - Escola Superior de Agricultura "Luiz de Queiroz", Universidade de São Paulo. 
destiladas, o cobre é o material mais extensivamente utilizado nas construções de alambiques, devido às inúmeras vantagens que apresenta como resistência à corrosão, boa condução de calor, além de reagir com alguns componentes do vinho e atuar como catalizador, em reações altamente favoráveis às características sensoriais da bebida (Léauté, 1990).

Nas aguardentes brasileiras, 'o cobre aparece com frequência, porém nossa legislação permite atualmente um limite máximo de $5 \mathrm{ppm}$, o que pode ser facilmente garantido com higienização correta e constante; porém, embora no Brasil a contaminação pelo cobre não signifique problema legal, a sua presença em nossas caninhas, tem sido, ao lado da falta de padrões de qualidade, os principais obstáculos à sua exportação, pois, a maioria dos países importadores não permite importação de bebidas contaminadas por cobre (Daher \& Freitas, 1980; Faria, 1989). Segundo Serpe \& Freitas (1991), a presença de cobre em alimentos e bebidas é considerado nocivo à saúde pública, pois o excesso desse metal traz para o organismo, lesões nos vasos capilares, no fígado e nos rins, além da chamada doença de Wilson, que é causada pelo acúmulo de cobre nos tecidos.

A presença de cobre nas aguardentes brasileiras é uma preocupação antiga dos pesquisadores brasileiros. Peduti (1943), constatou a presença mais ou menos acentuada em grande número de aguardentes, especialmente naquelas em que as características organolépticas indicavam como sendo de boa origem e salientou a toxidez do cobre à saúde pública, por se apresentar na forma assimilável.

Segundo Lucena (1959) a contaminação pelo cobre ocorre devido os alambiques passarem de safra a safra sem qualquer limpeza mais rigorosa e assim as 
chapas metálicas são atacadas, formando o azinhavre, $\mathrm{CO}_{3} \mathrm{Cu}(\mathrm{OH})_{2} \mathrm{Cu}$ - carbonato básico de cobre, solúvel nos vapores alcoólicos, levemente ácidos, que ao condensarem levam o cobre para o destilado.

Em virtude dos convenientes e inconvenientes do uso de cobre na construção de aparelhos destilatórios, há vários estudos abordando esse tema. Lima (1964) verificou que o material de construção de aparelhos destilatórios não influi na composição do coeficiente não-álcool das aguardentes e sim a técnica de destilação utilizada, enquanto Faria (1989), através de estudo comparativo das aguardentes destiladas na presença e na ausência de cobre, sugeriu a participação dos compostos sulfurados no defeito organoléptico observado nas aguardentes destiladas na ausência de cobre.

Os sais de cobre, durante a destilação mudam o perfil do destilado, pois segundo Ossa \& Serrano (1991), alteram a composição de equilíbrio líquido-vapor, obtendo-se maior separação entre os componentes e através de seu efeito catalítico aumenta a concentração de acetato de etila, com correspondente redução na concentração de acetaldeído, o cobre também reage com ácidos de odor desagradável, como o ácido butírico, capróico, caprílico, cáprico e láurico, formando compostos organo-cúpricos, insolúveis no meio de destilação (Lafon et al., 1964 ${ }^{14}$, citados por Amerine et al., 1972).

${ }^{14}$ LAFON, R.; LAFON, J.; COUILLAUD, P. Le cognac, la distillation. J.B. Baillière et Fils, Paris, 1964. Apud AMERINE, M.A.; BERG, H.W.; CRUESS, W.V. The tecnology of wine making. 3.ed., Westport, The AVI PUBL., 1972. cap. 17. 
Os compostos sulfurados presentes no vinho compreende compostos que contêm enxofre na forma de sulfato $\left(\mathrm{SO}_{4}{ }^{=}\right)$ou pontes dissulfeto (-S-S-), usualmente não voláteis em maior proporção e em menor proporção gás sulfídrico $\left(\mathrm{H}_{2} \mathrm{~S}\right)$ e mercaptanas (Wainwright, 1971; Rigott, $1989^{15}$, citado por Maia, 1994). Durante a destilação o gás sulfídrico é eliminado com facilidade, porém algumas mercaptanas são líquidos voláteis que, quando transferidos para o destilado, mesmo em níveis de partes por bilhão (ppb), conferem-lhe aroma particularmente desagradável. A presença de cobre no domo do alambique é particularmente favorável, uma vez que o íon cúprico (do azinhavre) cataliza a oxidação do gás sulfídrico e das mercaptanas a sulfetos de cobre e dissulfetos, compostos de baixa solubilidade, reduzindo a concentração de compostos sulfurados nos destilados (Novaes et al., 1974; Mitchel1 ${ }^{16}$, citado por Maia, 1994).

$$
\begin{aligned}
& \mathrm{Cu}^{2+}+\mathrm{H}_{2} \mathrm{~S} \rightarrow \mathrm{CuS}+2 \mathrm{H}^{+} \\
& 4 \mathrm{R}-\mathrm{SH}+2 \mathrm{Cu}^{2+} \rightarrow 2 \mathrm{Cu}-\mathrm{SR}+\mathrm{RS}-\mathrm{SR}+4 \mathrm{H}^{+}
\end{aligned}
$$

${ }^{15}$ RIG0TT, J.R. (Ed.). Distilled Beverage Flavour. Weinheim: VCA, 1989, Apud MAIA, A.B. Componentes secundários da aguardente, STAB, v.12, n.6, p.29-34, 1994.

${ }^{16}$ MITCHELL, J. et al. Organic Analysis. New York, Interscience, 1953. v.1, Apud MAIA, A.B. Componentes secundários da aguardente. STAB, v.12, n.6, p.29-34, 1994. 


\section{MATERIAL E MÉTODOS}

\subsection{Fermentação}

\subsubsection{Fermentadores}

No presente trabalho foi utilizado um conjunto de fermentadores projetado pelo Prof. Dr. Jorge Horii do Departamento de Ciência e Tecnologia Agroindustrial da ESALQ/USP, construído pela CONGER (Marques, 1991).

As dornas foram em número de três, construídas em aço inox, com volume útil de 15 litros cada e providas de sistema de resfriamento sob a forma de serpentinas internas em cobre.

Os fermentadores utilizados contêm os seguintes acessórios: banho-maria com controle de temperatura variando de $-40^{\circ} \mathrm{C}$ a $+60^{\circ} \mathrm{C}$, utilizado no bombeamento do líquido até a serpentina e um agitador de palhetas acionado por um motor elétrico com controle de rotação.

\subsubsection{O mosto}

No preparo do mosto foi utilizado caldo de cana-de-açúcar, recémcortada, despalhada manualmente, submetida à moagem, filtrado e diluído com água 
potável até um teor de sólidos solúveis $\left({ }^{\circ}\right.$ Brix $)$ em torno de 14,0 , com suplementação de sulfato de amônio $(0,1 \mathrm{~g} / \mathrm{L})$ e de di-hidrogênio fosfato de potássio $(0,1 \mathrm{~g} / \mathrm{L})$.

Quando necessário, em função do controle operacional, foram empregados antiespumante (Silcolapse 5000) e antibiótico (Kamoran HJ 3,0 mg/L), durante as fermentações realizadas.

\subsubsection{O inóculo}

O fermento utilizado foi Saccharomyces cerevisiae na forma de fermento biológico prensado comercial (Fleischmann).

Foram pesados em balança eletrônica, 150 gramas de fermento prensado e, a seguir, suspensos em $1000 \mathrm{~mL}$ de mosto a $30-32^{\circ} \mathrm{C}$. A suspensão resultante foi utilizada como inóculo, para um volume final de $15.000 \mathrm{~mL}$, o que representa uma concentração de inóculo da ordem de $3 \mathrm{gL}^{-1}$ em peso seco.

\subsubsection{Condução da fermentação}

As fermentações foram conduzidas à temperatura ajustada entre $30-32^{\circ} \mathrm{C}$, sob agitação (380 rpm). Durante as fermentações, acompanhou-se a atenuação do ${ }^{\circ}$ Brix, por meio de um areômetro de Brix, provido de termômetro, aferido a $20^{\circ} \mathrm{C}$.

As fermentações foram realizadas sem reciclo de células, sendo o fermento removido do vinho através do processo de decantação ou através de centrifugação. 


\subsection{Destilação}

\subsubsection{Conjunto de destilação}

No presente trabalho foi utilizado um alambique simples, de aço inoxidável, vertical, tipo Besnard-Estève modificado, de carga intermitente, com bandejas de cobre electrolítico ( $8 \%$ de área perfurada), sem pré-aquecedor de vinho, sem retrogradação, com condensador-refrigerante, munido de serpentina de cobre, fabricação MORLET. Sistema de aquecimento a eletricidade através de duas resistências de 3 kilowatts, 220 volts, no interior da caldeira, controlado por um reostato, construído pela MARCONI. O equipamento está esquematizado na Figura 1. 
1 - Coldeiro

2- Tronco de destilação

3- Termômetro

4-Condensador-resfriadeira tipo serpentina

5- Saída do destilado

6- Entrada do vinho

7-Descarga de vinhaça

8-Reostato

9-Respiro
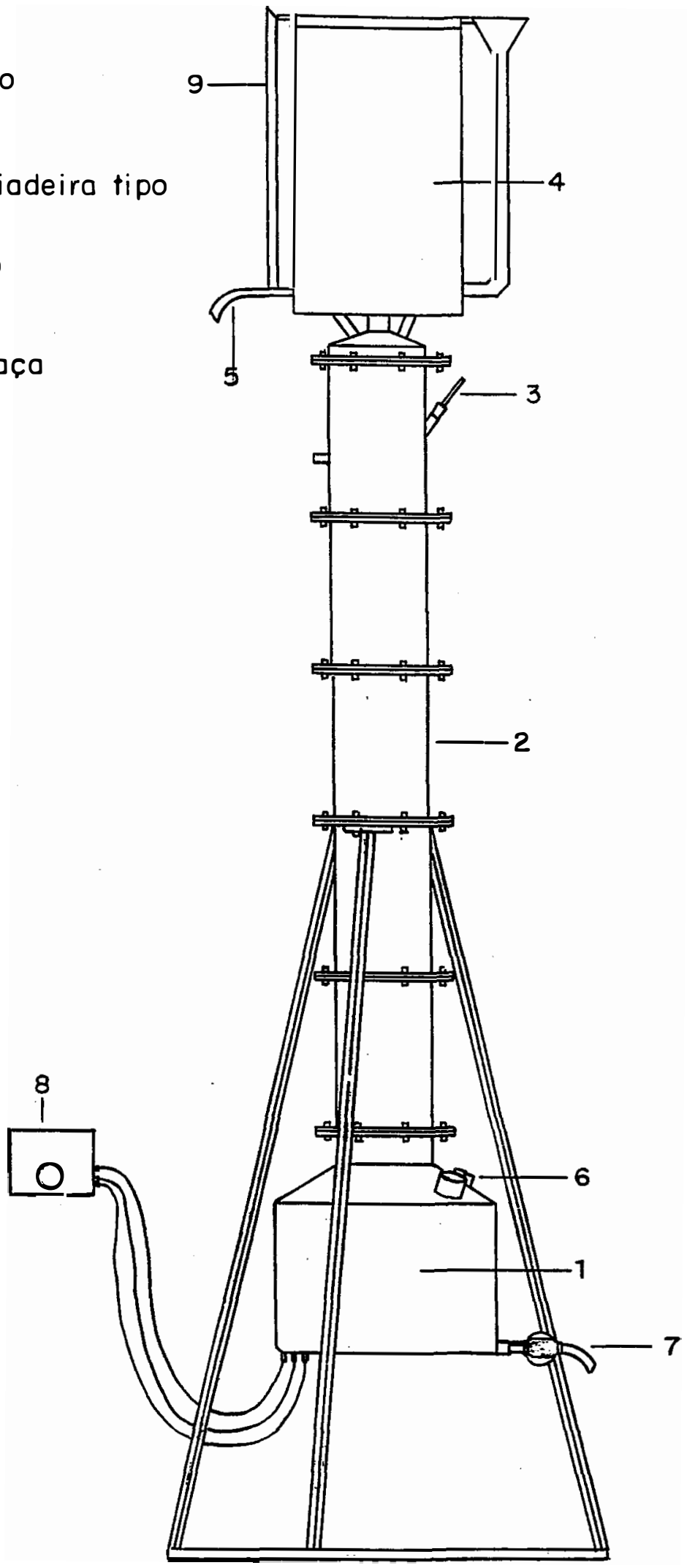

Figura 1 - Esquema do conjunto de destilação Besnard-Estève 


\subsubsection{Condução da destilação}

O método de trabalho adotado para se obter resultados comparáveis, foi a destilação de vinho resultante da fermentação do mosto, decantado ou centrifugado, mantendo-se constantes as seguintes condições: tipo de destilador, velocidade e fonte de aquecimento. A temperatura de aquecimento da fonte foi invariável no experimento; foi estabelecido, após preliminares, realizarem-se as destilações de modo lento. O volume de vinho adicionado à caixa de recepção da coluna de destilação foi de 12 litros.

\subsubsection{Fracionamento do destilado}

Nesta série de ensaios, para possibilitar a tomada de amostra e uniformizar o trabalho de fracionamento do destilado, admitiu-se um rendimente de $13,3 \%$ de aguardente em relação ao volume do vinho destilado, que foi constante e igual a 12 litros. Considerou-se ainda $6,25 \%$ do volume do destilado como produtos de cabeça, ou seja, $0,1 \mathrm{~L}$, os seguintes $56,25 \%$ do destilado como produtos de coração, num total de $0,9 \mathrm{~L}$ e finalmente, $37,5 \%$ do destilado como produtos de cauda, correspondente a 0,6 L, de acordo com ensaios e análises preliminares.

No ensaio, foram realizadas três destilações subsequentes, na primeira destilação foram reunidos os produtos de cabeça, coração e cauda numa só amostra, na segunda destilação reunidos os produtos de coração e cauda e, finalmente na terceira destilação, reunidos os produtos de cabeça e coração, sendo compostas as soluções geradoras das aguardentes 4,5 e 6 , respectivamente. 
As 3 amostras de destilado foram ajustadas quanto ao teor alcoólico com água potável a aproximadamente $40 \%$ em volume a $20^{\circ} \mathrm{C}$ e submetidas a análises objetiva e subjetiva.

\subsubsection{Natureza e composição dos vinhos}

\subsubsection{1. $\mathrm{pH}$ inicial do vinho}

$\mathrm{O}$ procedimento adotado para o estudo da influência do $\mathrm{pH}$ inicial do vinho foi o seu aumento através da adição de suspensão aquosa de hidróxido de cálcio ao vinho decantado, monitorado através de leituras de $\mathrm{pH}$, efetuadas em potenciômetro Digimed, modelo DMPH-2. Foram assim obtidos vinhos tratados a $\mathrm{pH} 6,0 ; 4,99$ e 4,06, que em seguida foram destilados, sendo os destilados geradores das aguardentes 10,11 e 12 , respectivamente.

\subsection{Células de leveduras no vinho}

A influência da presença de células de leveduras no destilado foi estudada através da utilização de 2 sistemas de remoção do fermento: decantação e centrifugação em centrífuga marca International Portable Refrigerated Centrifuge, modelo PR-2, por 15 minutos a $2000 \mathrm{rpm}$, correspondendo a $1007 \mathrm{G}$, em temperatura mantida a $5^{\circ} \mathrm{C}$. Os vinhos decantado, centrifugado e centrifugadotratado a $\mathrm{pH} \mathrm{4,0} \mathrm{foram} \mathrm{destilados,} \mathrm{sendo} \mathrm{os} \mathrm{destilados} \mathrm{geradores} \mathrm{das} \mathrm{aguardentes} \mathrm{4,}$ 13 e 14 , respectivamente. 


\subsection{Remoção de compostos voláteis da matéria-prima no vinho}

Para o preparo do mosto, o procedimento técnico foi o seguinte: $\mathrm{O}$ caldo de cana foi filtrado em algodão e diluído, com água potável e 1,0 L de álcool neutro (96,02\% v) previamente tratado com carvão ativo, até a concentração de 14,8-14,9 Brix e teor alcóolico em volume de $8 \%$. O caldo assim diluído foi destilado nas mesmas condições de destilação dos vinhos. $\mathrm{O}$ término da destilação foi determinado quando a fração do destilado apresentou densidade 0,9982 ; essa operação foi repetida. Em seguida, ajustou-se o ${ }^{\circ}$ Brix do caldo com água potável e adotou-se o mesmo procedimento utilizado na obtenção dos demais vinhos. Os vinhos decantados e centrifugados foram destilados, sendo os destilados geradores das aguardentes 15 e 16 , respectivamente.

\subsection{Teor alcoólico}

Nesse estudo, obteve-se um vinho cuja concentração de álcool em volume foi de $10,24 \%$ a $20^{\circ} \mathrm{C}$, a partir da fermentação de um mosto com teor de sólidos solúveis em torno de 19,0, adotando-se o mesmo procedimento utilizado na obtenção dos demais vinhos. Em seguida, o vinho foi destilado, sendo este o gerador da aguardente 18.

Os vinhos obtidos em 3.2.2.2.1; 3.2.2.2.2.; 3.2.2.2.3 e 3.2.2.2.4, foram destilados, admitindo-se um rendimento de $13,3 \%$ de aguardente em relação ao volume de vinho destilado. Os destilados tiveram o grau alcoólico ajustado, com água potável a, aproximadamente, $40 \%$ em volume, a $20^{\circ} \mathrm{C}$ e foram submetidos a análises objetiva e subjetiva. 
A aguardente 17, sem marca, (de produção clandestina), adquirida à granel, produzida e comercializada no município de Votuporanga,SP, de concentração alcoólica de $37,07 \%$ em volume a $20^{\circ} \mathrm{C}$, fora de especificação, portanto, foi produzida por processo artesanal, ou seja, fermentação natural, destilada em alambique simples de cobre e armazenada em recipientes de madeira. Foram realizadas análises físico-química e sensorial na aguardente, já que ela se aproximaria de uma aguardente recém-destilada, de alambique simples.

\subsubsection{Redestilação}

Nesse estudo foram realizados 2 experimentos sendo que, para cada um foram realizadas 2 destilações subsequentes. As destilações foram conduzidas sob as seguintes condições experimentais:

a) na primeira destilação dos vinhos decantados conduziu-se a destilação até o destilado apresentar um teor alcoólico de 25-27\% em volume, correspondendo a um volume médio de destilado de 3,25 L. Essa operação foi repetida três vezes, restaurando-se o volume inicial $(12 \mathrm{~L})$, por combinação dos 4 destilados.

Os destilados alcoólicos das 4 destilações combinados resultaram numa mistura hidroalcoólica a $25,9 \%$ em volume a $20^{\circ} \mathrm{C}$, onde foi procedida a segunda destilação, cujo destilado foi fracionado em frações de $0,25 \mathrm{~L}$. Com as frações obtidas, após homogeneização, foram compostas as soluções geradoras das aguardentes 8 e 9. A partir da remoção sucessiva de $0,10 \mathrm{~L}$ das frações que destilam de 84,79 até $61,05 \%$ em volume a $20^{\circ} \mathrm{C}$ [valores acumulados, conforme Tabela $35(1)$ ], obteve-se um produto com teor alcoólico de $60,73 \%$ em volume a $20^{\circ} \mathrm{C}$, a partir do qual obteve-se a aguardente 8 . 
Foi realizada uma outra composição de frações, separando $0,05 \mathrm{~L}$ das frações que destilam de 75,83 a $61,05 \%$ de etanol em volume a $20^{\circ} \mathrm{C}$ [valores acumulados, conforme Tabela 35(1)], obtendo-se um produto com teor alcóolico de $46,58 \%$ em volume a $20^{\circ} \mathrm{C}$, a partir do qual originou a aguardente 9 .

b) na primeira destilação do vinho decantado conduziu-se a destilação até o destilado apresentar um teor alcoólico de $47,65 \%$ em volume a $20^{\circ} \mathrm{C}$. O destilado foi diluído com água potável resultando uma mistura hidroalcoólica a 6,25\% em volume, sendo que essa mistura foi redestilada, sendo o novo destilado recolhido em frações de $100 \mathrm{~mL}$ ou múltiplo, e após homogeneização foi composta a solução geradora da aguardente 7. A partir da remoção sucessiva de $50,0 \%$ do volume das frações que destilam de 78,55 a $61,84 \%$ em volume de etanol a $20^{\circ} \mathrm{C}$ [valores acumulados, conforme Tabela 36(1)], obteve-se um produto com teor alcoólico de $59,62 \%$ em volume a $20^{\circ} \mathrm{C}$.

As frações obtidas nos 2 experimentos foram analisadas quanto à acidez, compostos voláteis e teor alcoólico.

Os 3 destilados obtidos nos 2 experimentos foram diluídos com água potável até cerca de $40,0 \%$ de álcool em volume a $20^{\circ} \mathrm{C}$ e considerados como aguardente de cana, sendo submetidos a análises objetiva e subjetiva.

\subsubsection{Teor alcoólico, acidez e teor de cobre do destilado}

A destilação do vinho decantado foi conduzida até que o destilado recolhido acumulado apresentasse com um teor alcoólico de 46,51\% em volume a $20^{\circ} \mathrm{C}$, sendo que no transcorrer da destilação foram removidas alíquotas sucessivas 
do destilado e analisadas quanto à acidez total, teor de cobre, compostos voláteis e teor alcoólico.

\subsection{Métodos analíticos}

\subsubsection{Vinhos}

As concentrações de etanol e acidez volátil foram determinadas após o término das fermentações sobre alíquotas destiladas do vinho.
a) Acidez volátil
Por titulometria de neutralização conforme Brasil (1986).
b) Teor alcoólico (\%v)
Determinado com densímetro Anton-Paar, modelo DMA 45.
c) Determinação de $\mathrm{pH}$
Por potenciometria, potenciômetro Digimed, modelo DMPH-2.

\subsubsection{Aguardente}

\subsubsection{Análises objetivas}

a) Teor alcoólico (\% v)

Determinado com densímetro Anton-Paar, modelo DMA 45.

b) Acidez total

Determinação segundo as Normas Analíticas do Instituto Adolfo Lutz (1985). 
c) Compostos voláteis

Determinação através de análises cromatográficas, efetuadas no cromatógrafo de fase gasosa marca CG modelo 37D, equipado com detector de ionização de chama e coluna de aço inoxidável de $3 \mathrm{~m} \times 1 / 8$ ", contendo Hallcomid M-18 e Carbowax 1500. As condições de operação para determinação de álcoois superiores foram as seguintes: temperatura da coluna $98^{\circ} \mathrm{C}$, temperatura do injetor $140^{\circ} \mathrm{C}$, temperatura do detector $250^{\circ} \mathrm{C}$; gás de arraste nitrogênio/fluxo $40 \mathrm{~mL} / \mathrm{min}$ e os volumes injetados de 2 microlitros. As análises cromatográficas foram realizadas pela Seção de Cromatografia do Departamento de Ciência e Tecnologia Agroindustrial / Setor de Álcool e Açúcar.

d) Análise de Cobre

As determinações de cobre foram feitas em espectrômetro de absorção atômica marca Intralab-Gemini modelo AA12/1475, equipado com lâmpada de cátodo oco. As medidas foram feitas a $324,8 \mathrm{~nm}$, com abertura de fenda de 0,7 nm e intensidade de corrente $4 \mathrm{~mA}$.

As alíquotas de destilado tiveram o teor alcoólico corrigidos a aproximadamente $40 \%$ em volume, através da adição de álcool etílico e de água desmineralizada. A solução de trabalho foi preparada a partir do padrão de sulfato de cobre pentahidrato (Merck), álcool etílico e água desmineralizada, obtendo-se uma solução com concentração de cobre de $1000 \mathrm{mg} \mathrm{L}^{-1}$ e teor alcoólico de $40 \%$ em volume. A partir desta foram preparadas por diluição com solução hidroalcoólica a $40 \%$ em volume de etanol, todas as soluções padrão de cobre exigidas no presente trabalho.

\subsubsection{Análise sensorial}

As amostras de aguardentes obtidas sob diferentes condições de destilação foram avaliadas subjetivamente quanto ao flavor. 
As avaliações das amostras foram realizadas por uma equipe de provadores, previamente selecionada e treinada para esse tipo de avaliação.

Com o objetivo de selecionar indivíduos que tenham maior sensibilidade para detectar pequenas diferenças no flavor da aguardente, foram submetidos a uma série de testes triangulares, utilizando amostras de aguardentes disponíveis no mercado. A pré-seleção dos provadores foi realizada tomando por base seu interesse, facilidade para se expressar e disponibilidade de tempo. Foi formado um grupo inicial de 23 provadores de ambos os sexos. Após aplicação de testes triangulares formou-se um grupo de 8 provadores que melhor discriminavam as aguardentes.

$\mathrm{Na}$ análise sensorial foi utilizada como amostra-referência a aguardente 04, recém-destilada, cuja graduação alcoólica foi ajustada com água potável e engarrafada, sendo considerada como referencial para efeito de avaliação na análise das aguardentes obtidas.

No teste triangular, três amostras foram apresentadas ao provador, das quais duas eram iguais e uma diferente. O provador foi solicitado à selecionar a amostra diferente (Modelo de ficha utilizada na Figura 2).

\section{ANÁLISE SENSORIAL}

PRODUTO DATA

NOME:

Duas amostras são iguais e uma é diferente. Faça um círculo na amostra diferente.

$n^{0}$ da amostra $\underline{125}$ $\underline{437}$ $\underline{728}$

Figura 2 - Modelo de Ficha do Teste Triangular. 
$\mathrm{Na}$ avaliação das aguardentes, segundo Fonseca et al. (1985), os julgadores avaliaram as amostras atribuindo-lhes notas de 1 (um) a 10 (dez) para o atributo flavor e assinalaram em uma ficha fornecida a cada um. O modelo de ficha utilizada nesta avaliação está apresentada na Figura 3. Para a amostra-referência foi previamente atribuída a nota 6 (seis), para que os julgadores avaliassem relativamente as amostras, conforme a escala abaixo:

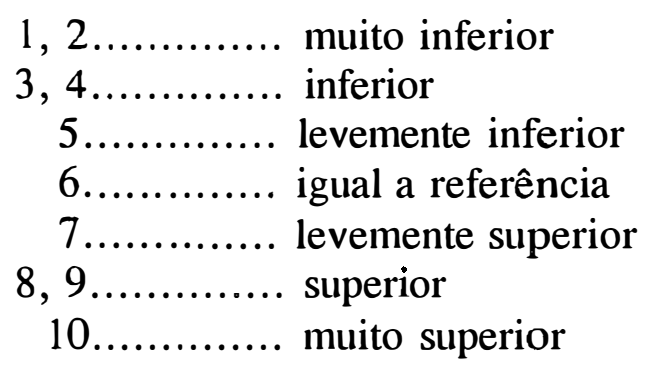

Cada amostra de aguardente foi servida a cada julgador, duas vezes, porém em sessões diferentes, para assegurar uma melhor avaliação do produto. As notas atribuídas nas duas sessões pela equipe de julgadores, para cada aguardente, foram somadas e, em seguida, obteve-se um valor médio.

\section{A N Á L I S E S E N S O R I A L}

NOME:

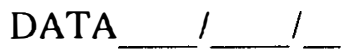
PRODUTO:

\begin{tabular}{|c|c|c|c|c|c|c|c|}
\hline AMOSTRAS & $\begin{array}{c}\text { MUITO } \\
\text { INFERIOR } \\
1 \text { - } 2\end{array}$ & $\begin{array}{c}\text { INFERIOR } \\
3-4\end{array}$ & $\begin{array}{l}\text { LEVEMENTE } \\
\text { INFERIOR } \\
5\end{array}$ & $\begin{array}{c}\text { IGUAL } \\
6\end{array}$ & $\begin{array}{l}\text { LEVEMENTE } \\
\text { SUPERIOR } \\
7\end{array}$ & $\begin{array}{c}\text { SUPERIOR } \\
8 \text {-9 }\end{array}$ & $\begin{array}{c}\text { MUITO } \\
\text { SUPERIOR } \\
10\end{array}$ \\
\hline REFERÊNCIA & & & & $\mathrm{x}$ & & & \\
\hline & & & & & & & \\
\hline & & & & & & & \\
\hline & & & & & & & \\
\hline & & & & & & & \\
\hline
\end{tabular}

Figura 3 - Modelo de ficha utilizada na avaliação sensorial das amostras quanto ao flavor. 


\subsubsection{Análise Estatística}

A análise estatística dos resultados obtidos na análise sensorial foi feita através do teste t. Foram comparadas as médias das notas atribuídas à cada aguardente com a média 6,0 atribuída à aguardente-referência. Na análise sensorial das aguardentes foram realizadas 16 repetições, o que resultou em 15 graus de liberdade para a consulta as tabelas de t. Segundo Gomes (1990), para os níveis de probabilidade a $1 \%, 5 \%$ e $10 \%$, os valores tabelados de t, são: 2,$95 ; 2,13$ e 1,75. Os resultados obtidos nas análises objetiva e subjetiva das aguardentes foram analisados através da análise de fatores pelo Método dos Componentes Principais (Anderson, 1984). 


\section{RESULTADOS E DISCUSSÃO}

Os resultados obtidos do estudo da influência do fracionamento do destilado, da natureza e composição dos vinhos e do efeito da redestilação sobre a qualidade da aguardente, bem como o efeito da composição química do destilado sobre o teor de cobre nas aguardentes, estão contidas em Tabelas e Figuras no texto, que serão apresentadas individualmente para melhor compreensão de cada ensaio.

Os resultados das análises físico-químicas e sensorial das aguardentes, obtidas na série de experimentos, foram avaliados inicialmente a partir das informações que cada tipo de análise proporciona e, em seguida, foram estabelecidas relações entre as análises sensorial e físico-química.

\subsection{Influência do fracionamento do destilado}

Nessa série de experimentos, preliminarmente foi verificada a influência do fracionamento do destilado, pois os resultados obtidos além das informações inerentes, orientou-nos a estabelecer o grau de fracionamento dos demais destilados, obtidos no estudo das demais variáveis, viabilizando a obtenção de resultados comparáveis.

Antes de serem apresentados os resultados dos experimentos, temos que esclarecer alguns pontos da metodologia aplicada, através de resultados de ensaios preliminares. 
Inicialmente, baseado nas variações acentuadas de odor do destilado na saída do condensador, foi estabelecido um rendimento de $15 \%$ de aguardente em relação ao volume de vinho destilado (12 L). Consideramos $0,3 \mathrm{~L}$ iniciais do destilado como produtos de cabeça, os seguintes 1,2 L como produtos de coração e finalmente, 0,3 L como produtos de cauda. Realizamos 3 destilações subsequentes, sendo que na primeira destilação reunimos os produtos de cabeça e coração, na segunda destilação reunimos os produtos de coração e finalmente na terceira destilação, reunimos os produtos de cabeça, cauda e coração numa só amostra. As amostras foram diluídas com água potável a aproximadamente $40 \% \mathrm{v}$ em teor alcoólico, correspondendo às aguardentes 1, 2 e 3, respectivamente. As aguardentes foram submetidas a análises objetiva e subjetiva, sendo que na análise sensorial a aguardente "3" foi considerada aguardente "referência". Os resultados obtidos no referido ensaio preliminar estão mostrados nas Tabelas 4, 5, 6 e 7 .

A partir dos resultados obtidos na análise sensorial preliminar e informações da literatura, Léauté (1990), procedeu-se o fracionamento conforme descrito no ítem anterior e foram obtidas as aguardentes 4,5 e 6, (sendo a aguardente 4, denominada amostra "referência" para efeito de avaliação sensorial no presente estudo). Os resultados analíticos e de condução do ensaio estão mostrados nas Tabelas $8,9,10$ e 11 . 
Tabela 4 - Valores de Brix dos caldos de cana e dos mostos, teor alcoólico e acidez volátil dos vinhos

\begin{tabular}{ccccc}
\hline \hline $\begin{array}{c}\text { Aguardente } \\
*\end{array}$ & $\begin{array}{c}{ }^{\circ} \text { Brix } \\
\text { Caldo de Cana }\end{array}$ & $\begin{array}{c}{ }^{\circ} \text { Brix } \\
\text { Mosto }\end{array}$ & $\begin{array}{c}\text { Álcool Vinho } \\
(\% \mathrm{v})\end{array}$ & $\begin{array}{c}\text { Acidez Volátil } \\
\text { Vinho } \\
\text { mgHAc/100 mL }\end{array}$ \\
\hline 1 & 19,0 & 14,4 & 7,56 & 14,40 \\
2 & 19,7 & 14,2 & 7,41 & 14,40 \\
3 & 21,6 & 14,3 & 8,92 & 17,81 \\
\hline \hline
\end{tabular}

*Obs: Ver observação sob a Tabela 7.

Tabela 5 - Valores do teor alcoólico e volume dos destilados

\begin{tabular}{ccc}
\hline Aguardente & $\begin{array}{c}\text { Volume do destilado } \\
(\mathrm{mL})\end{array}$ & $\begin{array}{c}\text { Álcool destilado } \\
(\% \mathrm{v})\end{array}$ \\
\hline 1 & 1500 & 49,01 \\
2 & 1200 & 45,59 \\
3 & 1800 & 46,25 \\
\hline
\end{tabular}

Tabela 6 - Acidez total, grau alcoólico e análise sensorial (média) das aguardentes

\begin{tabular}{cccc}
\hline \hline Aguardente & $\begin{array}{c}\text { Acidez Aguardente } \\
(\mathrm{mg} \mathrm{HAc} / 100 \mathrm{~mL})\end{array}$ & $\begin{array}{c}\text { Álcool Aguardente } \\
(\% \mathrm{v})\end{array}$ & $\begin{array}{c}\text { Análise Sensorial } \\
(\text { média })\end{array}$ \\
\hline 1 & 2,66 & 39,97 & 7,12 \\
2 & 2,72 & 40,03 & 4,81 \\
3 & 3,44 & 40,03 & 6,0 \\
\hline \hline
\end{tabular}




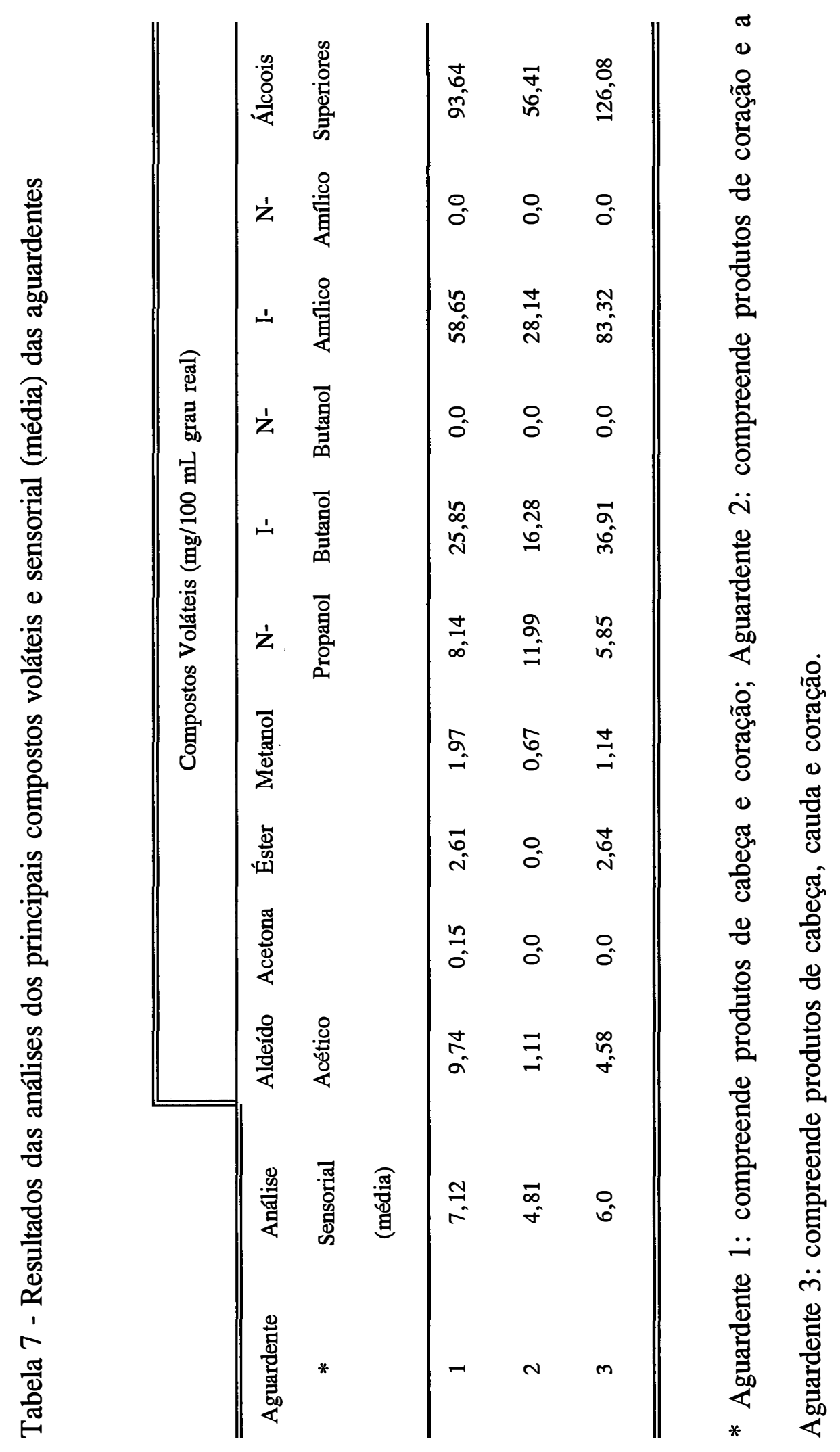


Observa-se que as aguardentes 1 e 2, oriundas de vinhos que apresentaram acidez volátil iguais $(14,40 \mathrm{mg} \mathrm{H} \mathrm{Ac/100} \mathrm{mL),} \mathrm{submetidos} \mathrm{a} \mathrm{diferentes}$ graus de fracionamento apresentaram pequena diferença quanto à acidez total 2,66 e 2,72 $\mathrm{mg} \mathrm{H} \mathrm{Ac/100} \mathrm{mL,} \mathrm{respectivamente,} \mathrm{enquanto} \mathrm{a} \mathrm{aguardente} \mathrm{3,} \mathrm{proveniente} \mathrm{de}$

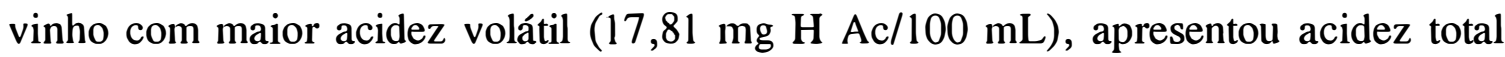
maior $(3,44 \mathrm{mg} \mathrm{H} \mathrm{Ac/100} \mathrm{mL).} \mathrm{Portanto,} \mathrm{a} \mathrm{acidez} \mathrm{total} \mathrm{das} \mathrm{aguardentes} \mathrm{manteve}$ certa proporcionalidade com a acidez do vinho. Segundo Zee et al. (1984) a qualidade dos brandies é também afetada pela acidez volátil dos vinhos.

Através da média de pontos atribuída pela equipe de provadores ao atributo flavor das aguardentes 1 e 2 em relação à aguardente 3 (amostra referência), verificou-se que a aguardente 1 é uma aguardente de flavor mais agradável, enquanto a aguardente 2, essa livre de produtos de cabeça e cuja acidez total é ligeiramente superior à aguardente 1 , foi considerada de qualidade inferior, conforme dados da Tabela 6.

As aguardentes 1 e 3 apresentaram teores de aldeído acético e éster (acetato de etila), superiores ao encontrado na aguardente 2, pois ambos são produtos encontrados na fração cabeça, devido seus baixos pontos de ebulição $\left(21\right.$ e $74,3^{\circ} \mathrm{C}$, respectivamente).

A aguardente 1, considerada de melhor qualidade pela equipe de provadores, apresentou um teor de álcoois superiores de 93,64 mg/100 mL grau real, que está em concordância com Guymon $(1970)^{17}$, citado por Zee et al. (1984), que sugerem um limite de óleo fúsel entre 60 a $120 \mathrm{mg} / 100 \mathrm{~mL}$ à $50 \% \mathrm{v} / \mathrm{v}$ álcool, para que esses não confiram odor e sabor desagradável em brandy.

\footnotetext{
${ }^{17}$ GUYMON, J.F. American Journal of Enology and Viticulture, v.21, p.61, 1970. Apud ZEE, J.A.; SIMARD, R.E.; CARBILLET, L.; LEBEL, C.; LIBER, C. Comparative composition of fusel oils in brandies made from six grapes varieties and their relationship with sensory analysis. Lebensmittel Wissenschaft und Technologie, v.15, p.54-9, 1984.
} 
Tabela 8 - Valores de Brix dos caldos de cana e dos mostos, teor alcoólico e acidez volátil dos vinhos

\begin{tabular}{ccccc}
\hline $\begin{array}{c}\text { Aguardente } \\
*\end{array}$ & $\begin{array}{c}{ }^{\circ} \text { Brix } \\
\text { Caldo de Cana }\end{array}$ & $\begin{array}{c}{ }^{\circ} \text { Brix } \\
\text { Mosto }\end{array}$ & $\begin{array}{c}\text { Álcool vinho } \\
(\% \mathrm{v})\end{array}$ & $\begin{array}{c}\text { Acidez Volátil Vinho } \\
\text { mgHAc/100 mL }\end{array}$ \\
\hline 4 & 23,0 & 14,4 & 8,20 & 11,4 \\
5 & 23,0 & 14,4 & 8,20 & 11,7 \\
6 & 23,1 & 14,3 & 8,92 & 18,6 \\
\hline \hline
\end{tabular}

*OBS: Ver a observação sob a Tabela 11 .

Tabela 9 - Valores do teor alcoólico e volume dos destilados

\begin{tabular}{ccc}
\hline \hline Aguardente & Volume do Destilado & $\begin{array}{c}\text { Álcool Destilado } \\
(\% \mathrm{v})\end{array}$ \\
\hline 4 & 1600 & 52,48 \\
5 & 1500 & 50,44 \\
6 & 1000 & 63,10 \\
\hline \hline
\end{tabular}

Tabela 10 - Acidez total, grau alcoólico e análise sensorial (média) das aguardentes

\begin{tabular}{cccc}
\hline \hline Aguardente & $\begin{array}{c}\text { Acidez Aguardente } \\
(\mathrm{mg} \mathrm{HAc} / 100 \mathrm{~mL})\end{array}$ & $\begin{array}{c}\text { Álcool Aguardente } \\
(\% \mathrm{v})\end{array}$ & $\begin{array}{c}\text { Análise Sensorial } \\
(\mathrm{média})\end{array}$ \\
\hline 4 & 2,34 & 39,34 & 6,0 \\
5 & 2,30 & 42,04 & 5,0 \\
6 & 2,40 & 40,22 & 6,31 \\
\hline \hline
\end{tabular}




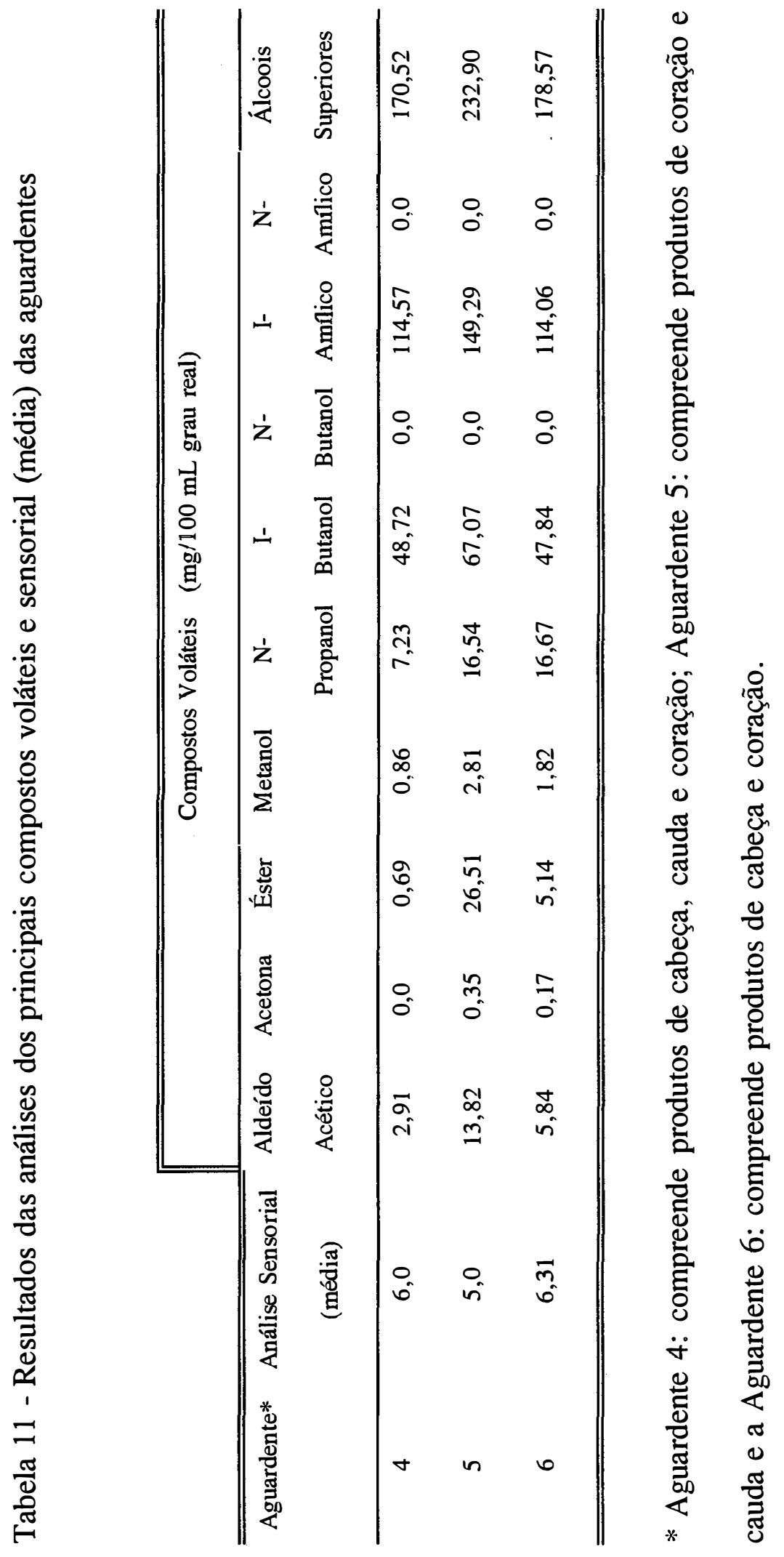


Segundo Amerine et al. (1972), quanto maior o grau de remoção da fração cabeça, melhor a qualidade do brandy, oriundo de vinhos de baixa qualidade, enquanto reduz a qualidade daqueles feitos a partir de vinhos de boa qualidade, pois quando o vinho é bom, o odor das caudas é menos desejável do que aquele das cabeças. Correlacionando os resultados da análise sensorial com o tipo de fracionamento dos destilados originários das aguardentes 4, 5 e 6, observou-se que a remoção da fração cabeça foi um fator negativo quanto ao flavor da aguardente.

A aguardente 5 considerada de baixa qualidade em relação à aguardentereferência, apresentou maior teor de álcoois superiores $(232,90 \mathrm{mg} / 100 \mathrm{~mL}$ grau real) e de álcool isoamílico $(149,29 \mathrm{mg} / 100 \mathrm{~mL}$ grau real) em relação a aguardente 4, cujos teores encontrados foram 170,52 e $114,57 \mathrm{mg} / 100 \mathrm{~mL}$ grau real, respectivamente. Segundo Reazin (1969), o álcool isoamílico, entre os álcoois superiores, é o que apresenta maior mudança de odor a pequenas variações de concentração.

As aguardentes 4 e 5 provenientes de vinhos com acidez volátil semelhante, apresentaram valores de acidez total próximos (2,34 e 2,30 mg HAc/100 $\mathrm{mL}$, respectivamente) enquanto a aguardente 6 , oriunda de vinho com maior acidez volátil e livre dos produtos de cauda apresentou acidez total de 2,40 mg HAc/100 $\mathrm{mL}$.

\subsection{Influência da natureza e composição dos vinhos}

\subsection{1. pH inicial do vinho}

Os resultados analíticos e de condução do ensaio estão mostrados nas Tabelas $12,13,14$ e 15 . 
Tabela 12 - Valores de Brix dos caldos de cana e dos mostos, teor alcoólico, acidez volátil e $\mathrm{pH}$ dos vinhos tratados com $\mathrm{Ca}(\mathrm{OH})_{2}$.

\begin{tabular}{ccccccc}
\hline $\begin{array}{c}\text { Aguardente } \\
*\end{array}$ & $\begin{array}{c}{ }^{\circ} \text { Brix } \\
\text { Caldo de Cana }\end{array}$ & $\begin{array}{c}{ }^{\circ} \text { Brix } \\
\text { Mosto }\end{array}$ & $\begin{array}{c}\text { Álcool vinho } \\
(\% \mathrm{v})\end{array}$ & $\begin{array}{c}\text { Acidez Volátil } \\
\text { Vinho } \\
\text { mgHAc/100 mL }\end{array}$ & \multicolumn{2}{c}{$\mathrm{pH}$ vinho } \\
inicial & final \\
\hline 10 & 21,6 & 14,3 & 8,78 & 17,81 & 3,49 & 6,0 \\
11 & 21,7 & 14,3 & 8,92 & 13,36 & 3,48 & 4,99 \\
12 & 19,4 & 14,5 & 8,34 & 16,08 & 3,39 & 4,06 \\
4 & 23,0 & 14,4 & 8,20 & 11,4 & - & - \\
\hline \hline
\end{tabular}

*Obs: Ver observação sob a Tabela 15.

Tabela 13 - Valores do teor alcoólico e volume dos destilados

\begin{tabular}{ccc}
\hline \hline Aguardente & $\begin{array}{c}\text { Volume do Destilado } \\
(\mathrm{mL})\end{array}$ & $\begin{array}{c}\text { Álcool Destilado } \\
(\% \mathrm{v})\end{array}$ \\
\hline 10 & 1600 & 50,54 \\
11 & 1555 & 50,44 \\
12 & 1600 & 49,11 \\
4 & 1600 & 52,48 \\
\hline \hline
\end{tabular}

Tabela 14 - Acidez total, grau alcoólico e análise sensorial (média) das aguardentes

\begin{tabular}{cccc}
\hline \hline Aguardente & $\begin{array}{c}\text { Acidez Aguardente } \\
(\mathrm{mg} \mathrm{HAc} / 100 \mathrm{~mL})\end{array}$ & $\begin{array}{c}\text { Álcool Aguardente } \\
(\% \mathrm{v})\end{array}$ & $\begin{array}{c}\text { Análise Sensorial } \\
(\mathrm{média})\end{array}$ \\
\hline 10 & 5,45 & 40,00 & - \\
11 & 1,62 & 40,10 & - \\
12 & 2,92 & 39,91 & 5,56 \\
4 & 2,34 & 39,34 & 6,0 \\
\hline \hline
\end{tabular}


A correção da acidez em vinhos e aguardentes, é uma prática comum de alguns produtores de aguardente, através do aquecimento excessivo das serpentinas de condensação por meio do controle da água de resfriamento para promover maior degasagem do destilado e, consequentemente, corrigir a acidez excessiva das aguardentes, procedimento este não recomendável (Stupiello, 1979) ou ainda adição de "cal viva" ( $\mathrm{CaO})$ nas aguardentes de qualidade inferior.

Almeida et al. (1947) recomendam a neutralização parcial do vinho a ser destilado para se obter aguardente de qualidade. Capla et al. (1983) relatam que a utilização de metais alcalinos terrosos, sob a forma de óxido, hidróxido ou carbonato, na obtenção de destilados alcoólicos, resulta em produto com menor concentração de dióxido de enxofre, aldeídos e metais pesados. Amerine et al. (1972) afirmam que a destilação de vinhos contendo dióxido de enxofre, resulta brandies com alta concentração de ácidos fixos e de aldeídos e apresentam um característico e desagradável odor.

A neutralização parcial dos vinhos com adição da suspensão de $\mathrm{Ca}(\mathrm{OH})_{2}$, "água de cal" em concentrações ( $\mathrm{CaO} 90 \%)$ 0,75; 1,56 e 3,50 $\mathrm{g} \mathrm{L}^{-1}$, obtiveram vinhos à pH 4,06; 4,99 e 6,0 respectivamente, sendo que a relação entre os gramas de reagente corretor e o $\mathrm{pH}$ obtido variou em função da capacidade tamponante dos vinhos.

As aguardentes 11 e 12 obtidas a partir dos vinhos tratados com $\mathrm{Ca}(\mathrm{OH})_{2}$, apresentaram decréscimo na acidez total em função da extensão do grau de neutralização. As aguardentes 10 e 11 não foram submetidas à análise sensorial por apresentarem um odor muito desagradável, embora a aguardente 11 apresentasse acidez total inferior à amostra-referência. A aguardente 12 foi submetida à avaliação sensorial e obteve uma média de pontos, quanto ao atributo flavor, inferior ao da amostra-referência. 


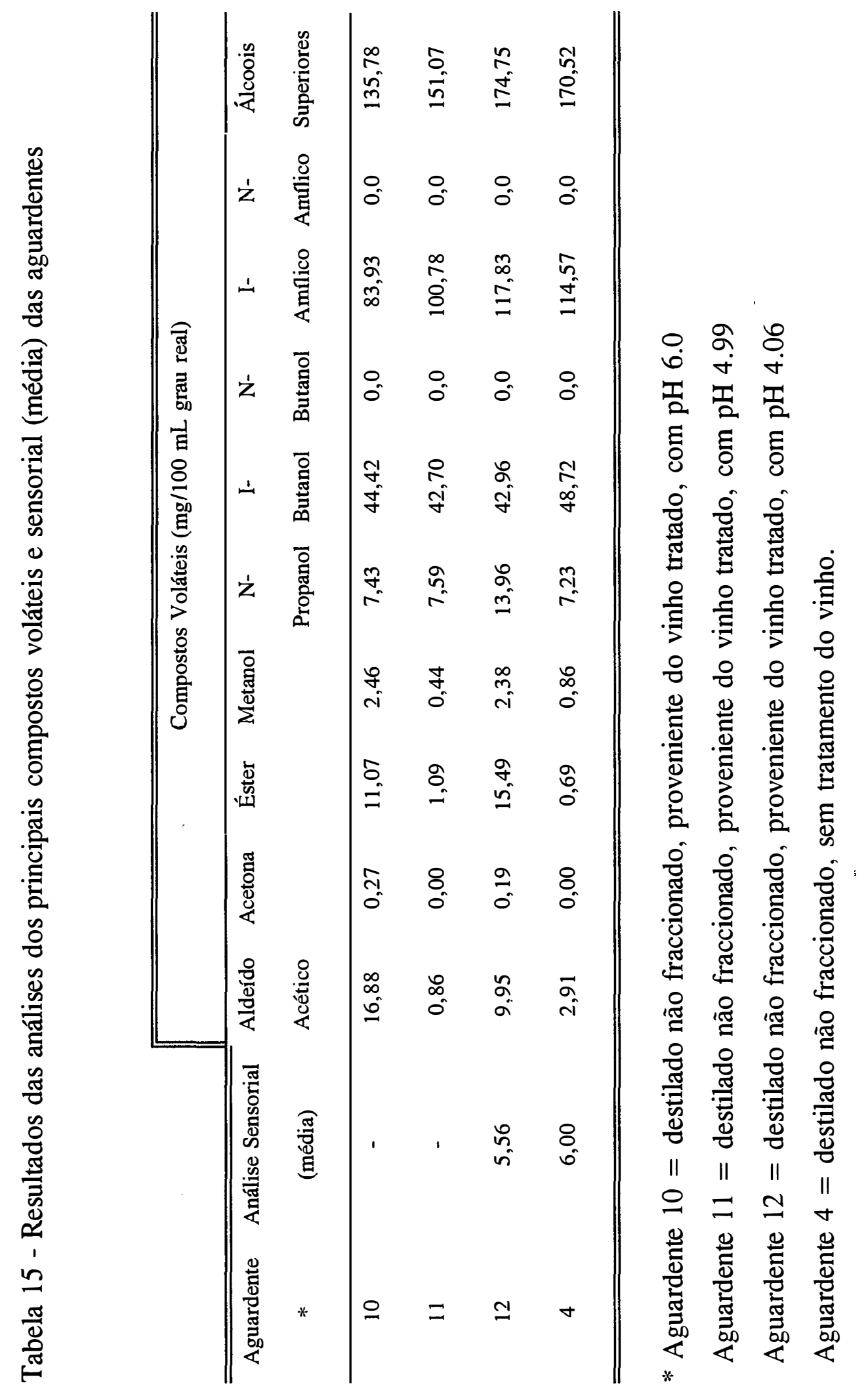


Segundo Guymon (1950) ${ }^{18}$ citado por Williams \& Strauss (1976), o tratamento das frações cabeça de destilados com soda cáustica, peróxido de hidrogênio e/ou permanganato de potássio, resulta um produto de qualidade inferior ao não tratado. O tratamento da fração cabeça resultante da destilação de vinhos com base, pode produzir por condensação de aldeídos, aldeídos superiores insaturados (ex: crotonaldeído) os quais confere um off-odour à bebida destilada, sendo recomendável a remoção prévia do acetaldeído (PE $20^{\circ} \mathrm{C}$ ) por métodos físicos (Williams \& Strauss, 1976; Morrisson \& Boyd, 1973).

$$
\begin{aligned}
& 2 \mathrm{CH}_{3} \mathrm{CHO} \stackrel{\mathrm{OH}^{-}}{\longrightarrow} \mathrm{CH}_{3} \mathrm{CHOHCH}_{2} \mathrm{CHO} \longrightarrow \mathrm{CH}_{3} \mathrm{CH}=\mathrm{CHCHO}+\mathrm{H}_{2} \mathrm{O} \\
& \text { acetaldeído 3-hidroxibutanal crotonaldeído }
\end{aligned}
$$

$\left(\mathrm{PE} 103^{\circ} \mathrm{C}\right)$

A acetalização, reação em meio ácido altamente favorável quanto a atenuar o odor pungente dos aldeídos, com a neutralização parcial dos vinhos pode ocorrer em menor extensão, em consequência das reações de condensação de aldeídos, bem como das reações de neutralização de ácidos (Morisson \& Boyd, 1973; Williams \& Strauss, 1975).

$\mathrm{O}$ tratamento dos vinhos com $\mathrm{Ca}(\mathrm{OH})_{2}$ pode influir no nível de produtos de adição de compostos carbonilos com sulfito de hidrogênio, pois segundo Amerine et al. (1972), o pH do vinho influencia na distribuição das espécies básicas e ácidas do ácido sulfuroso $\left(\mathrm{H}_{2} \mathrm{SO}_{3}\right)$, a $\mathrm{pH} 4,0$ predomina bissulfito, a $\mathrm{pH}$ 5,0 as espécies bissulfito e sulfito estão em igual proporção e a pH 6,0 predomina a forma sulfito, assim a medida que aumenta-se o pH dos vinhos, aumenta a concentração de aldeídos livres no meio. O sulfito, agente redutor sob condições oxidantes, forma

\footnotetext{
${ }^{18}$ GUYMON, J.F.; HALPERIN, Z.; CRAWFORD, C. Proceedings American Society of Enologists, 1950. p. 86. Apud WILLIAMS, P.J. \& STRAUSS, C.R. A treatment of grape wine distillation heads. Journal of the Science of Food and Agriculture, v.27, n.6, p.487-98, 1976.
} 
ácido sulfúrico e sulfato (Pauling, 1966), o que poderia justificar os valores de acidez e teor de aldeído acético obtidos para a aguardente 10 .

\subsubsection{Células de leveduras no vinho}

Os resultados analíticos e de condução do ensaio estão mostrados nas Tabelas 16, 17, 18 e 19 .

Tabela 16 - Valores de Brix dos caldos de cana e dos mostos, teor alcoólico, acidez volátil e $\mathrm{pH}$ dos vinhos tratados com $\mathrm{Ca}(\mathrm{OH})_{2}$.

\begin{tabular}{|c|c|c|c|c|c|c|}
\hline \multirow{2}{*}{$\underset{*}{\text { Aguardente }}$} & \multirow{2}{*}{$\begin{array}{c}{ }^{\circ} \text { Brix } \\
\text { Caldo de Cana }\end{array}$} & \multirow{2}{*}{$\begin{array}{l}{ }^{\circ} \text { Brix } \\
\text { Mosto }\end{array}$} & \multirow{2}{*}{$\begin{array}{c}\text { Álcool vinho } \\
(\% \mathrm{v})\end{array}$} & \multirow{2}{*}{$\begin{array}{c}\text { Acidez Volátil } \\
\text { Vinho } \\
\text { mgHAc/100 mL }\end{array}$} & \multicolumn{2}{|c|}{$\mathrm{pH}$ vinho } \\
\hline & & & & & inicial & fïnal \\
\hline 13 & 22,8 & 14,4 & 7,9 & 21,21 & - & - \\
\hline 12 & 19,4 & 14,5 & 8,34 & 16,08 & 3,39 & 4,06 \\
\hline 14 & 19,4 & 14,4 & 8,50 & 16,20 & 3,39 & 4,00 \\
\hline 4 & 23,0 & 14,4 & 8,2 & 11,4 & - & - \\
\hline
\end{tabular}

* OBS: Ver observação sob a Tabela 19.

Tabela 17 - Valores do teor alcoólico e volume dos destilados.

\begin{tabular}{ccc}
\hline \hline Aguardente & $\begin{array}{c}\text { Volume do destilado } \\
(\mathrm{mL})\end{array}$ & $\begin{array}{c}\text { Álcool Destilado } \\
(\% \mathrm{v})\end{array}$ \\
\hline 13 & 1600 & 51,38 \\
12 & 1600 & 49,11 \\
14 & 1600 & 49,01 \\
4 & 1600 & 52,48 \\
\hline \hline
\end{tabular}


Tabela 18 - Acidez total, grau alcoólico e análise sensorial (média) das aguardentes.

\begin{tabular}{cccc}
\hline \hline Aguardente & $\begin{array}{c}\text { Ácidez Aguardente } \\
(\mathrm{mg} \mathrm{HAc} / 100 \mathrm{~mL})\end{array}$ & $\begin{array}{c}\text { Álcool Aguardente } \\
(\% \mathrm{v})\end{array}$ & $\begin{array}{c}\text { Análise Sensorial } \\
(\mathrm{média})\end{array}$ \\
\hline 13 & 3,39 & 40,40 & 5,12 \\
12 & 2,92 & 39,91 & 5,56 \\
14 & 2,82 & 40,16 & 5,06 \\
4 & 2,34 & 39,34 & 6,0 \\
\hline \hline
\end{tabular}

Segundo Arroyo (1942), impurezas nitrogenadas decantadas e suspensas ou substâncias fixas, facilmente decompostas pela ação do calor, exercem influência sobre o destilado de maneira adversa, sendo o odor foul (hogo ou tufo) frequentemente presente em rum recém-destilado; tal odor tem sua origem na decomposição dessas substâncias nitrogenadas do vinho, durante a destilação. Lees (1943) estudando a influência de substâncias nitrogenadas sobre as características do destilado alcoólico, observou que o destilado obtido a partir de hidromel defecado apresentou-se de aroma e sabor "mais franco", "mais limpo", com menos "tufo" ou aroma indesejável e recomenda a utilização de centrífugas na clarificação de vinhos destinados à produção de bebidas alcoólicas em escala industrial. Almeida et al. (1947), recomenda coar muito bem o vinho, para livrá-lo de substâncias em suspensão, que possam contribuir indiretamente para a elevação do ponto de ebulição, que poderia resultar em saponificação parcial de ésteres, em consequência do aumento da temperatura em meio ácido. Parece-nos contraditória a afirmação anterior, já que a reação de saponificação ocorre em meio alcalino. 


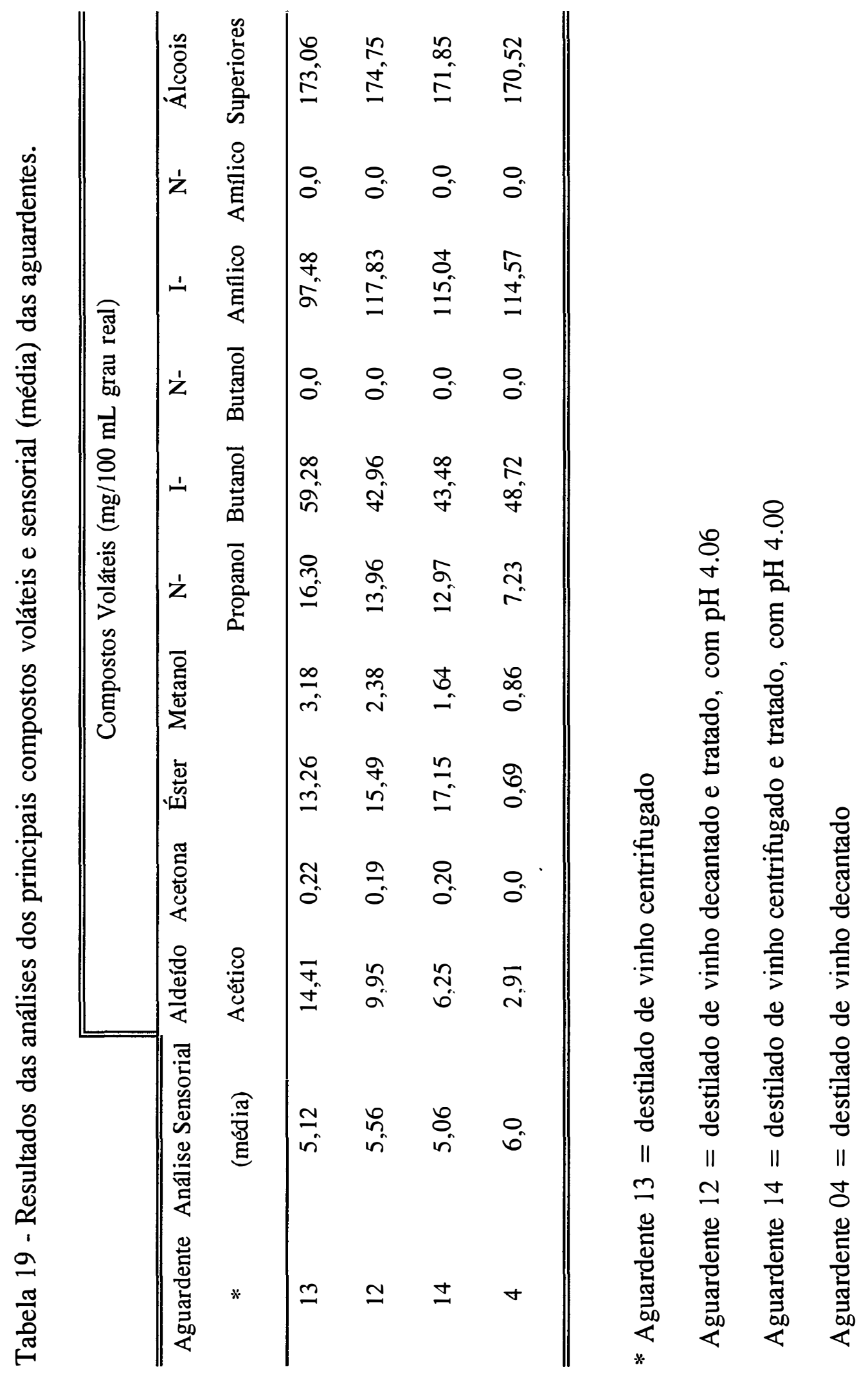


No estudo da influência da presença de células de leveduras no destilado, utilizaram-se 2 sistemas de remoção do fermento, tendo sido a aguardente 13, proveniente de vinho centrifugado considerada de qualidade inferior em relação à aguardente-referência, oriunda de vinho decantado (vide Tabela 18).

Segundo Sachavo (1977), a qualidade do brandy é melhorada se ao vinho forem adicionados de 1 a $20 \%$ de yeast wine antes da destilação, resultando um produto enriquecido por ésteres. Carnacini et al. (1989) afirmam que o conteúdo de lees no vinho influencia a composição, o aroma e o corpo do destilado, sendo que a concentração de lees no vinho utilizado depende das características desejadas no produto final. No caso do armagnac, o vinho contendo de 8 a $9 \%$ em volume de etanol é armazenado sobre lees, sendo essa removida antes da destilação, em contraste ao cognac, cujo vinho é levado ao alambique com concentração de lees $\leq$ 8\% (Reed \& Nagodawithana, 1991; Amerine et al., 1972).

Segundo Nykänen et al. (1977), lees (borra ou lodo), material em suspensão e/ou sedimentado em vinhos é composto principalmente por células de leveduras, sob o vapor de destilação dá origem a um produto oleoso denominado óleo de lees, que tem o aroma característico do cognac, produto este constituído principalmente de caprato, laurato e caprilato de etila. Suomalainen et al. (1974) relatam que ácidos lipofílicos como láurico, palmítico, palmitoléico, esteárico, oléico, podem aparecer em grandes concentrações na bebida, quando destilada na presença de células.

Comparando a acidez total das aguardentes 13 e 4, verificamos que na aguardente 13 apresenta-se maior em relação à $4(3,39$ e $2,34 \mathrm{mg} \mathrm{H} \mathrm{Ac} / 100 \mathrm{~mL}$, respectivamente) diferença essa que pode ser atribuída principalmente à diferença de acidez volátil entre os respectivos vinhos, do que ao aumento de ácidos lipofílicos no destilado, pois esses são ácidos fracos, conforme dados na Tabela 18. 
$\mathrm{Na}$ análise dos principais compostos voláteis das aguardentes 13 e 4 (Tabela 19), verificou-se maior concentração de aldeído acético (PE $\left.21^{\circ} \mathrm{C}\right)$, acetona $\left(\mathrm{PE} 56^{\circ} \mathrm{C}\right.$ ) e de éster (Acetato de etila, PE $77^{\circ} \mathrm{C}$ ) na aguardente 13, cujas concentrações obtidas foram 14,41 e 2,$91 ; 0,22$ e 0,$0 ; 13,26$ e $0,69 \mathrm{mg} / 100 \mathrm{~mL}$ grau real, respectivamente. Esses valores são discordantes de Carnacini et al. (1989) que relatam um efeito absorvente do lees sobre os compostos de baixo ponto de ebulição. Com relação à concentração de álcoois superiores, não se verificou variação significativa entre as aguardentes $12,13,14$ e 4 , resultado semelhante ao obtido por Marly-Brugerolle et al. (1978), entretanto, Lees (1943) obteve maior concentração de álcoois superiores em destilado a partir do vinho não centrifugado.

Segundo Sisakyan et al. (1972), análises de vinhos antes e durante a destilação e as análises dos extratos solúveis demonstraram que a proteína total e o N-carboxilico decrescem durante a destilação. Em consequência da hidrólise protéica, o conteúdo de tirosina, glicina, ácido glutâmico, alanina e prolina aumentam no destilado, portanto os compostos nitrogenados participam da formação de importantes compostos voláteis, componentes do flavor do brandy. Mndzhoyan et al. (1972) afirmam que a adição de autolizados de leveduras de panificação, leveduras de vinho ou sherry, imediatamente antes da destilação, aumentam as concentrações de álcoois superiores e ésteres no destilado e melhoram o flavor do brandy obtido.

A extensão da autólise das leveduras é influenciada por vários fatores, sendo que a concentração de etanol não inibe a autólise, enquanto a valores maiores de $\mathrm{pH}$ do meio ocorre maior liberação de nitrogênio e o aumento de temperatura pode favorecer em certa extensão o grau de autólise, por tratar-se de um fenômeno enzimático (Feuillat \& Charpentier, 1982; Vosti \& Joslyn, 1954). 
As aguardentes 12 e 14, provenientes de vinho decantado e centrifugado, respectivamente, foram tratados com $\mathrm{Ca}(\mathrm{OH})_{2}$ a pH 4,06 e 4,00 e quando submetidas à análise sensorial, as aguardentes 12 e 14 obtiveram médias de notas inferiores à média 6,0, atribuída à aguardente-referência quanto ao atributo flavor.

\subsubsection{Remoção de compostos voláteis da matéria-prima no vinho}

Os resultados analíticos e de condução do ensaio estão mostrados nas Tabelas 20, 21, 22 e 23 .

Tabela 20 - Valores de Brix dos caldos de cana e dos mostos, teor alcoólico e acidez volátil dos vinhos.

\begin{tabular}{ccccc}
\hline \hline Aguardente* & $\begin{array}{c}{ }^{\circ} \text { Brix } \\
\text { Caldo de Cana }\end{array}$ & $\begin{array}{c}{ }^{\circ} \text { Brix } \\
\text { Mosto }\end{array}$ & $\begin{array}{c}\text { Álcool vinho } \\
(\% \mathrm{v})\end{array}$ & $\begin{array}{c}\text { Acidez Volátil } \\
\text { Vinho } \\
\text { mgHAc/100 mL }\end{array}$ \\
\hline 13 & 22,8 & 14,4 & 7,90 & 21,21 \\
15 & 21,7 & 14,5 & 8,92 & 16,54 \\
16 & 23,1 & 14,6 & 9,08 & 16,50 \\
4 & 23,0 & 14,4 & 8,20 & 11,40 \\
\hline \hline
\end{tabular}

* OBS: Ver observação sob a Tabela 23. 
Tabela 21 - Valores do teor alcoólico e volume dos destilados.

\begin{tabular}{ccc}
\hline \hline Aguardente & $\begin{array}{c}\text { Volume Destilado } \\
(\mathrm{mL})\end{array}$ & $\begin{array}{c}\text { Álcool Destilado } \\
(\% \mathrm{v})\end{array}$ \\
\hline 13 & 1600 & 51,38 \\
15 & 1600 & 52,58 \\
16 & 1600 & 51,79 \\
4 & 1600 & 52,48 \\
\hline
\end{tabular}

Tabela 22 - Acidez Total, Grau alcoólico e análise sensorial (média) das Aguardentes.

\begin{tabular}{cccc}
\hline \hline Aguardente & $\begin{array}{c}\text { Ácidez Aguardente } \\
(\mathrm{mg} \mathrm{HAc} / 100 \mathrm{~mL})\end{array}$ & $\begin{array}{c}\text { Álcool Aguardente } \\
(\% \mathrm{v})\end{array}$ & $\begin{array}{c}\text { Análise Sensorial } \\
(\text { média })\end{array}$ \\
\hline 13 & 3,39 & 40,40 & 5,12 \\
15 & 3,29 & 40,78 & 6,25 \\
16 & 3,29 & 40,16 & 5,19 \\
4 & 2,34 & 39,34 & 6,00 \\
\hline \hline
\end{tabular}




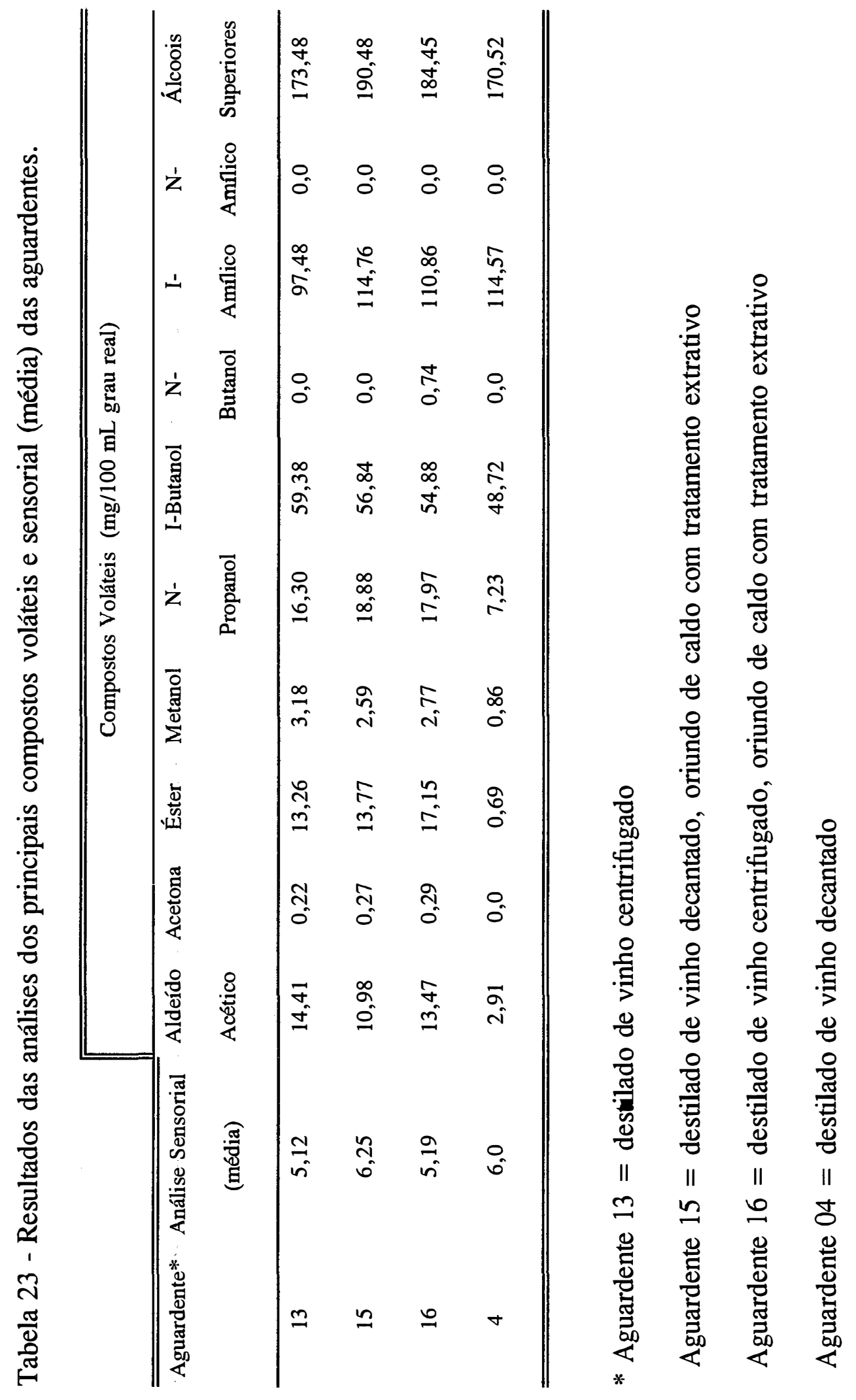


O caldo de cana é uma solução complexa contendo sacarose, açúcares redutores, ácidos orgânicos, matéria colorida, entre outros (Mane et al., 1992). Segundo Fournier \& Vidaurreta (1971), no mínimo nove diferentes ácidos carboxílicos são encontrados no caldo de cana-de-açúcar, sendo segundo o grau de abundância: aconítico, cítrico, málico, oxálico, glicólico, mesacônico, succínico, fumárico e siríngico.

A composição do caldo de cana depende da variedade da cana, das condições de cultivo e climáticas, do grau de maturação, do método de colheita, da técnica de extração. Portanto, para melhorar a qualidade de produtos fermentados a partir da cana-de-açúcar, uma cuidadosa compreensão de sua composição é necessária, pois esses componentes influem no metabolismo das leveduras e bactérias, afetando o perfil aromático do rum (Celestine-Myrtil \& Parfait, 1987). Mndzhoyan \& Saakyan (1972) realizaram um estudo comparativo de terpenos em extratos de uvas, vinhos e brandy e mostraram que compostos presentes em uvas (linalool, B-ionona, geraniol e outros compostos não identificados) passam para os vinhos e destilados. Enquanto Strauss \& Williams (1983) demonstraram a importância dos compostos resultantes de reações de hidrólise de monoterpenos presentes na uva, durante a destilação, para a composição do flavor de brandy.

No presente estudo, na obtenção da aguardente 15 , efetuamos uma préextração do caldo de cana com etanol a $8 \%$ em volume, mantendo a mesma relação entre o material extraível e extrator (etanol) através da diluição do caldo de cana a um teor de sólidos solúveis de 14,8 a $14,9^{\circ}$ Brix, para verificar possível influência de compostos presentes na matéria-prima sobre o destilado. A aguardente 15 foi considerada superior, quanto ao atributo flavor, em relação à aguardente-referência, enquanto a aguardente 16, oriunda de vinho centrifugado e de caldo de cana submetido a pré-extração com etanol, foi considerada inferior. 
As aguardentes 15 e 16 apresentaram acidez proporcionais aos vinhos originários, superior ao da aguardente-referência, conforme Tabela 22, enquanto os resultados da análise cromatográfica dos principais compostos voláteis (conforme Tabela 23), demonstraram maior concentração de n-propanol nas aguardentes 15 e $16 ; 18,88$ e $17,97 \mathrm{mg} / 100 \mathrm{~mL}$ grau real respectivamente, em relação à aguardentereferência $(7,23 \mathrm{mg} / 100 \mathrm{~mL}$ grau real).

Tokitomo et al. (1984) investigaram os componentes do aroma de caldo e de melaço de cana-de-açúcar e identificaram compostos entre os quais 4nonanolide, 4-vinil-fenol e 4-hidroxi-3-methoxibenzaldeído como componentes do aroma do caldo de cana e também compostos voláteis, formados a partir do aquecimento do açúcar como 3-hidroxi-2-metil-4-piranona e 2-hidroxi-3-metil-2ciclopentenona. A metodologia utilizada no preparo da amostra foi extração líquidolíquido com éter por 40 horas do caldo de cana, condições de extração bastante diferenciadas daquelas sob as quais foi conduzido o presente estudo.

O tratamento extrativo prévio do caldo de cana na obtenção da aguardente 15 , refletiu positivamente em suas características sensoriais, enquanto na aguardente 16, possivelmente o efeito da centrifugação do vinho tenha sido determinante na avaliação sensorial da aguardente. Porém, as substâncias extraídas no tratamento do caldo e que influiram no flavor da aguardente, não foram possíveis de serem identificadas pelo cromatógrafo, já que estas não eram conhecidas e portanto, não faziam parte do padrão utilizado e nem do sistema de detecção.

\subsubsection{Teor alcoólico do vinho}

Os resultados analíticos e de condução do ensaio estão mostrados nas Tabelas 24, 25, 26 e 27. 
Tabela 24 - Valores de Brix dos caldos de cana e dos mostos, teor alcoólico e acidez volátil dos vinhos.

\begin{tabular}{ccccc}
\hline $\begin{array}{c}\text { Aguardente } \\
*\end{array}$ & $\begin{array}{c}{ }^{\circ} \text { Brix } \\
\text { Caldo de Cana }\end{array}$ & $\begin{array}{c}{ }^{\circ} \text { Brix } \\
\text { Mosto }\end{array}$ & $\begin{array}{c}\text { Álcool vinho } \\
(\% \mathrm{v})\end{array}$ & $\begin{array}{c}\text { Acidez Volátil } \\
\text { Vinho } \\
\text { mgHAc/100 mL }\end{array}$ \\
\hline 18 & 22,8 & 18,9 & 10,24 & 24,24 \\
4 & 23,0 & 14,4 & 8,20 & 11,40 \\
\hline \hline
\end{tabular}

* OBS: Vide observação sob a Tabela 27.

Tabela 25 - Valores do teor alcoólico e volume dos destilados.

\begin{tabular}{ccc}
\hline Aguardente & $\begin{array}{c}\text { Volume do Destilado } \\
(\mathrm{mL})\end{array}$ & $\begin{array}{c}\text { Álcool Destilado } \\
(\% \mathrm{v})\end{array}$ \\
\hline 18 & 1600 & 62,66 \\
4 & 1600 & 52,48 \\
\hline
\end{tabular}

Tabela 26 - Acidez total, grau alcoólico e análise sensorial (média) das aguardentes.

\begin{tabular}{cccc}
\hline Aguardente & $\begin{array}{c}\text { Ácidez Aguardente } \\
(\mathrm{mg} \mathrm{HAc} / 100 \mathrm{~mL})\end{array}$ & $\begin{array}{c}\text { Álcool Aguardente } \\
(\% \mathrm{v})\end{array}$ & $\begin{array}{c}\text { Análise Sensorial } \\
(\mathrm{média})\end{array}$ \\
\hline 18 & 3,13 & 40,34 & 7,31 \\
04 & 2,34 & 39,34 & 6,0 \\
\hline
\end{tabular}




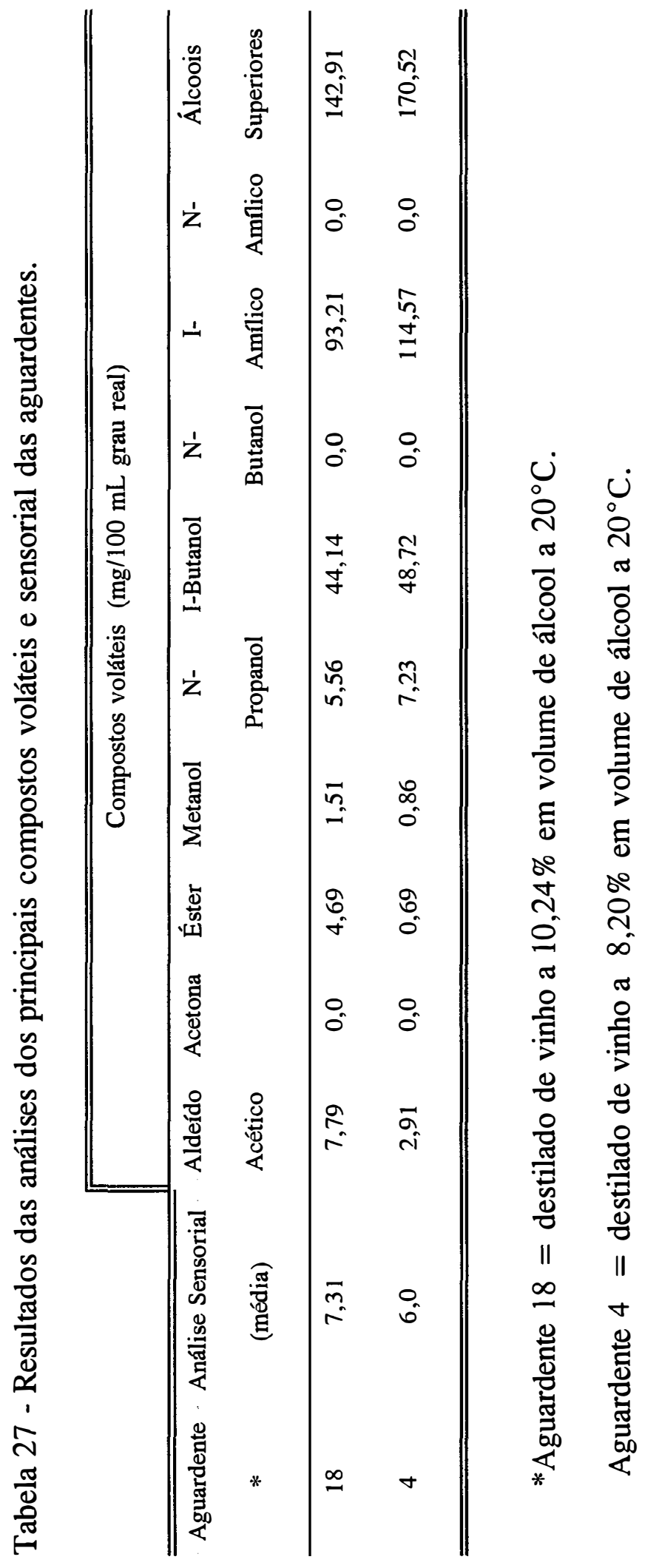


A eficiência da destilaria tem como índice básico a quantidade de aguardente produzida na destilação em relação à quantidade usada da fonte de carboidrato. Novaes et al. (1974) citam que mostos muito diluídos facilitam a fermentação, tornando-a mais rápida e completa, diminuem as incrustações, facilitando a limpeza dos aparelhos; em contraposição, requerem um maior volume de dornas e depósitos, aumentam os consumos de água e de vapor, bem como diminuem o rendimento dos equipamentos de destilação.

A aguardente 18 oriunda de vinho cuja concentração de álcool em volume de $10,24 \%$ a $20^{\circ} \mathrm{C}$, foi considerada superior em relação à aguardente-referência $\left(8,20 \%\right.$ em volume de álcool no vinho). Lafon et al. $(1964)^{19}$, citados por Simpson (1971), afirmam que o melhor vinho para cognac provém de vindima sadia e tem um conteúdo de álcool etílico em volume a $20^{\circ} \mathrm{C}$, menor que $10,5 \% \mathrm{v}$.

Gutierrez (1993), estudando a produção de álcoois superiores por linhagens de Saccharomyces durante a fermentação alcoólica, verificou que com o aumento da concentração de sacarose, ocorreu maior produção de álcoois isoamílico e isobutílico pelas leveduras da panificação "Fleischmann". Klosowsky \& Czuprynski (1993) afirmam que a ótima concentração de açúcares nas fermentações é 12-14\% e maior concentração de açúcar produz mais aldeídos e álcoois superiores

${ }^{19}$ LAFON, I. et al. "Le Cognac". Paris, Libr. J.B. Baillière \& Fils, 1964. Apud SIMPSON, A.C. Manufacture of brandy. Process Biochemistry, v.6, n.2, p.25-7, 1971. 
e menos ácidos orgânicos, na produção de bebida alcoólica destilada. Nykänen \& Nykänen (1991) relatam que o aumento da concentração de glicose no mosto resulta em aumento na concentração de ésteres.

Comparando a composição das aguardentes 18 e 4 (referência), quanto aos principais compostos voláteis, verificou-se que a aguardente 18 apresentou maior teor de aldeído acético, éster (acetato de etila) e menor concentração de álcoois superiores em relaçấo à aguardente-referência, conforme Tabela 27. No presente estudo, admitimos um rendimento de $13,3 \%$ de aguardente em relação ao volume de vinho destilado, assim, a concentração de álcool no destilado, na obtenção da aguardente 18 foi de $62,66 \%$ em volume a $20^{\circ} \mathrm{C}$, ou seja, maior volume das frações cabeça e coração comparado com a aguardente-referência.

Os resultados das análises físico-química e sensorial para aguardente comercial estão mostrados nas Tabelas 28 e 29.

Tabela 28 - Acidez total, grau alcoólico e análise sensorial (média) das aguardentes.

\begin{tabular}{cccc}
\hline $\begin{array}{c}\text { Aguardente } \\
*\end{array}$ & $\begin{array}{c}\text { Ácidez Aguardente } \\
(\mathrm{mg} \mathrm{HAc} / 100 \mathrm{~mL})\end{array}$ & $\begin{array}{c}\text { Álcool Aguardente } \\
(\% \mathrm{v})\end{array}$ & $\begin{array}{c}\text { Análise Sensorial } \\
(\text { média })\end{array}$ \\
\hline 17 & 11,85 & 37,07 & 4,81 \\
04 & 2,34 & 39,34 & 6,0 \\
\hline \hline
\end{tabular}

*OBS: Vide observação sob a Tabela 29. 


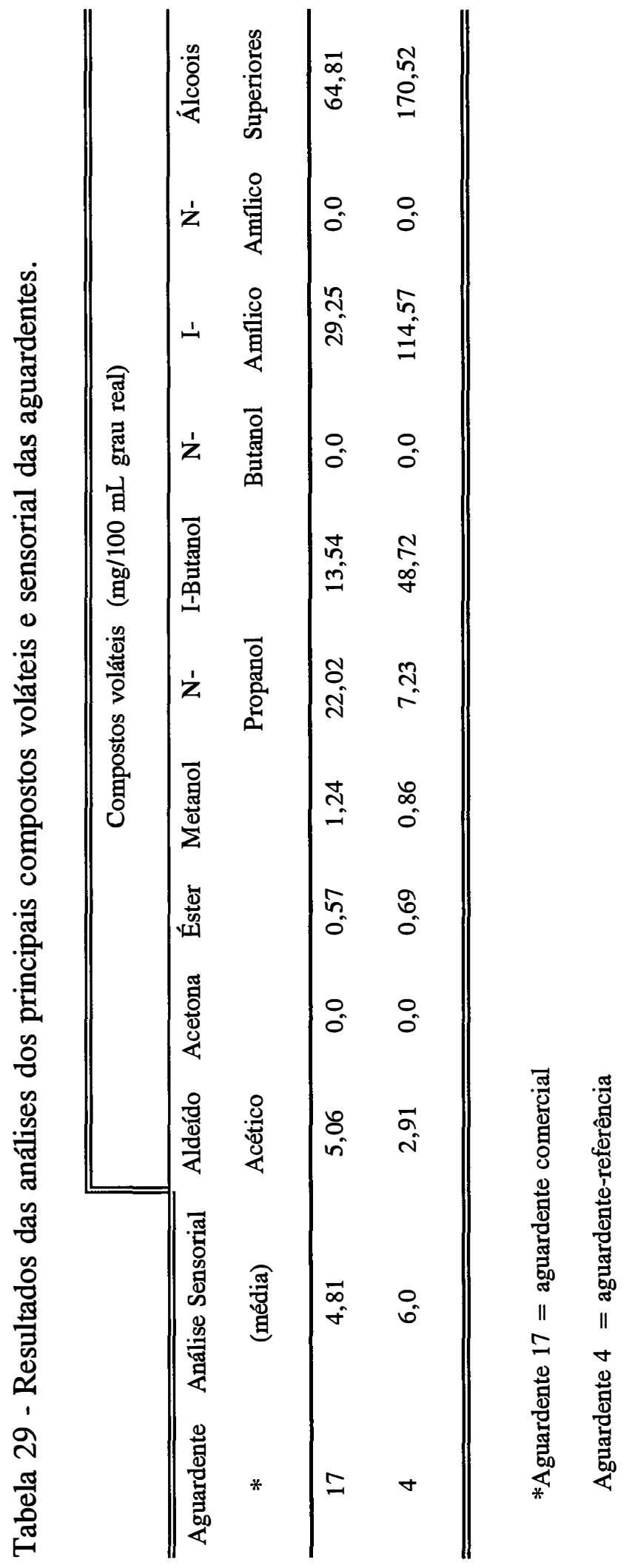


A aguardente 17 foi considerada inferior em relação à aguardentereferência. A aguardente apresentou maior acidez e a concentração de compostos voláteis maior quanto a aldeído acético, e menor quanto aos álcoois superiores em relação à aguardente-referência, conforme dados nas Tabelas 28 e 29.

\subsection{Efeito da redestilação sobre a qualidade da aguardente}

Os resultados analíticos e de condução do ensaio estão mostrados nas Tabelas 30, 31, 32 e 33 .

Tabela 30 - Valores de Brix dos caldos de cana e dos mostos, teor alcoólico e acidez volátil dos vinhos.

\begin{tabular}{ccccc}
\hline \hline $\begin{array}{c}\text { Aguardente } \\
* *\end{array}$ & $\begin{array}{c}{ }^{\circ} \text { Brix } \\
\text { Caldo de Cana }\end{array}$ & $\begin{array}{c}{ }^{\circ} \text { Brix } \\
\text { Mosto }\end{array}$ & $\begin{array}{c}\text { Álcool vinho } \\
(\% v)\end{array}$ & $\begin{array}{c}\text { Acidez Volátil } \\
\text { Vinho } \\
\text { mgHAc/100 mL }\end{array}$ \\
\hline 7 & 20,2 & 14,4 & 7,06 & 20,04 \\
8 & $20,0^{*}$ & $14,2^{*}$ & $7,77^{*}$ & $20,16^{*}$ \\
9 & $20,0^{*}$ & $14,2^{*}$ & $7,77^{*}$ & $20,16^{*}$ \\
4 & 23,0 & 14,4 & 8,20 & 11,40 \\
\hline \hline
\end{tabular}

* Valores Médios

** OBS: Ver observação sob a Tabela 33. 
Tabela 31 - Valores do teor alcoólico e volume dos destilados obtidos na segunda destilação.

\begin{tabular}{ccc}
\hline \hline Aguardente & $\begin{array}{c}\text { Volume do Destilado } \\
(\mathrm{mL})\end{array}$ & $\begin{array}{c}\text { Álcool Destilado } \\
(\% \mathrm{v})\end{array}$ \\
\hline 7 & 500 & 59,62 \\
8 & 4750 & 60,73 \\
9 & 2500 & 46,58 \\
4 & 1600 & 52,48 \\
\hline \hline
\end{tabular}

Tabela 32 - Acidez total, grau alcoólico e análise sensorial (média) das aguardentes.

\begin{tabular}{cccc}
\hline \hline Aguardente & $\begin{array}{c}\text { Ácidez Aguardente } \\
(\mathrm{mg} \mathrm{HAc} / 100 \mathrm{~mL})\end{array}$ & $\begin{array}{c}\text { Álcool Aguardente } \\
(\% \mathrm{v})\end{array}$ & $\begin{array}{c}\text { Análise Sensorial } \\
\text { (média) }\end{array}$ \\
\hline 7 & 1,62 & 41,89 & 4,25 \\
8 & 1,36 & 40,59 & 6,31 \\
9 & 1,30 & 39,59 & 6,12 \\
4 & 2,34 & 39,34 & 6,0 \\
\hline \hline
\end{tabular}




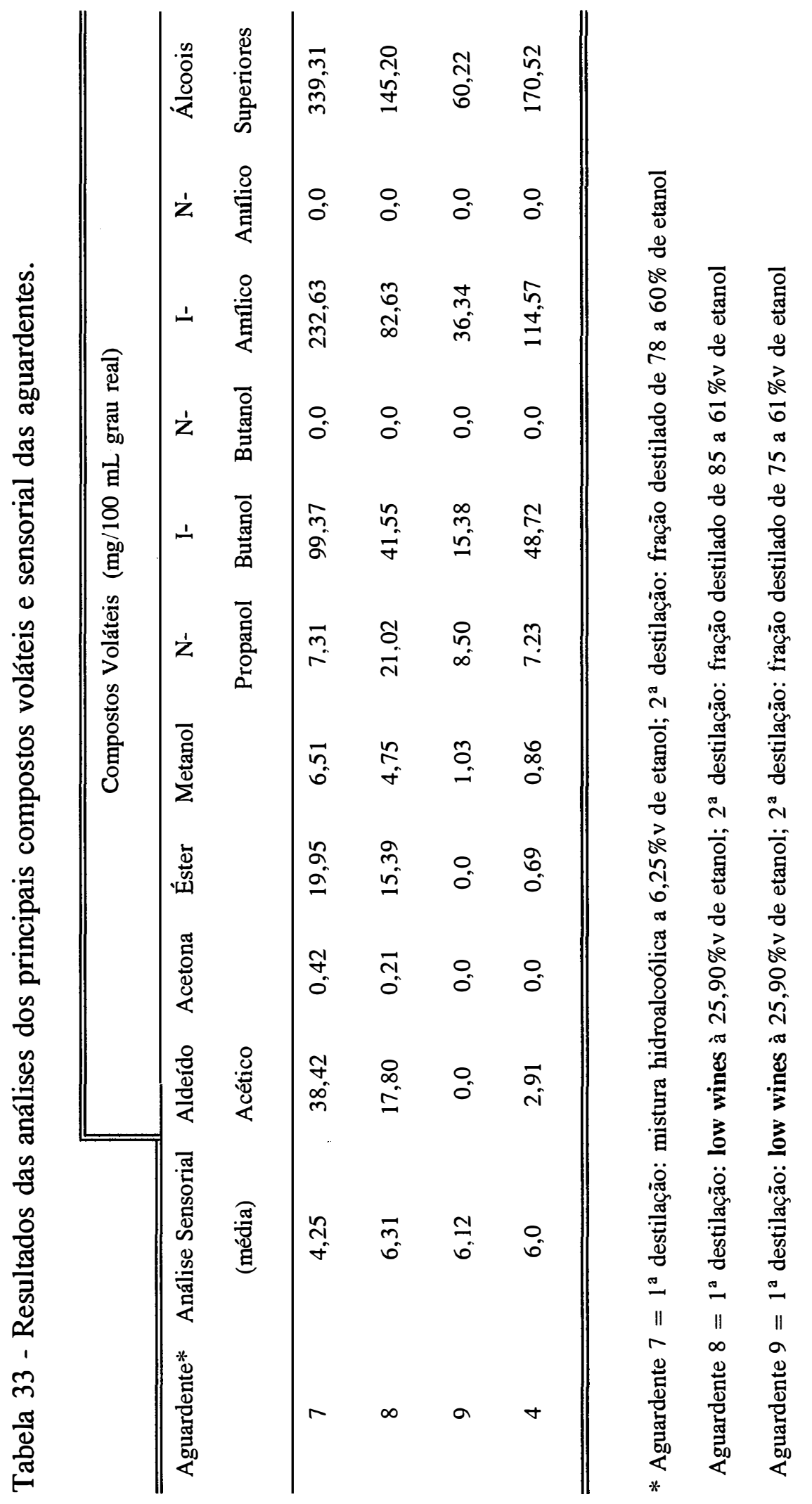


A aguardente 8 , resultante da fração do destilado que compreende os produtos que destilam durante a $2^{\mathrm{a}}$ destilação, de 84,79 a $61,05 \%$ álcool em volume a $20^{\circ} \mathrm{C}$ e a aguardente 9 , que compreende a fração que destila de 75,83 a $61,05 \%$ álcool em volume a $20^{\circ} \mathrm{C}$, quando submetidas à análise sensorial obtiveram uma média de notas superiores à média 6,0, atribuída à aguardente-referência em relação ao atributo flavor. O sistema de corte adotado durante a segunda destilação para a obtenção da aguardente 9 foi semelhante ao adotado para a obtenção de cognac, o qual é oriundo da fração que destila entre 75 a $60 \%$ álcool em volume (Léauté, 1990).

As aguardentes 8 e 9 apresentaram acidez total inferior à da aguardentereferência, 1,36 e 1,30 mg H Ac/100 mL respectivamente, versus 2,34 mg H Ac/100 $\mathrm{mL}$ na aguardente-referência. Em relação aos compostos voláteis, a aguardente 8 apresentou maior concentração quanto a todos compostos analisados em relação à aguardente 9, e ambas apresentaram-se em concentração de compostos voláteis distinta da aguardente-referência, conforme Tabela 33.

A compreensão do comportamento dos congêneres durante a destilação e do efeito desses sobre as características sensoriais do produto é fundamental na produção de aguardente de boa qualidade. Para obter o perfil do comportamento dos principais compostos voláteis durante a primeira e segunda destilação, procedeu-se o fracionamento dos destilados, sendo as frações recolhidas analisadas quanto a concentração dos principais compostos voláteis e acidez total. Na primeira destilação realizou-se o fracionamento até $42,61 \%$ de álcool em volume a $20^{\circ} \mathrm{C}$ e na segunda destilação até $51,89 \%$ de álcool em volume a $20^{\circ} \mathrm{C}$, conforme Tabelas $34,34(1)$ e 35 , 35(1), respectivamente. 


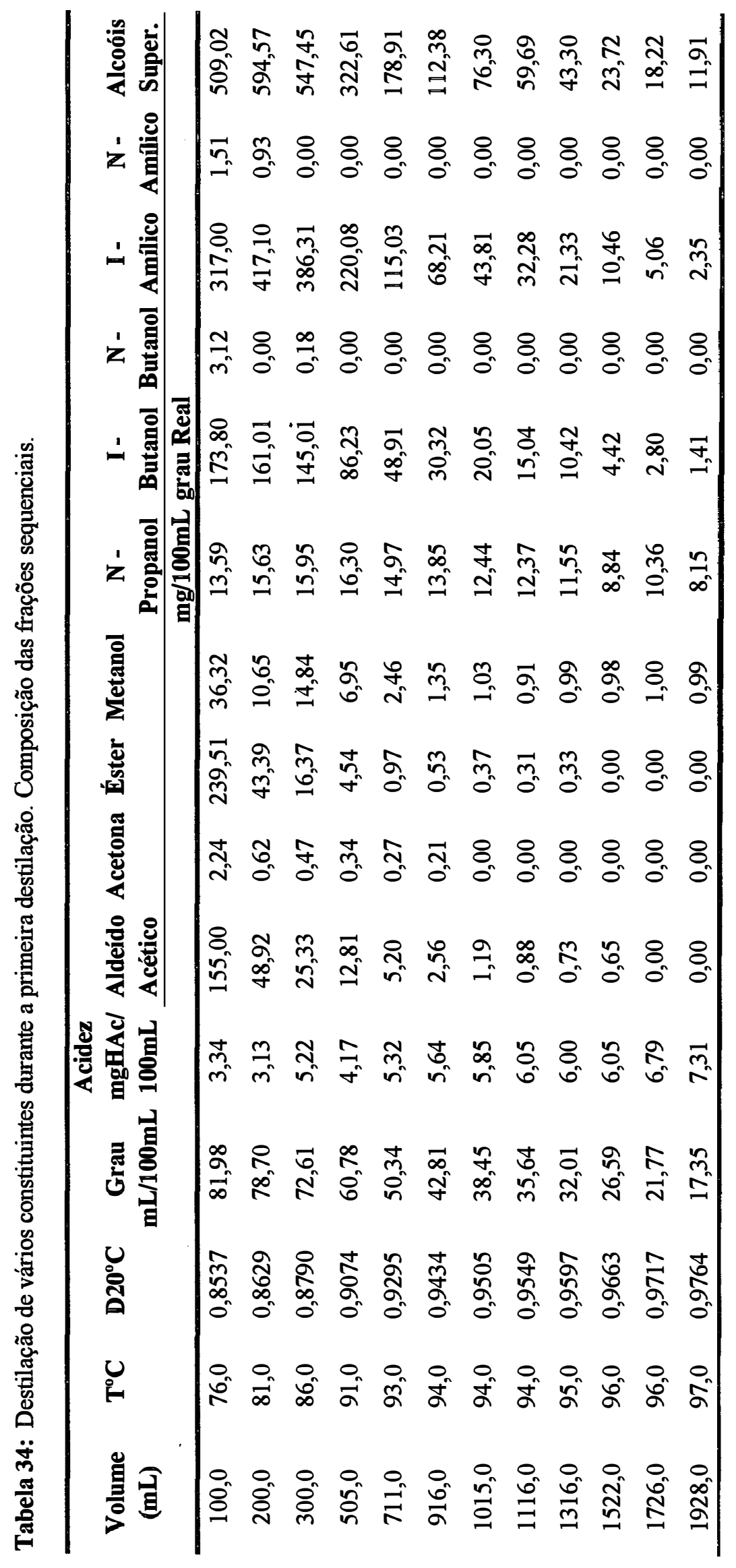




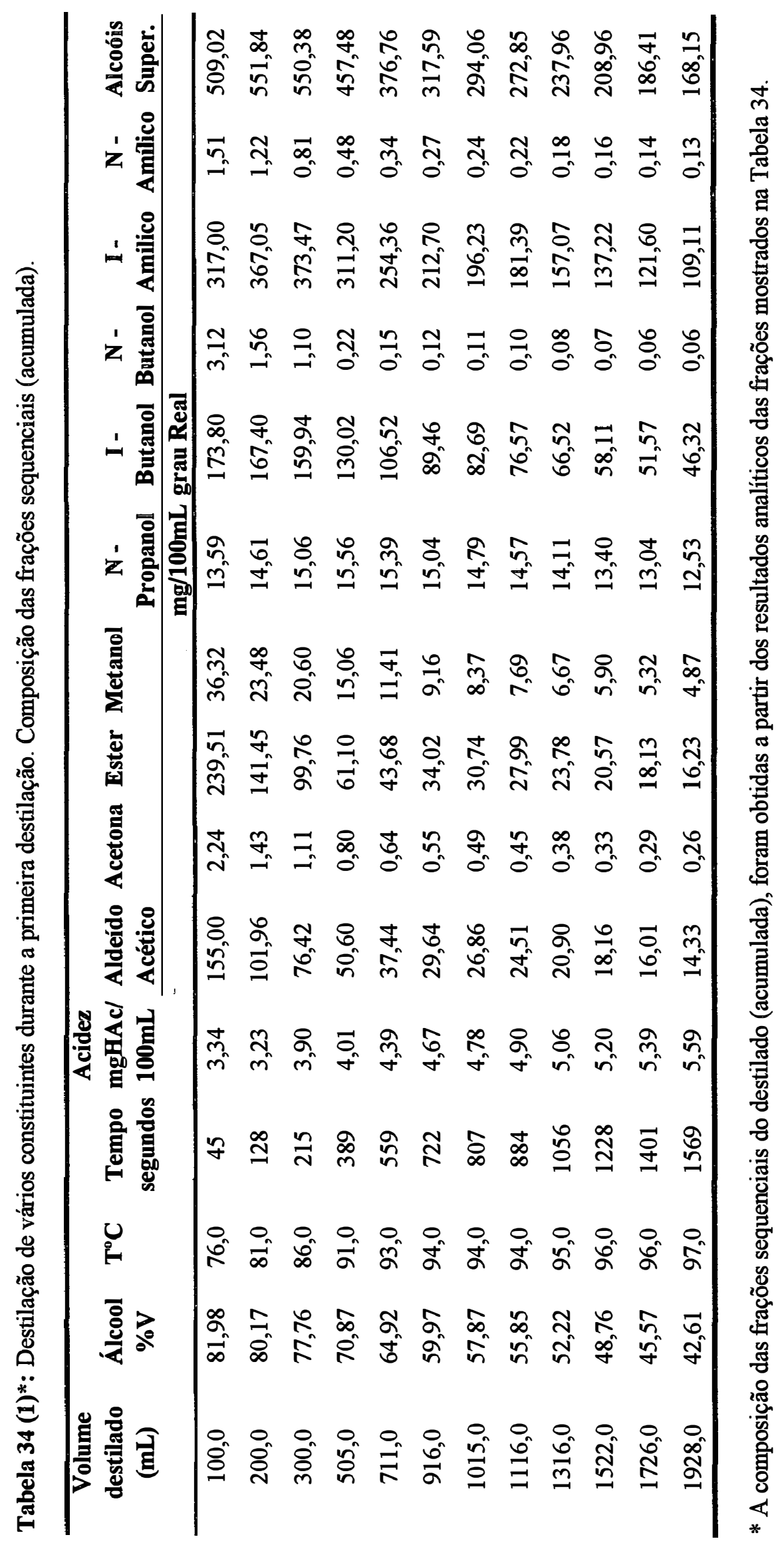




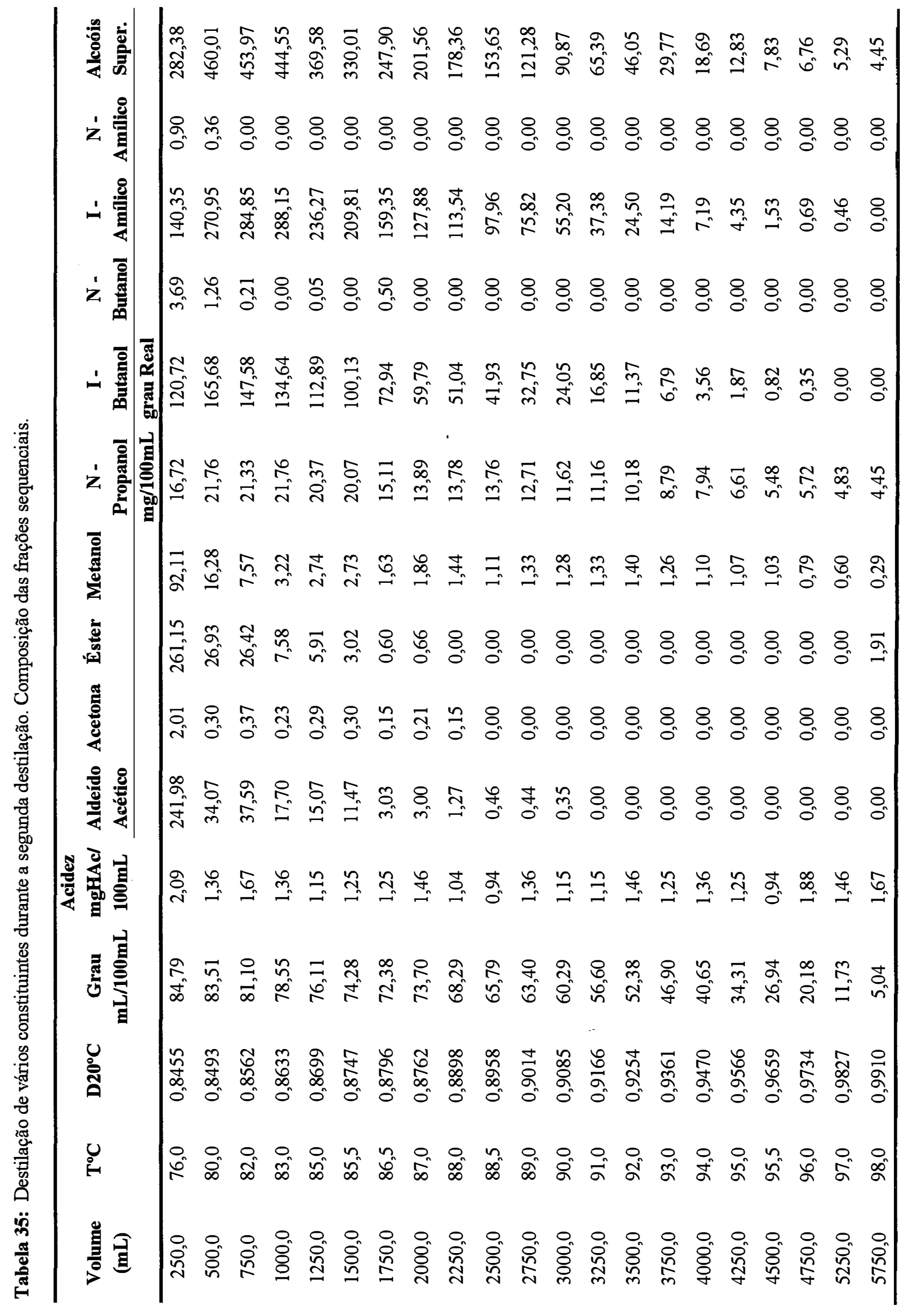




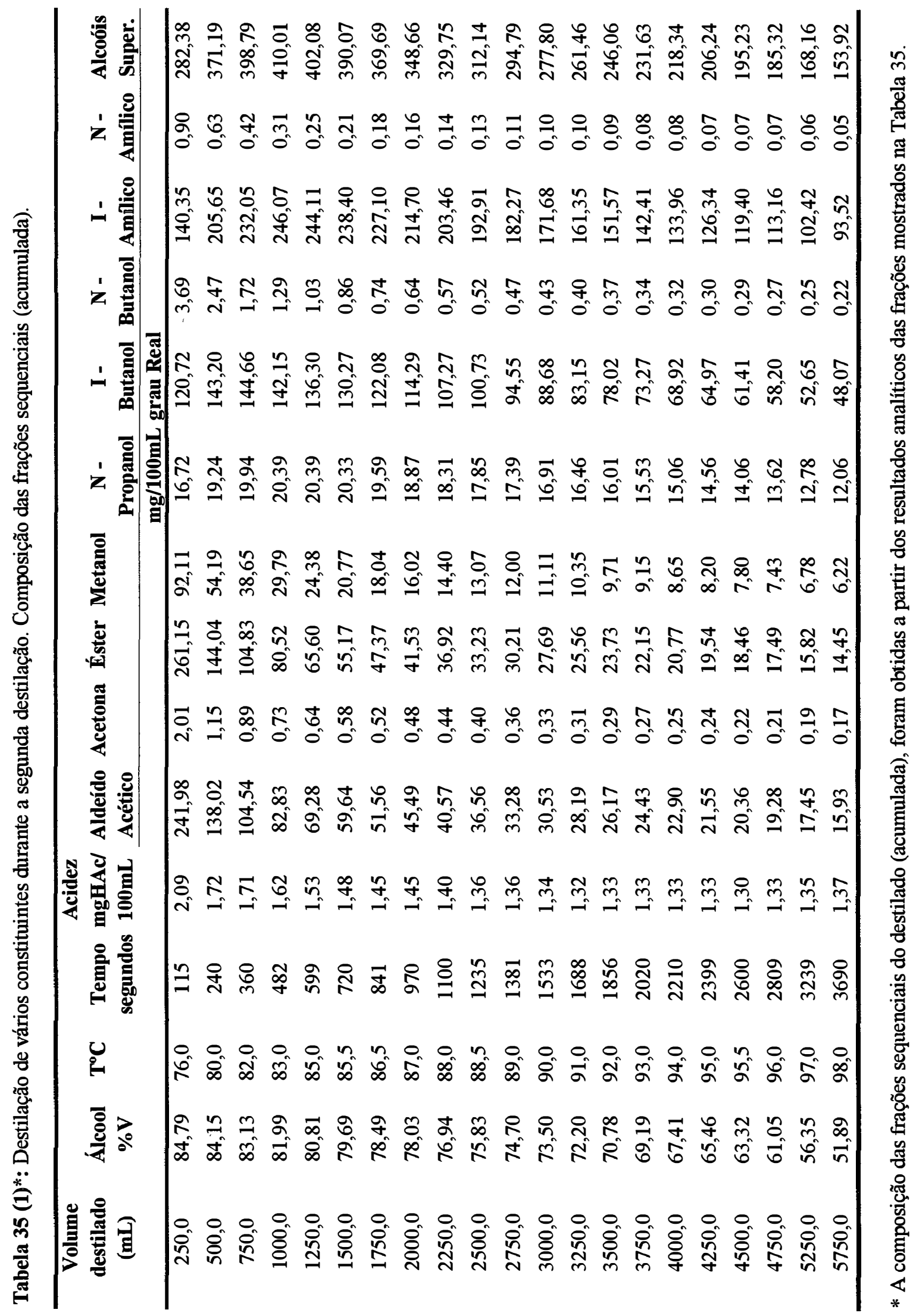


Durante a primeira destilação do vinho, cuja concentração alcoólica em volume era de $7,20 \%$ e a acidez volátil de $19,84 \mathrm{mg} \mathrm{H} \mathrm{Ac/100} \mathrm{mL,} \mathrm{observou-se} \mathrm{um}$ acentuado declínio da concentração de etanol em relação ao observado durante a segunda destilação, cujo low wines apresentava concentração alcoólica em volume de 25,90\%, conforme Figuras 4 e 5.

A concentração de ácidos, conforme Figura 6, aumenta durante a primeira destilação, enquanto compostos voláteis como aldeído acético (PE $\left.21^{\circ} \mathrm{C}\right)$, acetato de etila $\left(77^{\circ} \mathrm{C}\right)$, acetona $\left(\operatorname{PE~} 56^{\circ} \mathrm{C}\right)$ e metanol $\left(\mathrm{PE} 66^{\circ} \mathrm{C}\right)$, destilam no início, entre 81,98 a 72,61\% álcool em volume, que compreende a faixa de temperatura entre 76 a $86^{\circ} \mathrm{C}$, constituindo a fração cabeça, cujos pontos de ebulição são menores que o do etanol, conforme Figuras 7, 8 e 9.

A concentração de álcoois superiores declina durante a primeira destilação, sendo que o propanol destila mais uniformemente, enquanto o declínio mais acentuado é quanto a concentração de álcool isoamílico. Segundo Guymon (1974), esse álcool apresenta alto ponto de ebulição $\left(\mathrm{PE} 128^{\circ} \mathrm{C}\right)$ e alto peso molecular (PM 88,15) sendo menos volátil que etanol a alta graduação, pois é solúvel em etanol em todas as proporções, porém em água, na qual o álcool isoamílico é levemente solúvel $(3,6$ $\mathrm{g} / 100 \mathrm{~g} \mathrm{H}_{2} \mathrm{O}$ ), a volatilidade do álcool isoamílico aumenta acentuadamente a menor graduação. Assim, a distribuição desses congêneres é afetada por sua volatilidade e pela concentração de álcool, ou seja, alta volatilidade quando baixa solubilidade e viceversa (Figuras 10 e 11). 


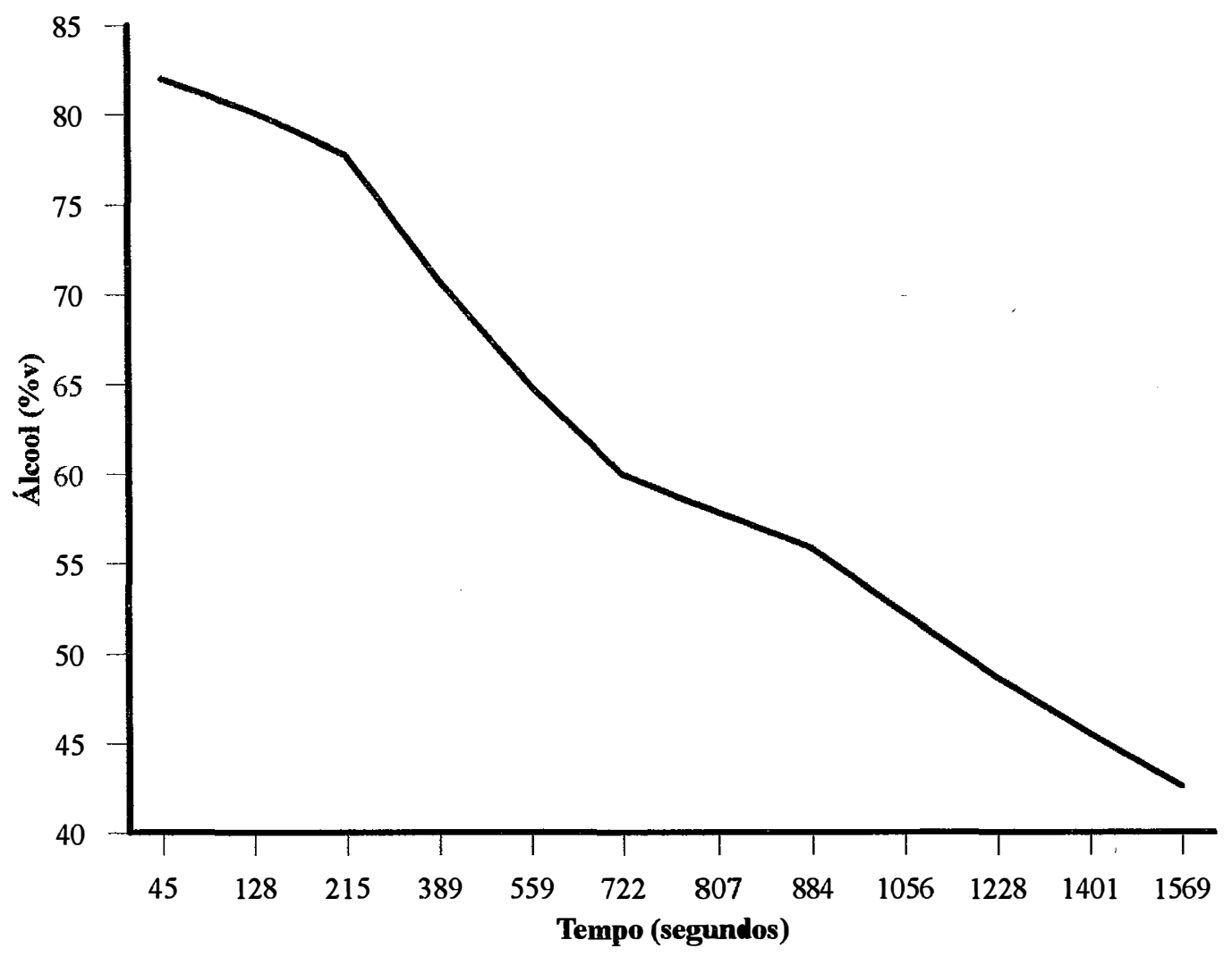

Figura 4 - Variação da concentração de etanol em função do tempo de destilação Primeira destilação. 


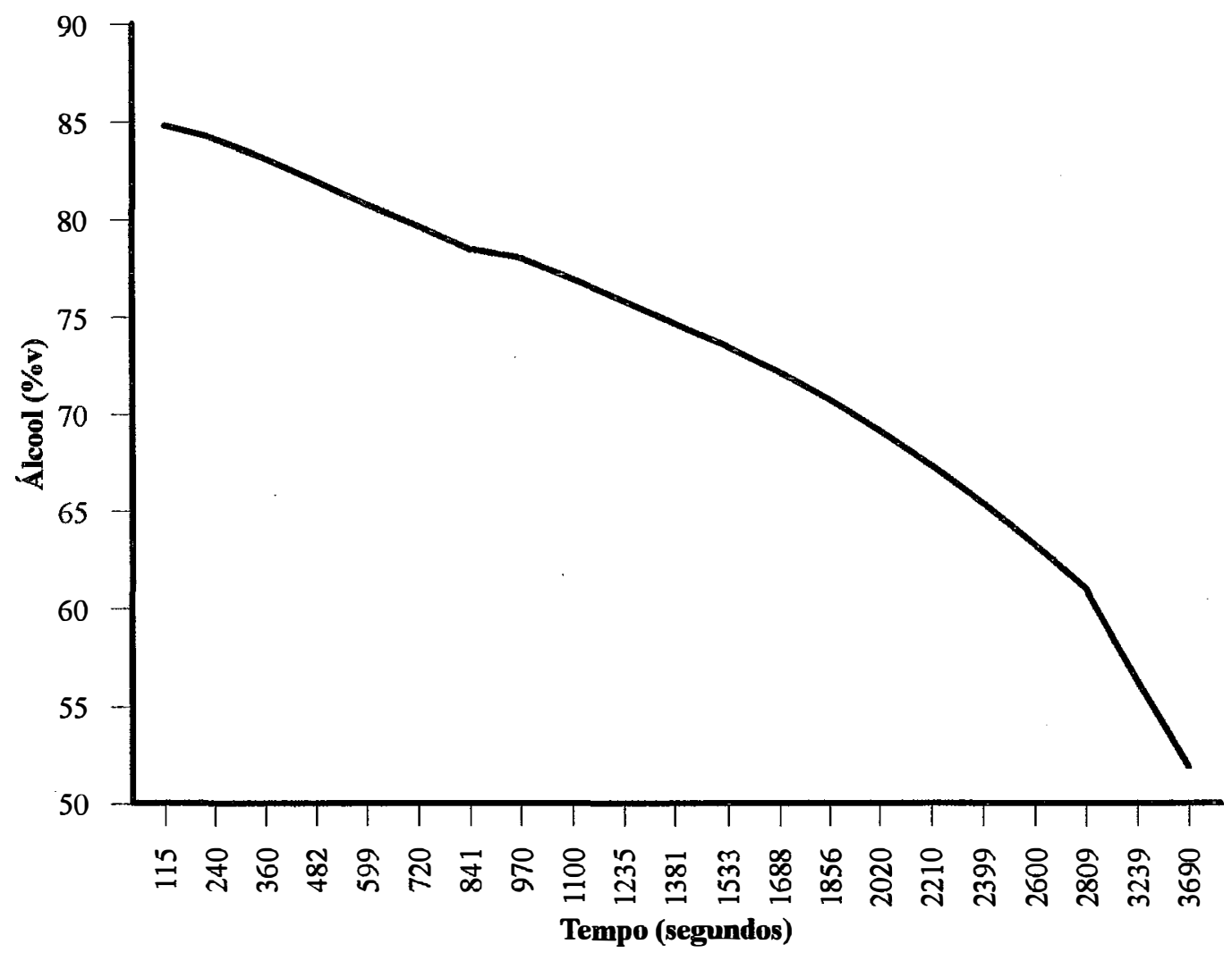

Figura 5 - Variação da concentração de etanol em função do tempo de destilação Segunda destilação. 


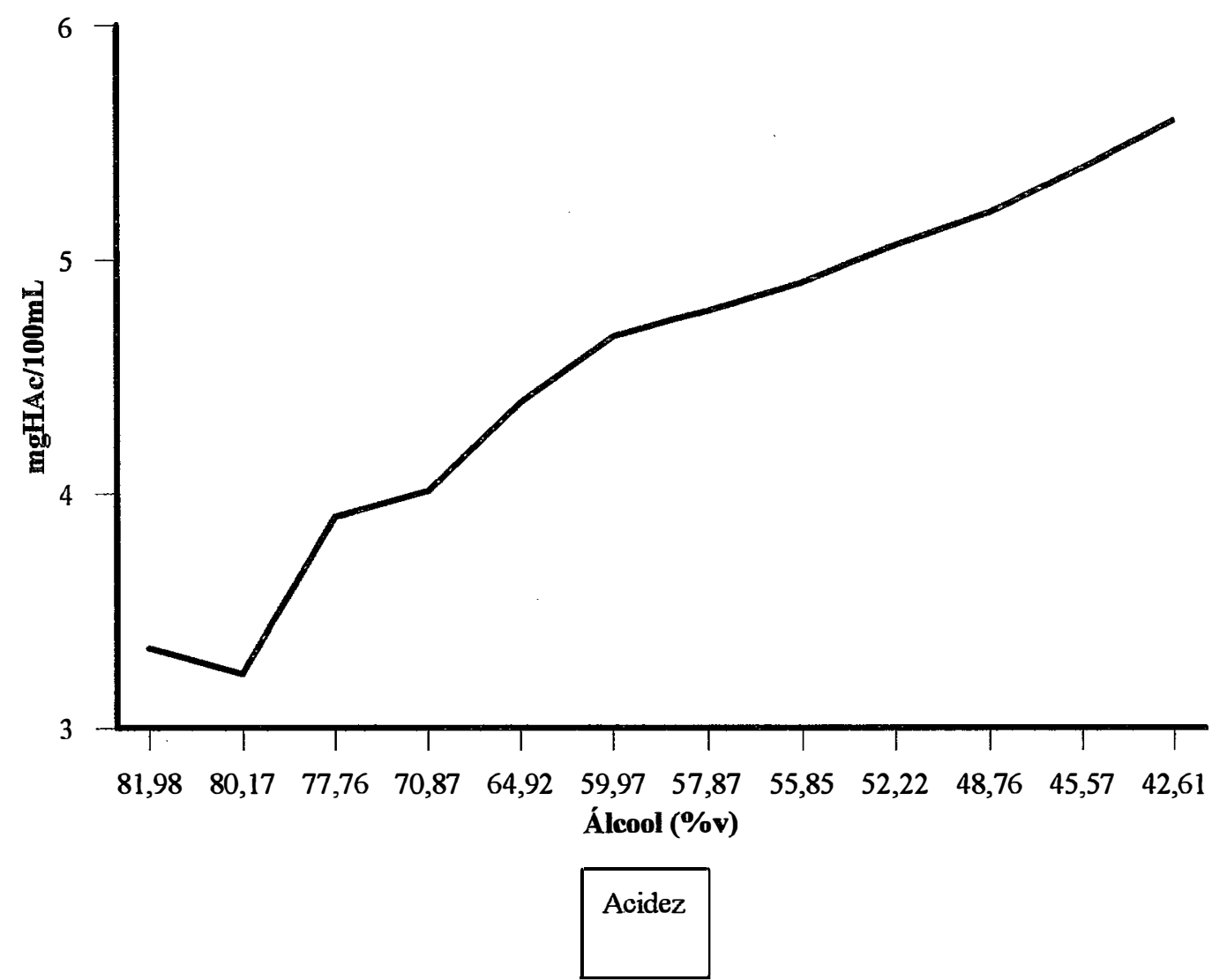

Figura 6 - Variação da concentração de acidez em função da concentração de álcool (\%v) no destilado. Primeira destilação. 


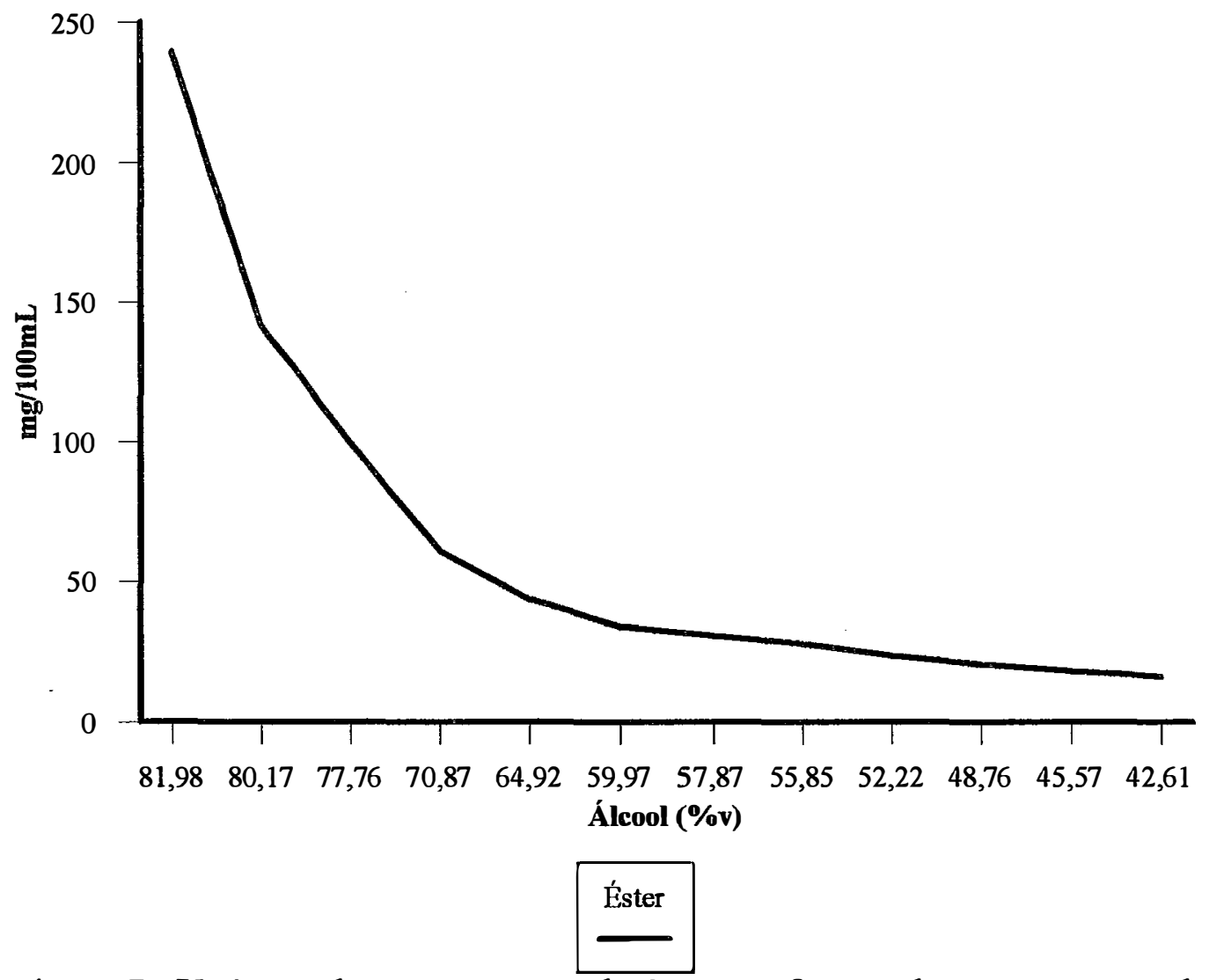

Figura 7 - Variação da concentração de éster em função da concentração de álcool (\%v) no destilado. Primeira destilação. 


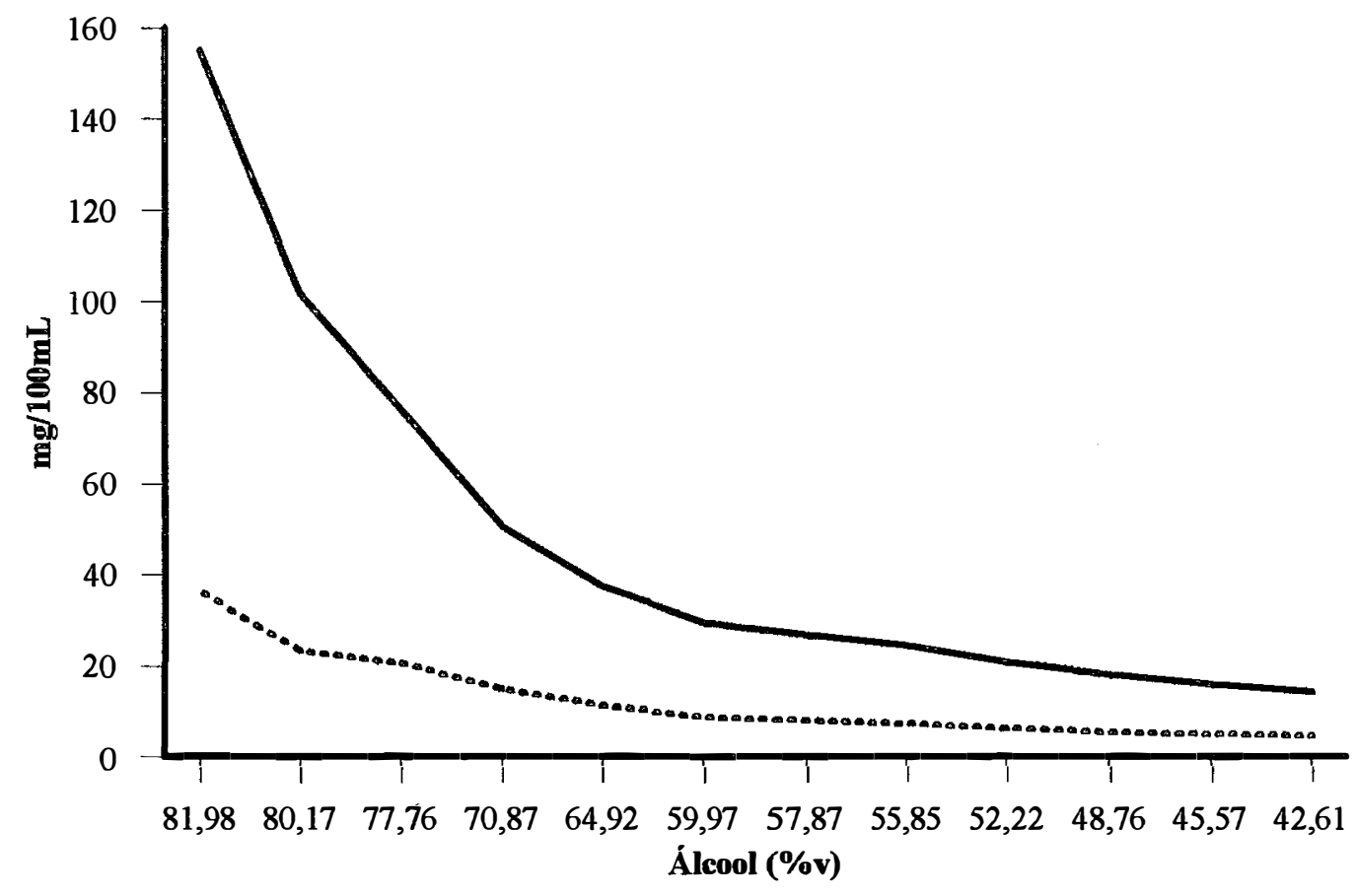

Aldeído Acético Metanol

Figura 8 - Variação da concentração de aldeído acético e de metanol em função da concentração de álcool (\%v) no destilado.

Primeira destilação. 


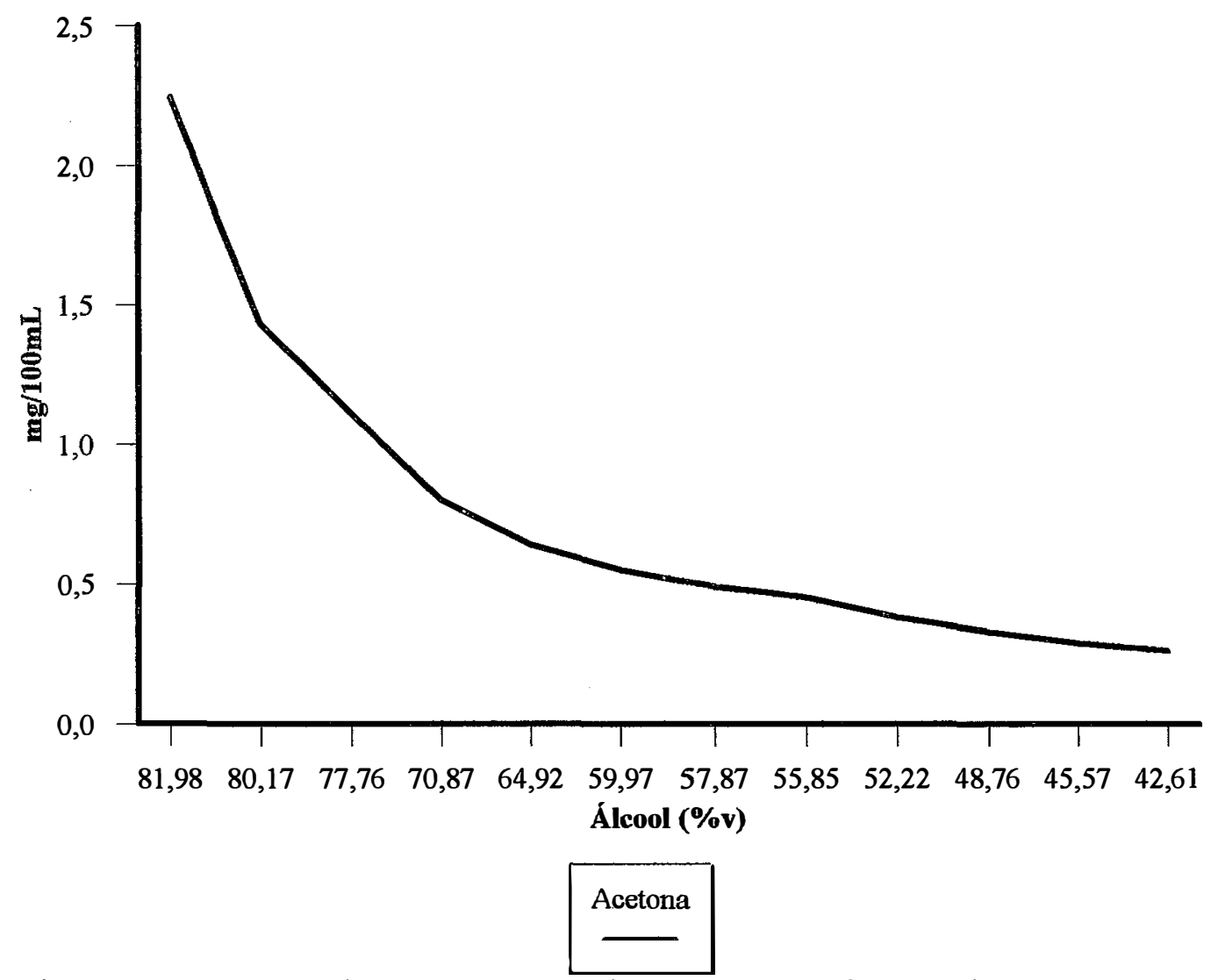

Figura 9 - Variação da concentração de acetona em função da concentração de álcool (\%v) no destilado. Primeira destilação. 


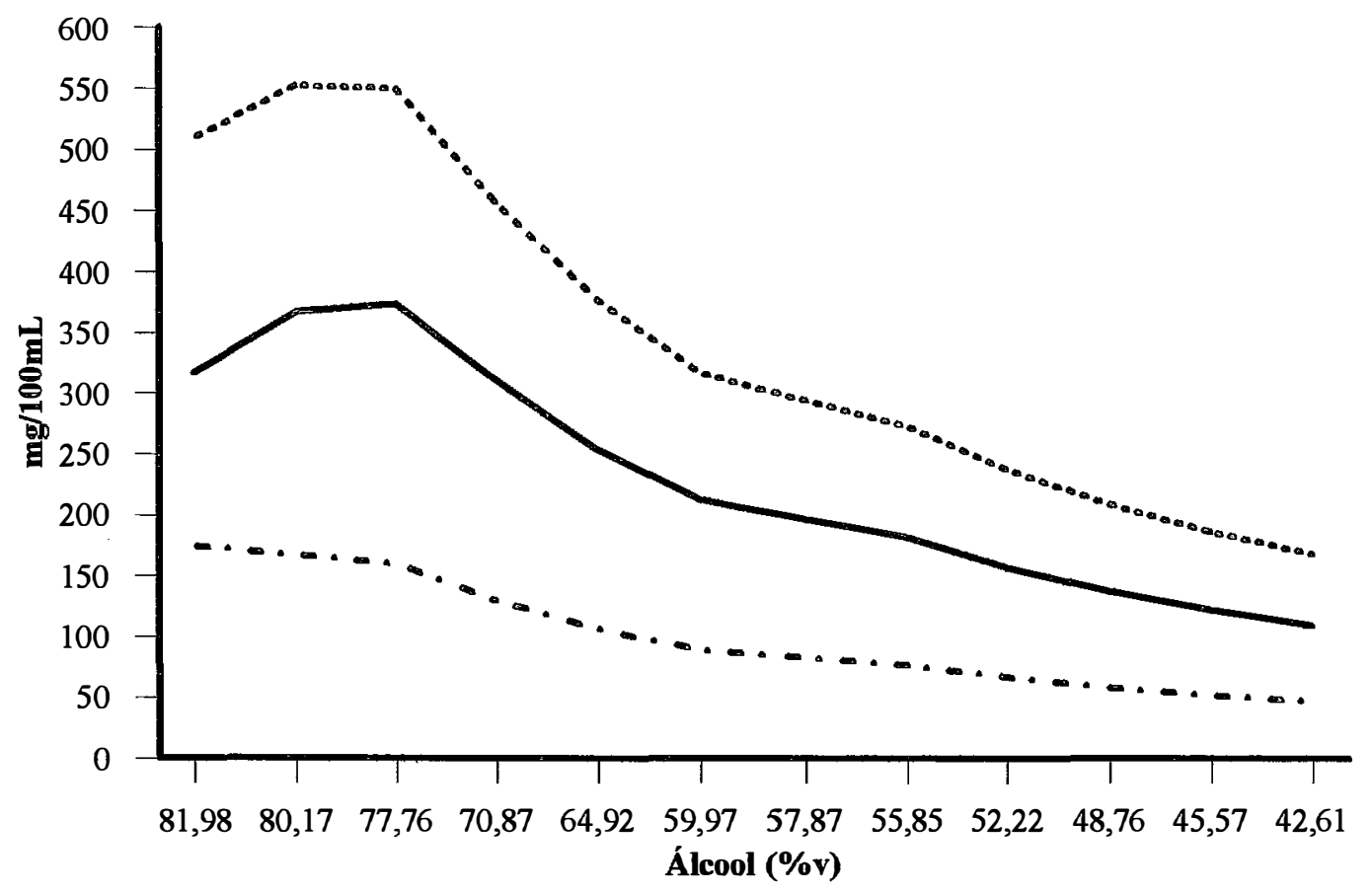

I-Amílico Alcoóis Superiores I-Butanol

anase - - -

Figura 10 - Variação da concentração de i-amílico, i-butanol e de alcoóis superiores em função da concentração de etanol (\%v) no destilado. Primeira destilação. 


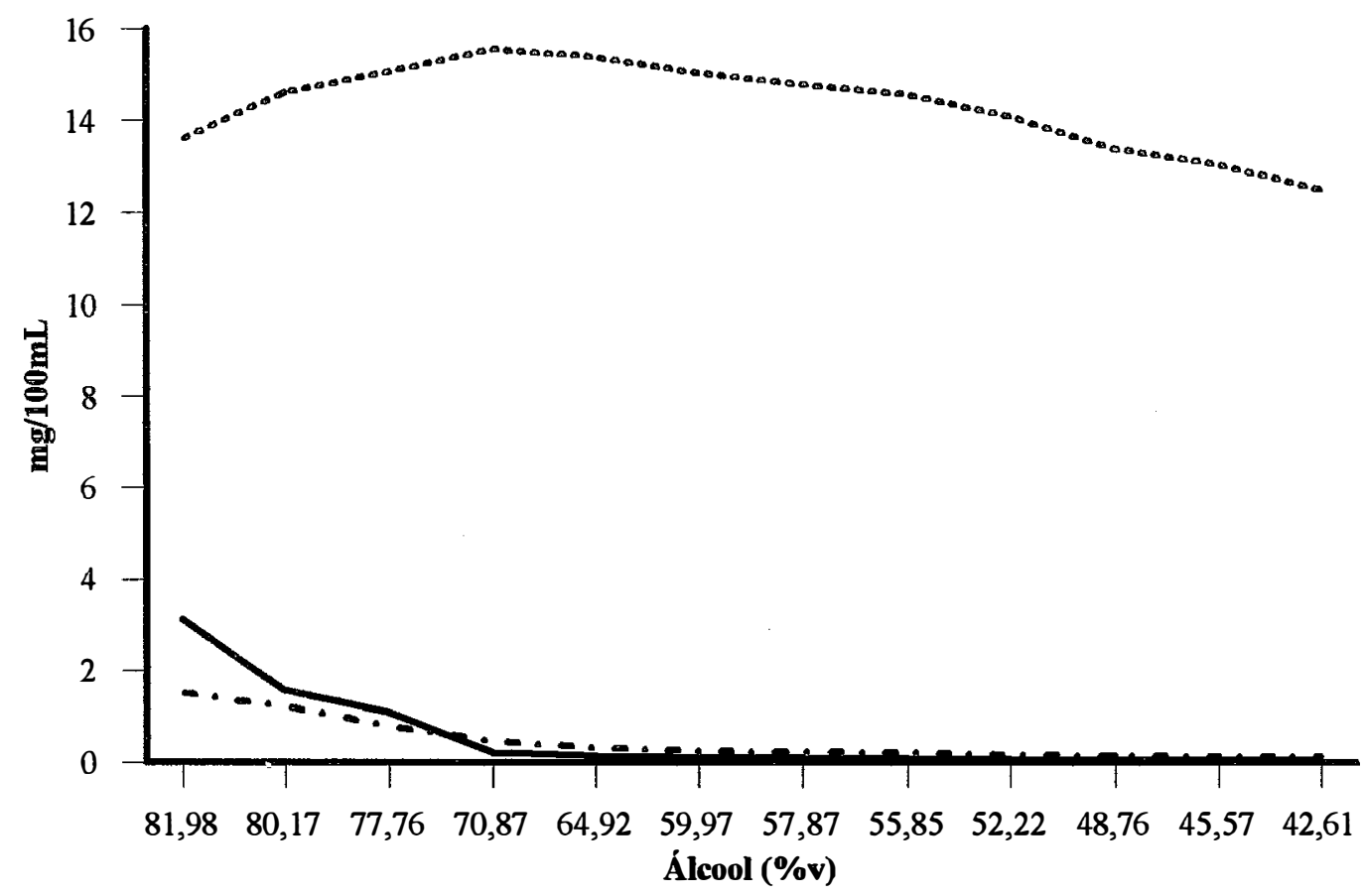

N-Propanol N-Butanol N-Amílico acase. - -.

Figura 11 - Variação da concentração de n-propanol, n-butanol e de n-amílico em função da concentração de etanol (\%v) no destilado. Primeira destilação. 
Durante a segunda destilação, o comportamento dos congêneres é bastante similar ao da primeira destilação, conforme Figuras 12, 14, 15, 16 e 17, exceto com relação ao teor de acidez que declina durante a destilação (Figura 13). Comparando a composição dos principais compostos voláteis das aguardentes 8 e 9 , verifica-se que, os congêneres no produto varia em função do tipo de fracionamento. A aguardente 9 resultante da remoção da fração cabeça, que destila entre 84,79 a 75,83\% álcool em volume a $20^{\circ} \mathrm{C}$, apresenta menor concentração em álcoois superiores que a aguardente 8, sendo desprovida de congêneres típicos da fração cabeça como aldeído acético, acetona e éster (acetato de etila).

A aguardente 07 , resultante da destilação de mistura hidroalcoólica a 6,25\% de álcool em volume a $20^{\circ} \mathrm{C}$, cujo destilado obtido compreende os compostos que destilam entre 78,55 a $61,84 \%$ de álcool em volume, foi considerada inferior em relação à aguardente-referência.

A aguardente 7 apresentou maior concentração de compostos voláteis em relação às aguardentes 8 e referência. Segundo Unger \& Coffey (1975), à baixa concentração de etanol (10\% em volume ou menos) a volatilidade dos álcoois superiores é maior do que do etanol e esses tendem a se comportar como constituintes de cabeça, podendo ser separados juntamente com aldeídos e ésteres de baixo ponto de ebulição.

Segundo Maia (1994), numa destilação correta o destilado de cabeça deve concentrar a maior parte do metanol proveniente do vinho, num pequeno volume de destilado e deve conter relativamente, pouco etanol. A diluição do destilado obtido durante a primeira destilação com água potável a $6,25 \%$ de álcool em volume, otimizou a diferença de volatilidade entre o etanol e os compostos de maior volatilidade, na segunda destilação, conforme Tabelas 36 e 36(1). A variação da concentração dos congêneres durante o fracionamento da aguardente 7, está representada nas Figuras 18, 19, 20, 21, 22, 23 e 24. 


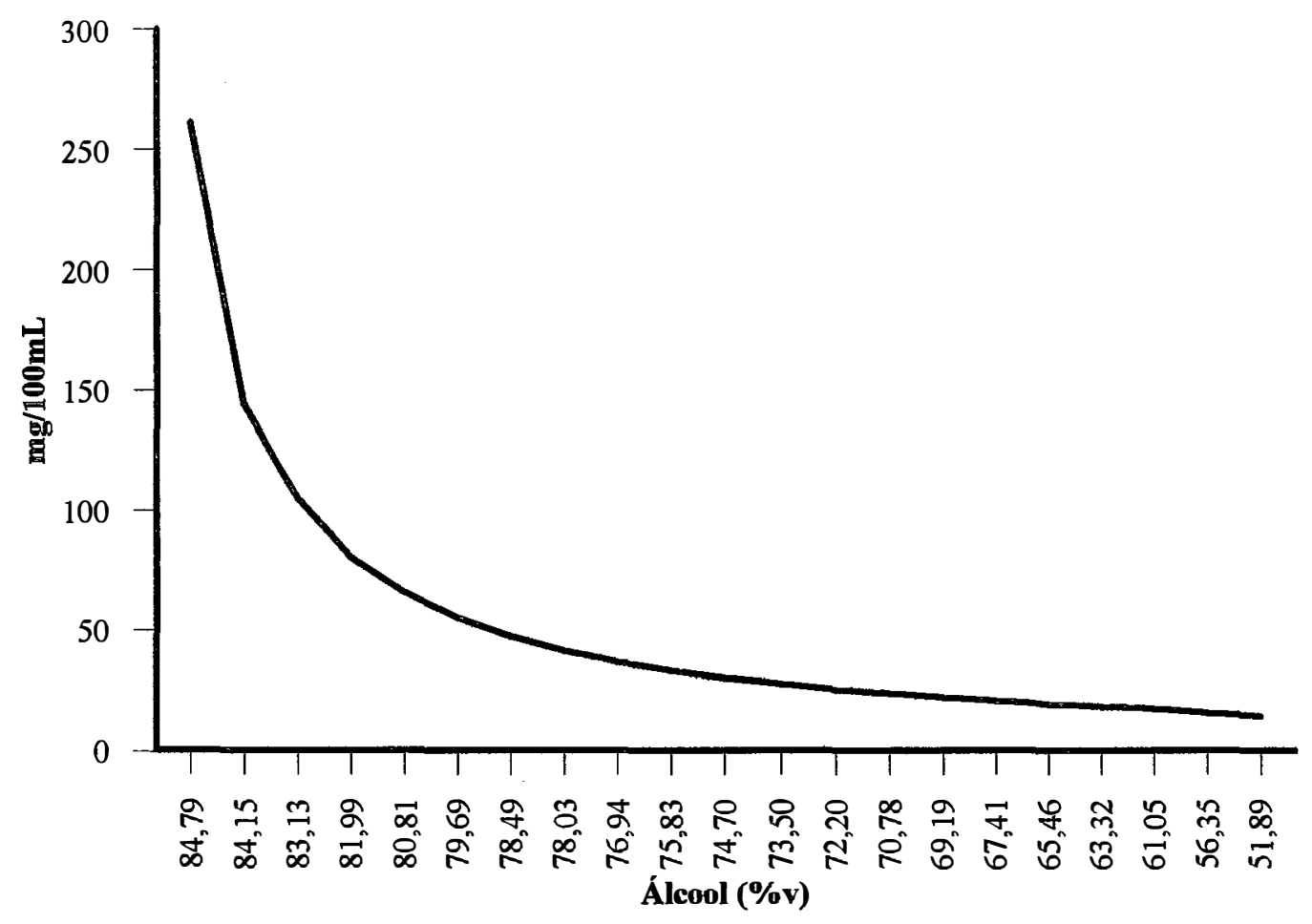

Éster

Figura 12 - Variação da concentração de éster em função da concentração de de etanol (\%v) no destilado. Segunda destilação. 


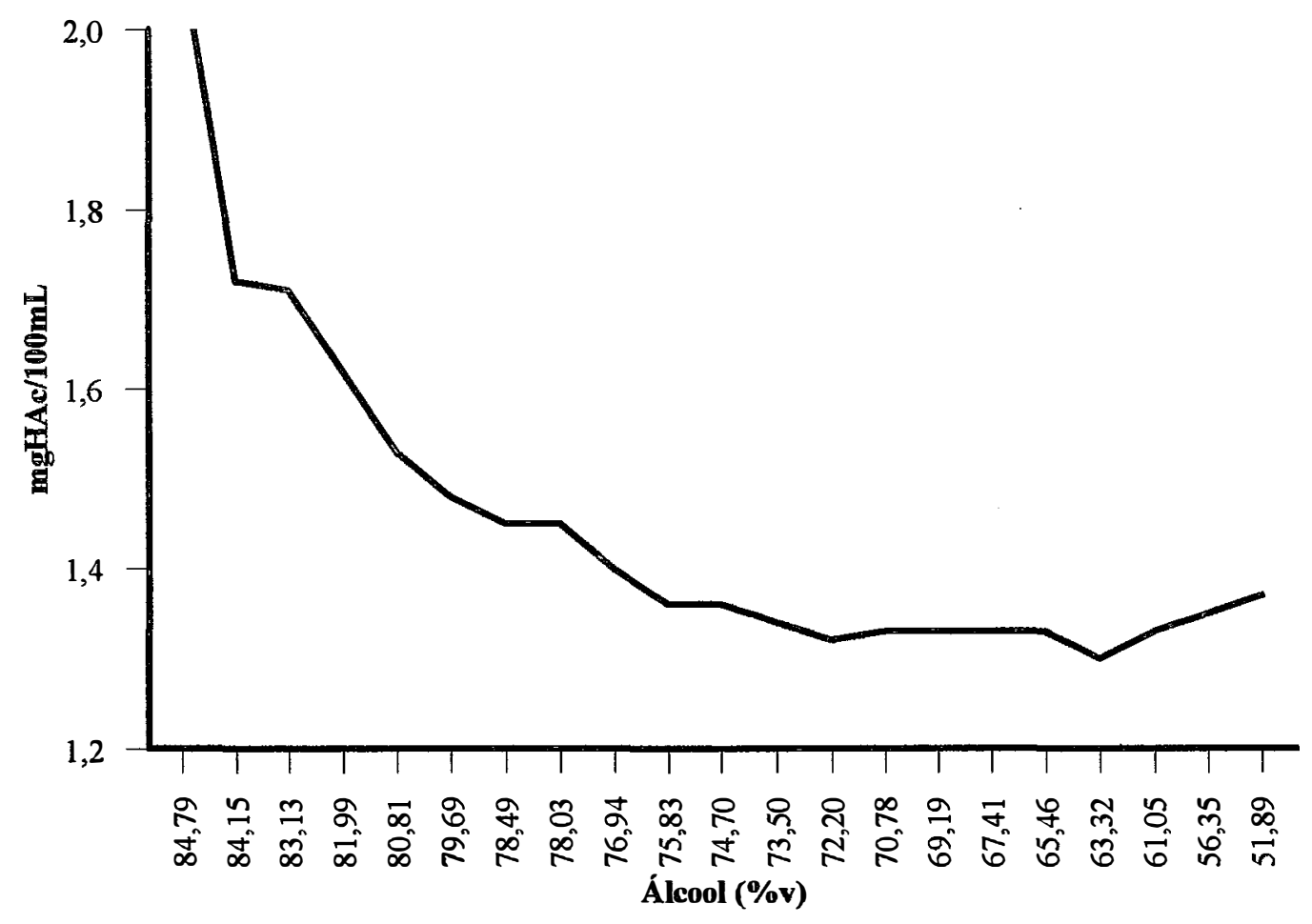

Acidez

Figura 13 - Variação da concentração de acidez em função da concentração de de álcool (\%v) no destilado. Segunda destilação. 


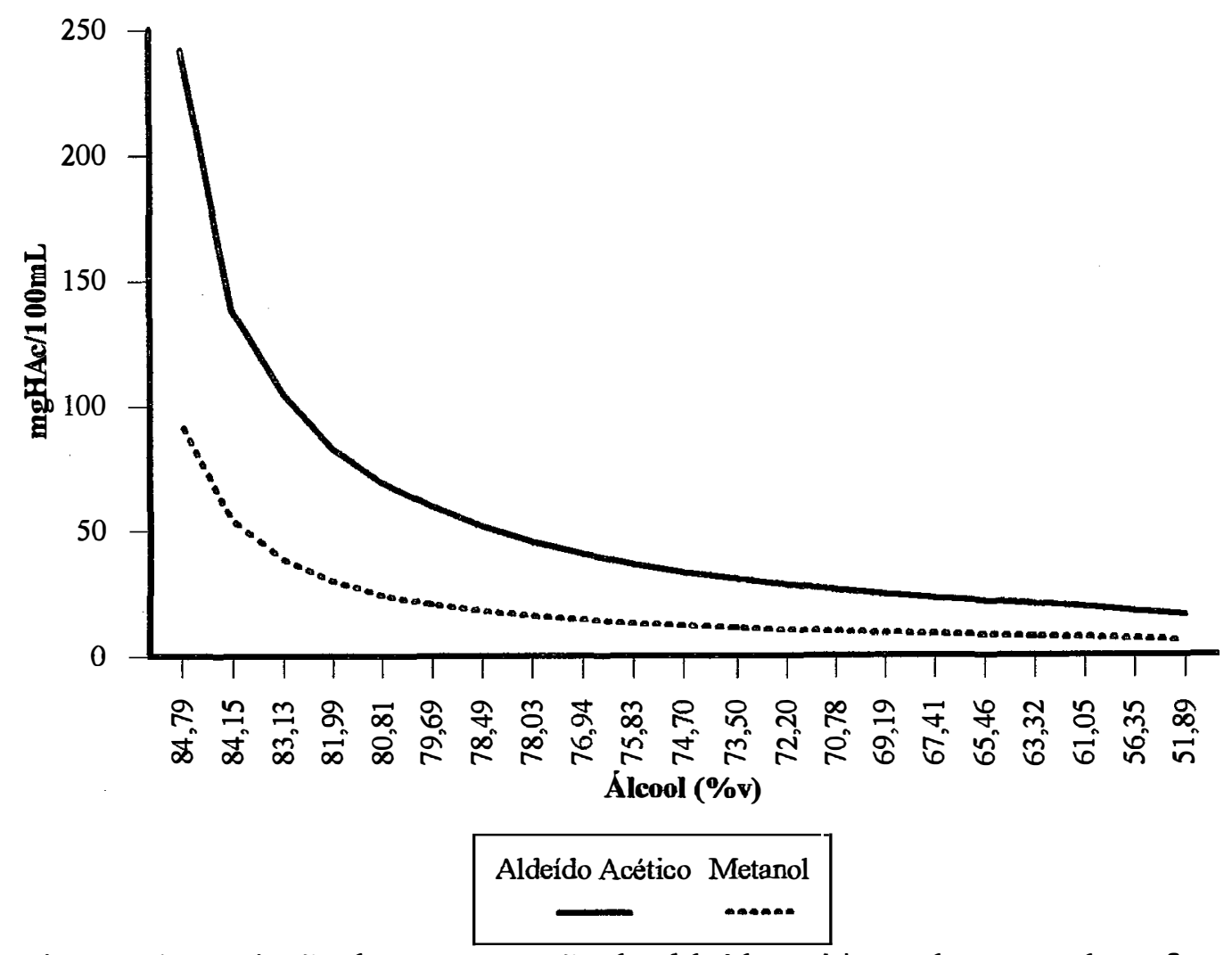

Figura 14 - Variação da concentração de aldeído acético e de metanol em função da concentração de álcool (\%v) no destilado. Segunda destilação. 


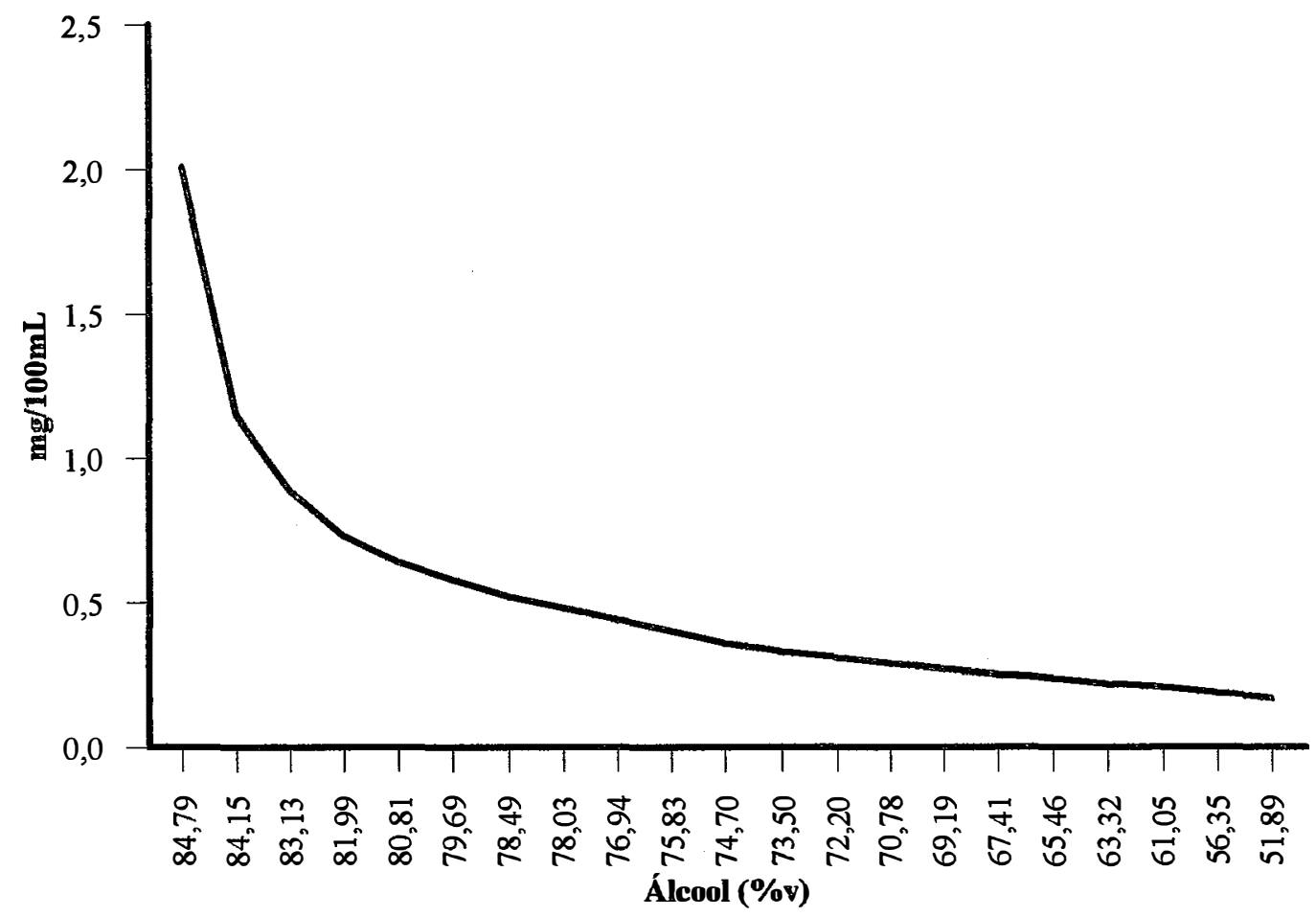

Acetona

Figura 15 - Variação da concentração de acetona em função da concentração de álcool (\%v) no destilado. Segunda destilação. 


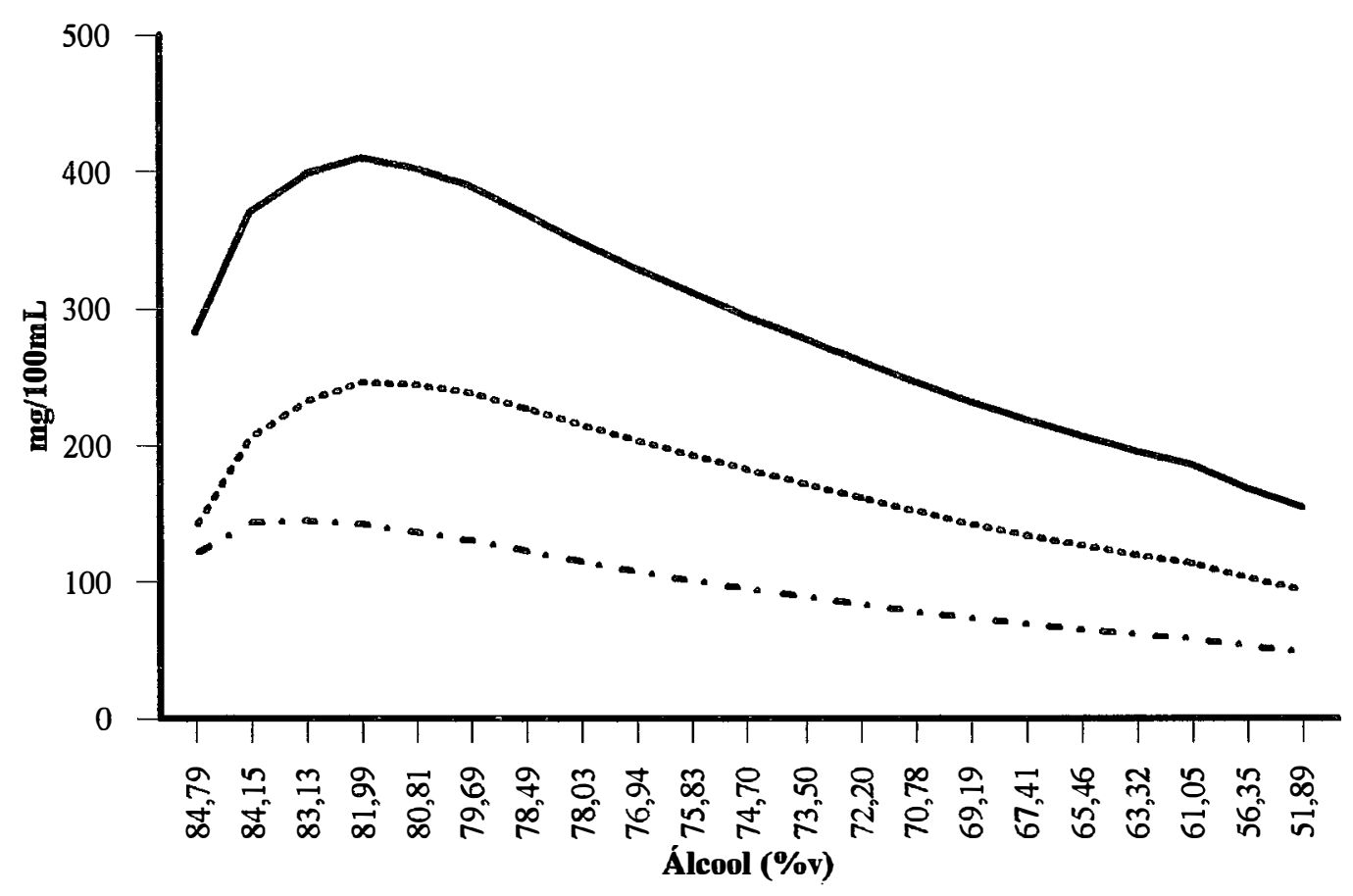

I-Amílico Alcoóis Superiores I-Butanol

a..... - - -

Figura 16 - Variação da concentração de i-amílico, i-butanol e de alcoóis superiores em função da concentração de álcool (\%v) no destilado. Segunda destilação. 


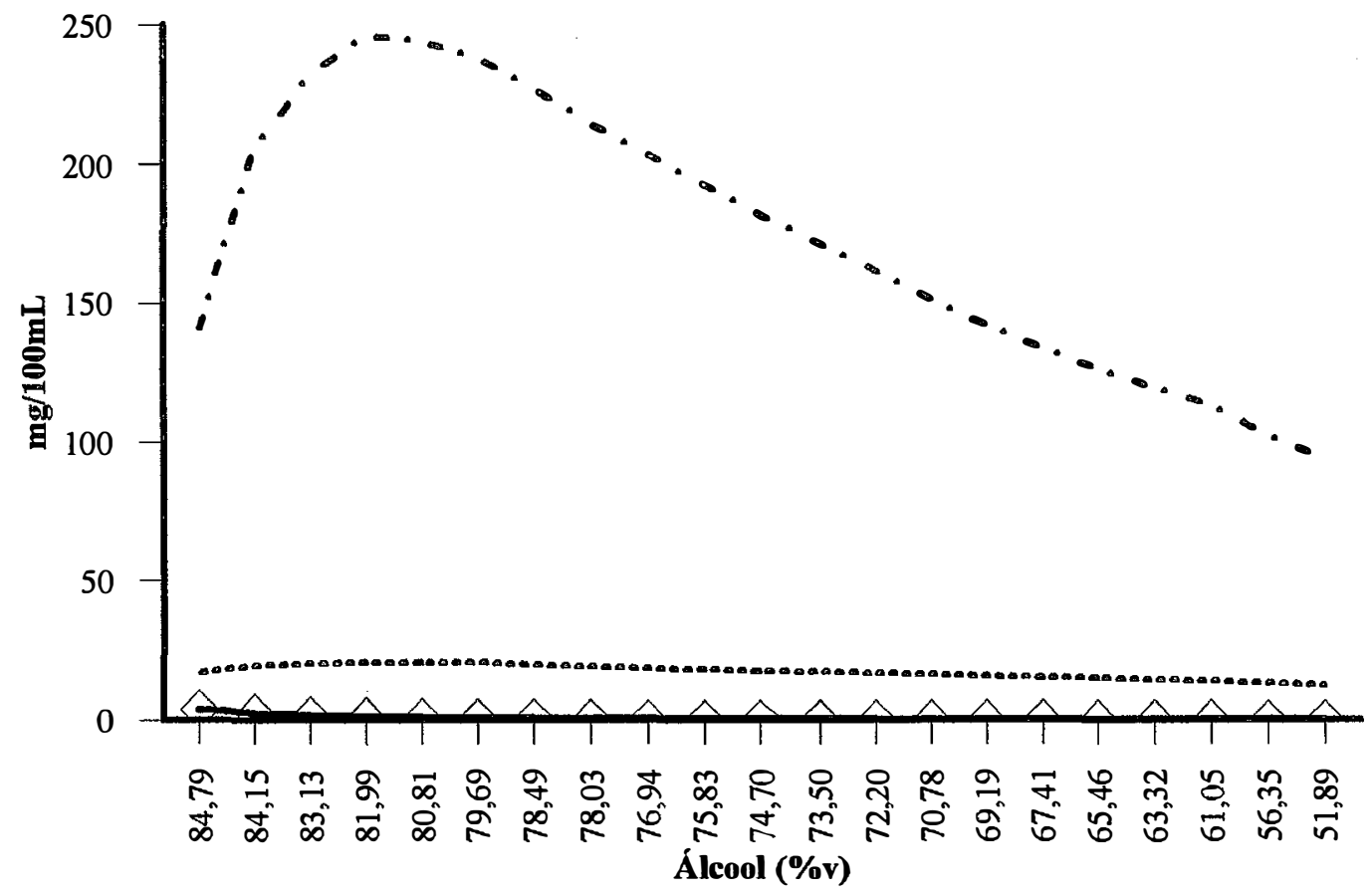

N-Propanol N-Butanol N-Amílico

Figura 17 - Variação da concentração de n-propanol, n-butanol e de n-amílico em função da concentração de álcool (\%v) no destilado.

Segunda destilação. 


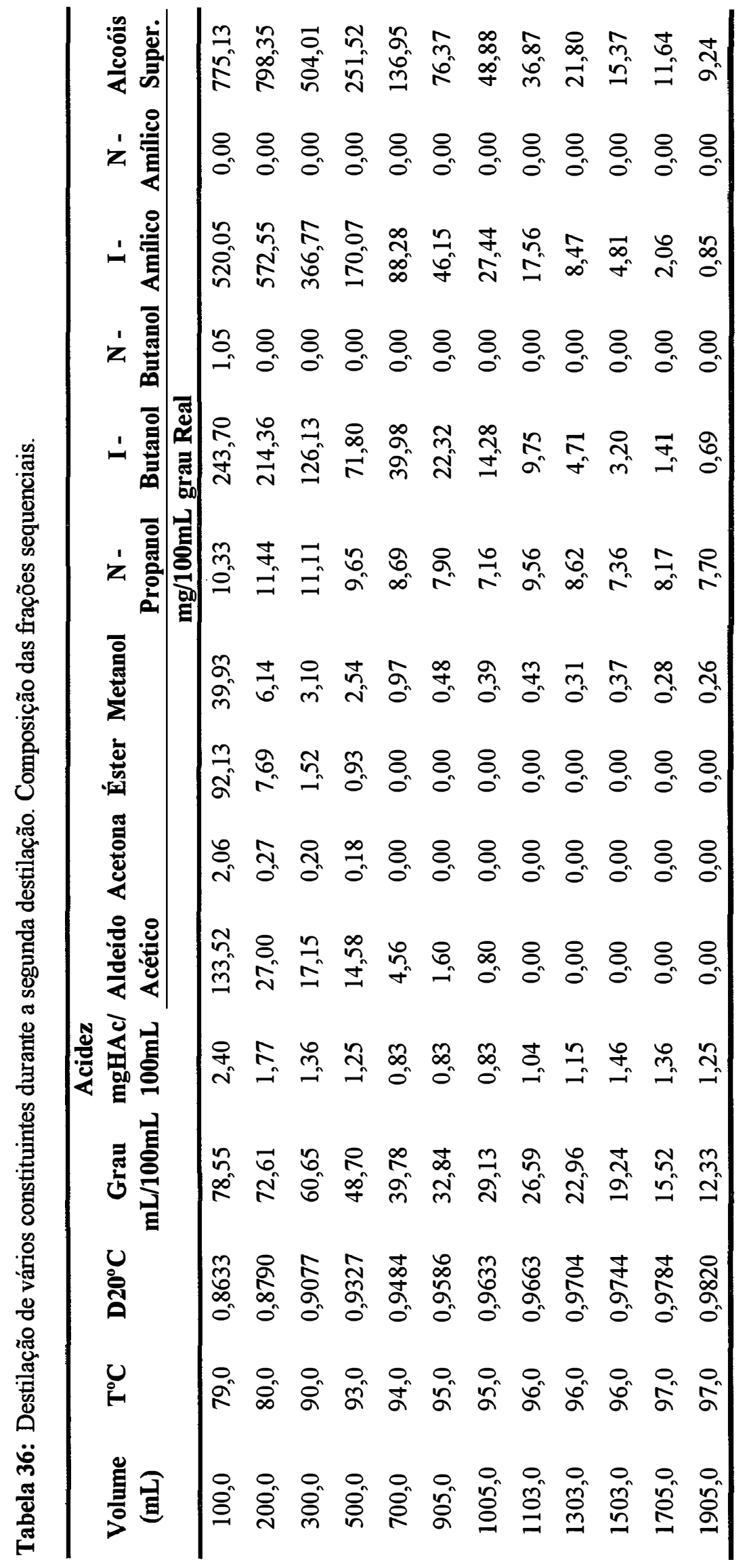




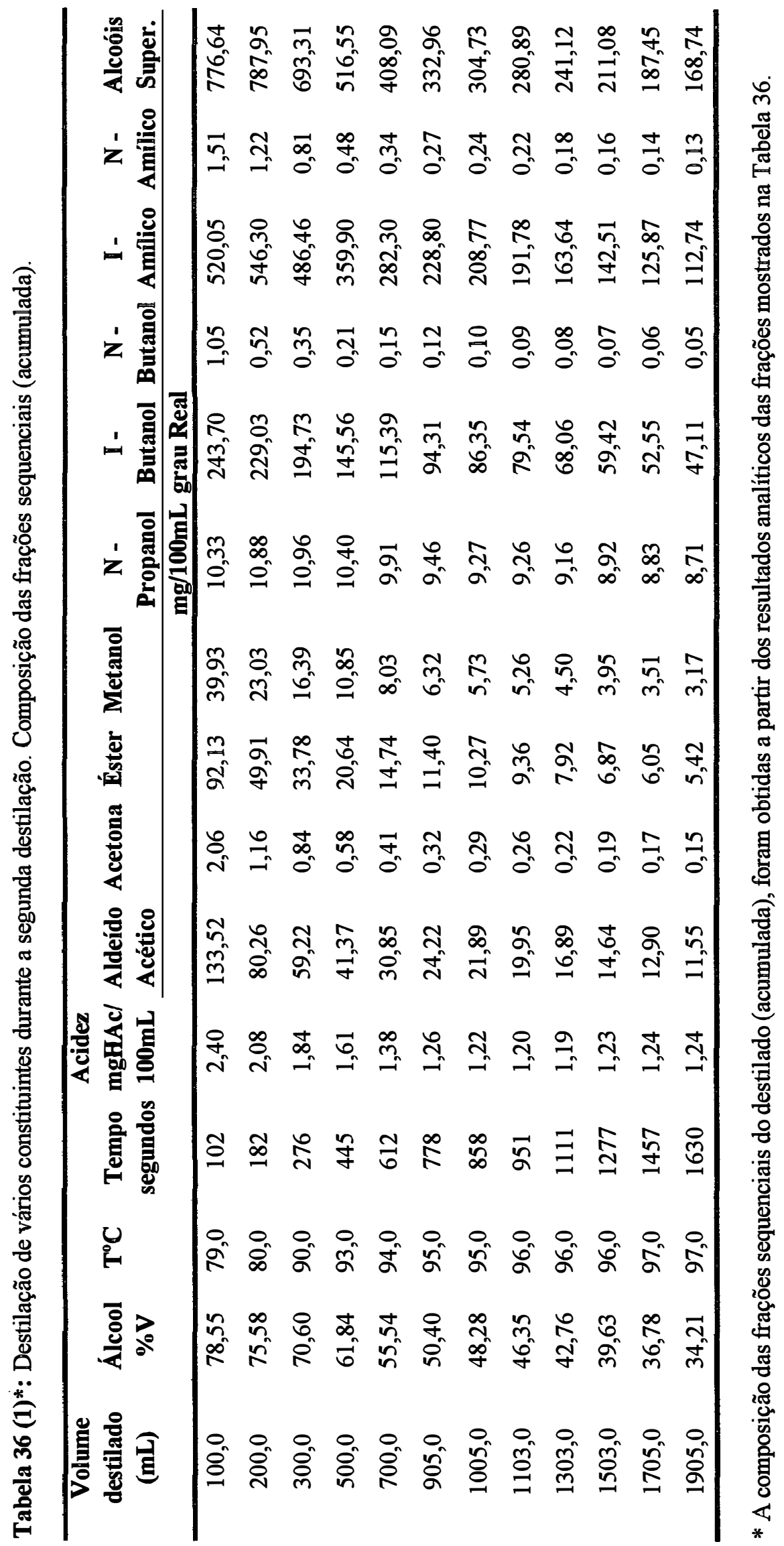




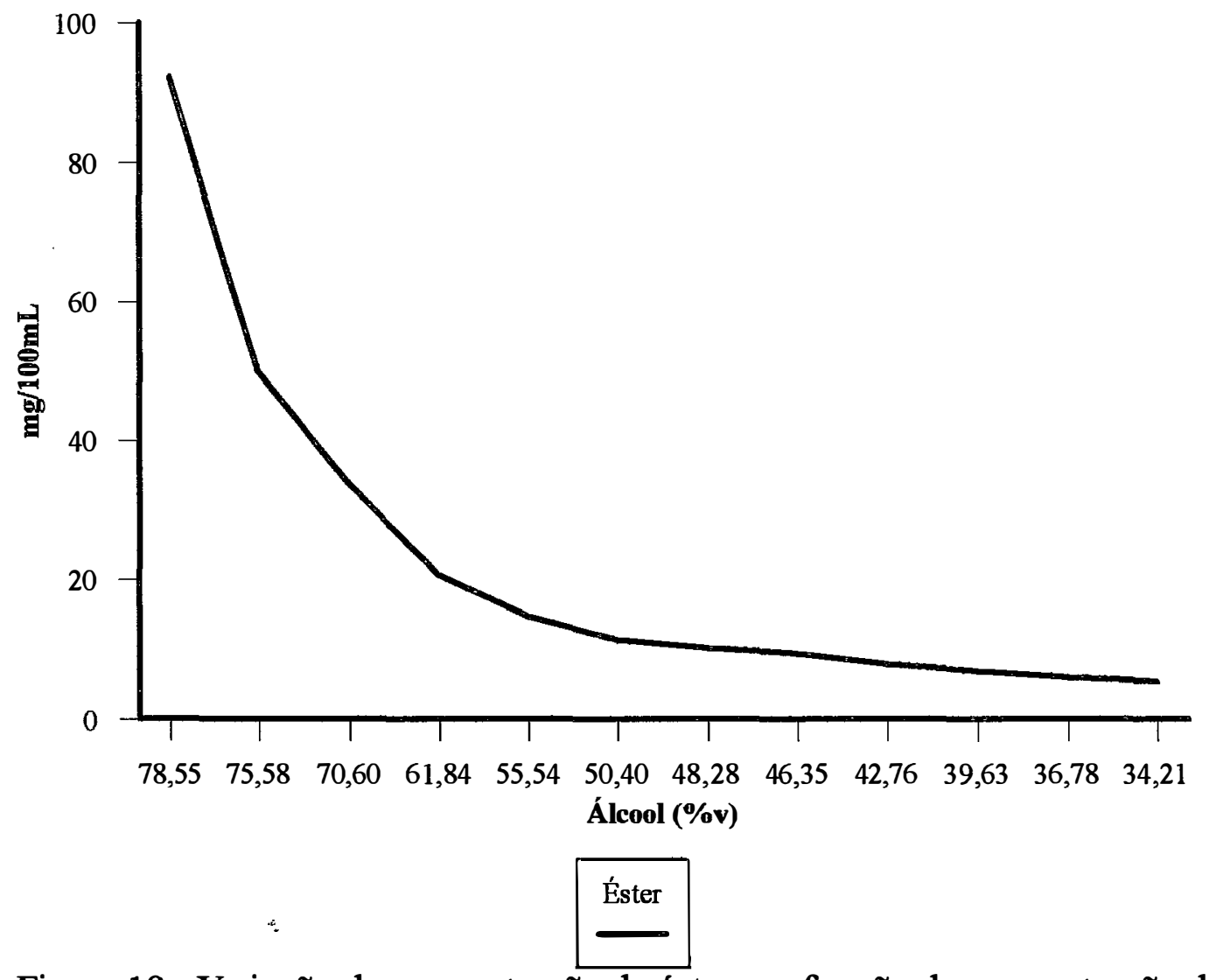

Figura 18 - Variação da concentração de éster em função da concentração de de álcool (\%v) no destilado. Segunda destilação. 


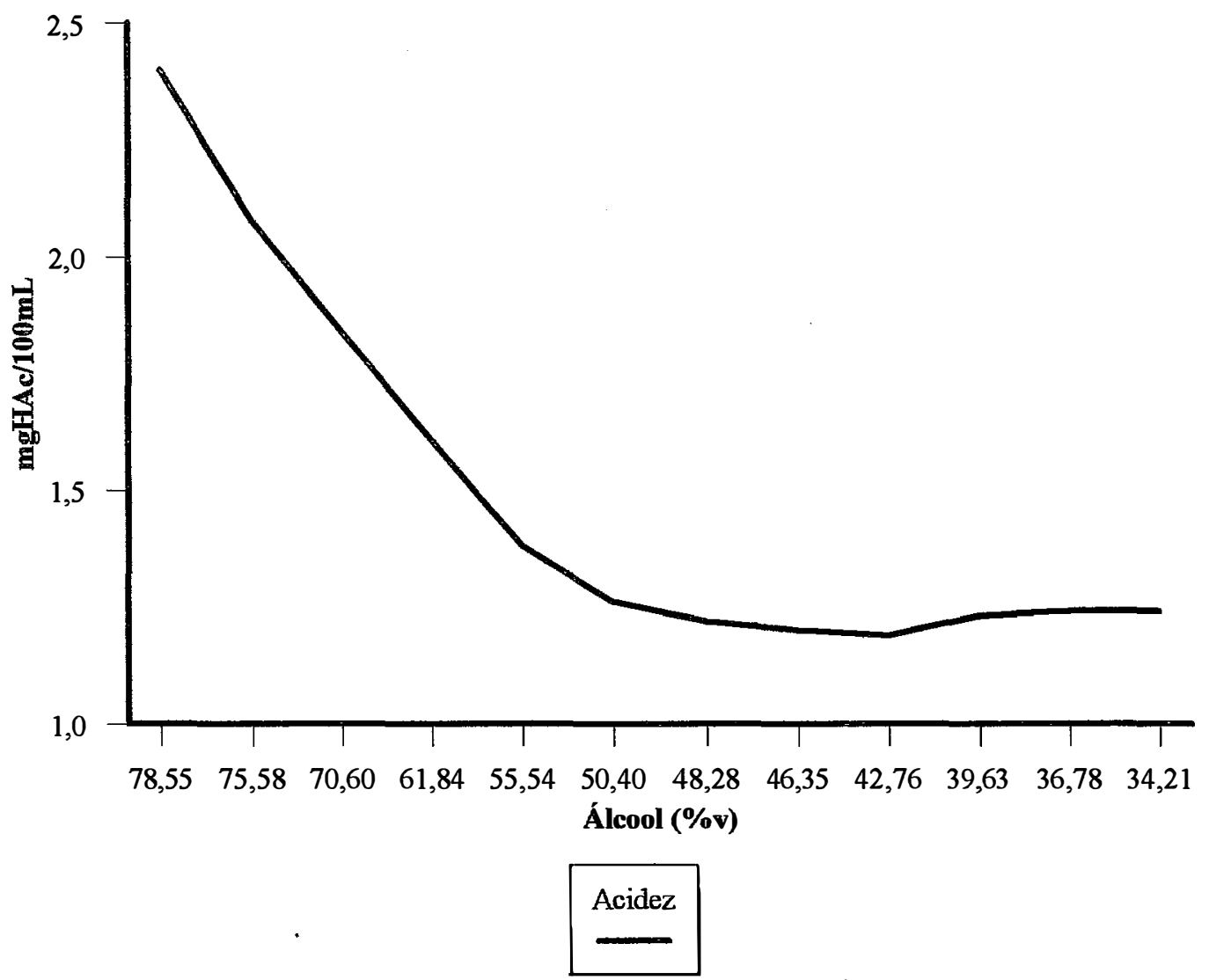

Figura 19 - Variação da concentração de acidez em função da concentração de de álcool (\%v) no destilado. Segunda destilação. 


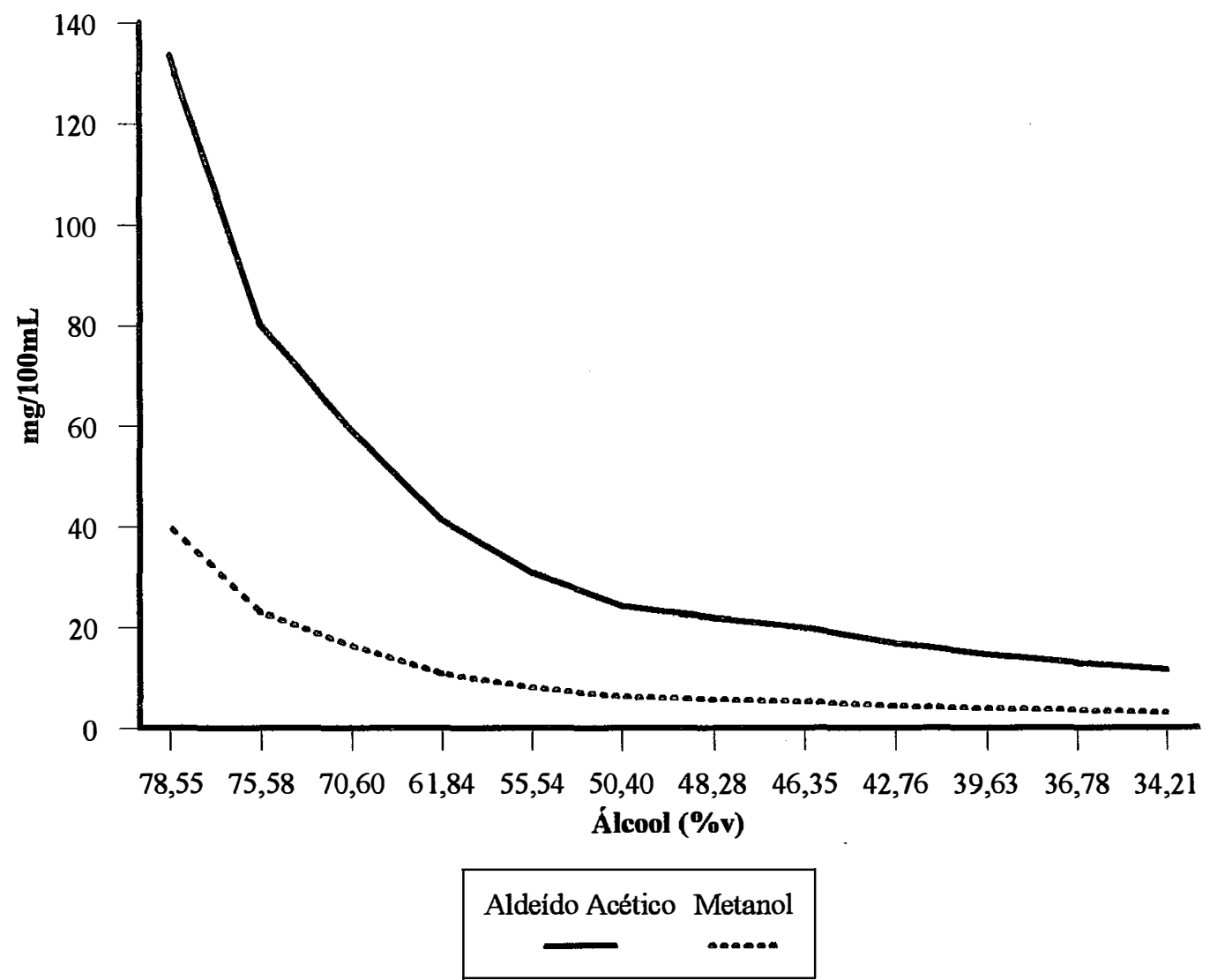

Figura 20 - Variação da concentração de aldeído acético e de metanol em função concentração de álcool (\%v) no destilado. Segunda destilação 


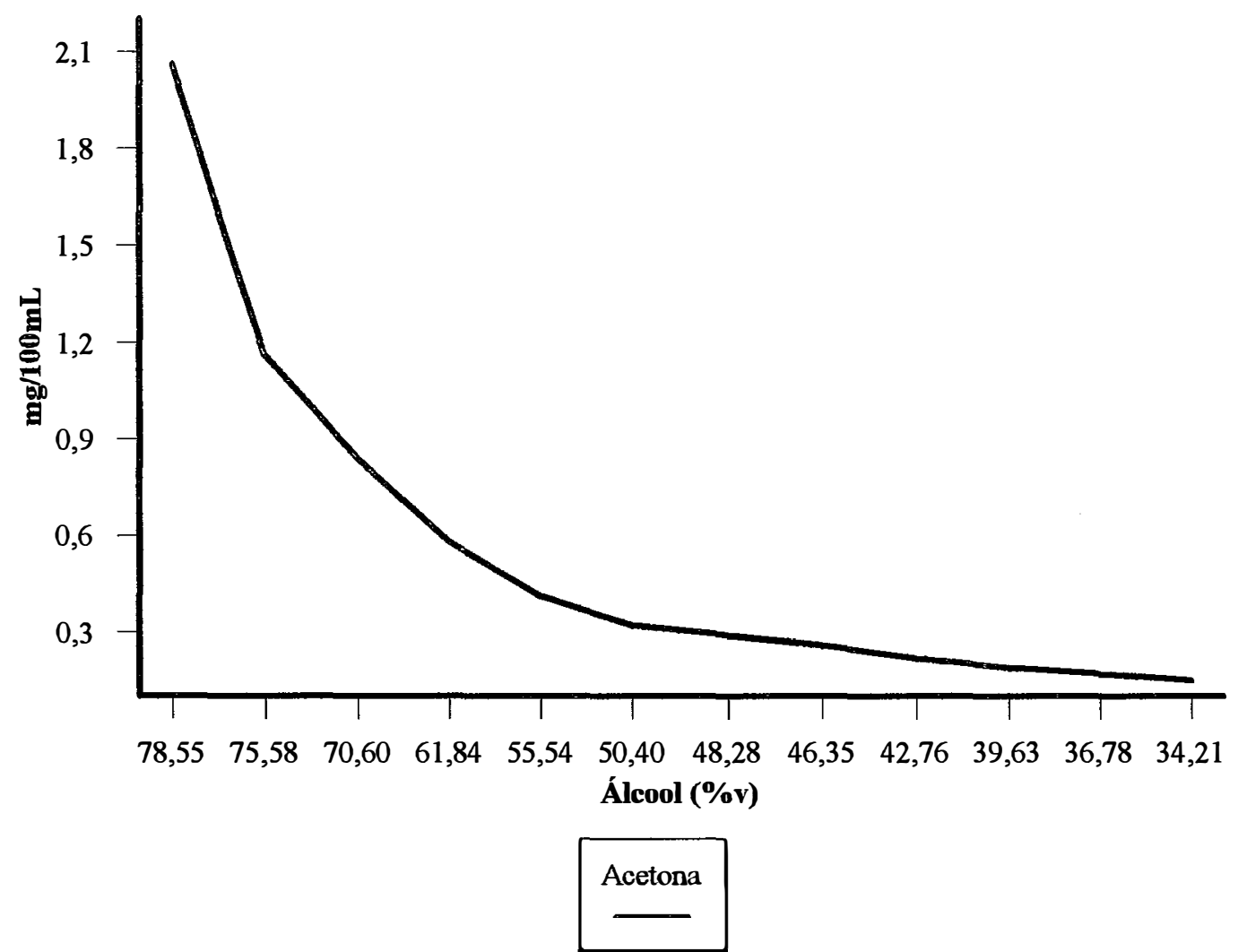

Figura 21 - Variação da concentração de acetona em função da concentração da concentração de álcool (\%v) no destilado. Segunda destilação. 


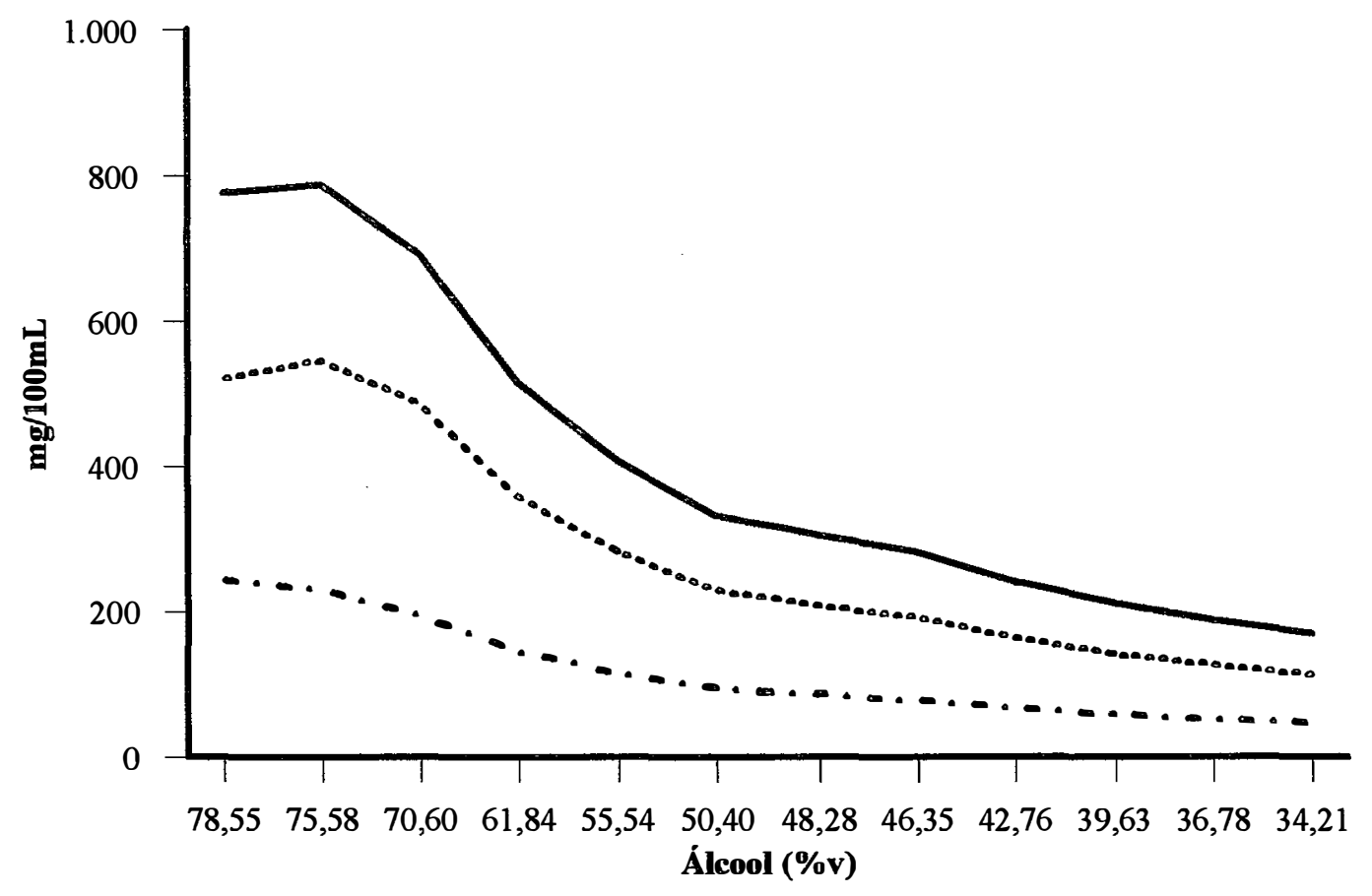

I-Amílico Alcoóis Superiores I-Butanol

Figura 22 - Variação da concentração de i-amílico, i-butanol e de alcoóis superiores em função da concentração de etanol (\%v) no destilado. Segunda destilação. 


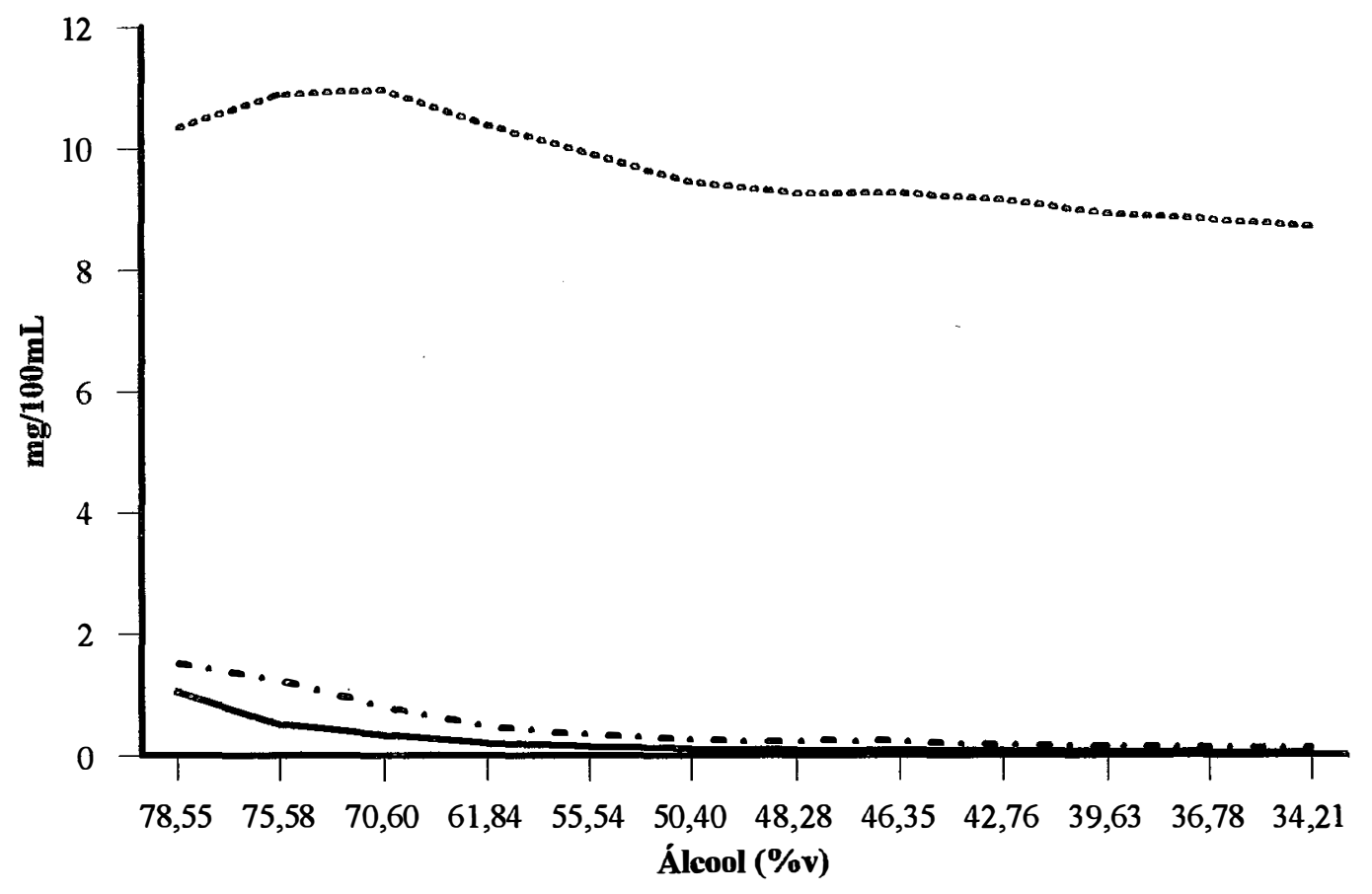

N-Propanol N-Butanol N-Amílico

Figura 23 - Variação da concentração de n-propanol, n-butanol e de n-amílico em função da concentração de álcool (\%v) no destilado.

Segunda destilação. 


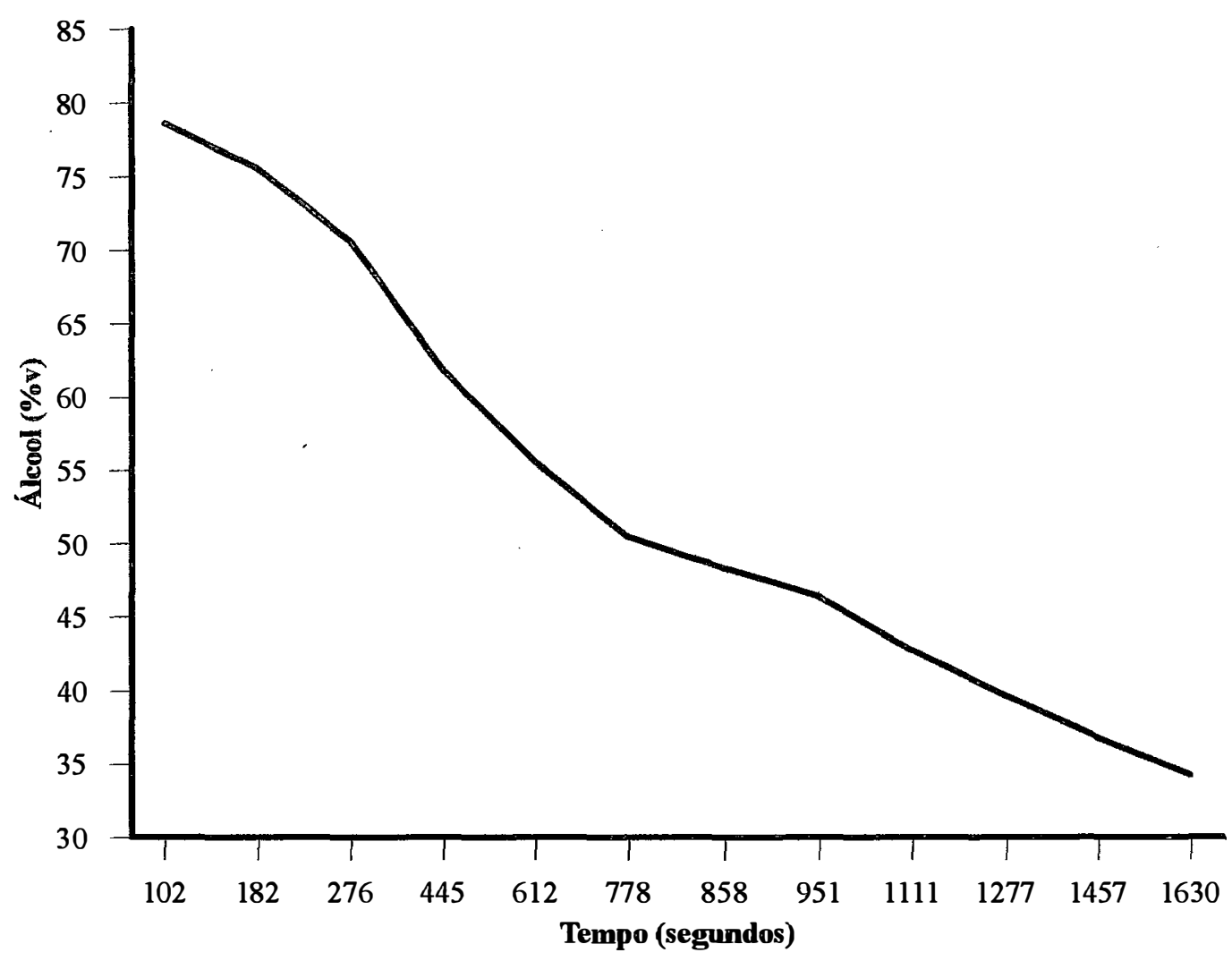

Figura 24 - Variação da concentração de etanol em função do tempo de destilação Segunda destilação. 


\subsection{Comportamento do teor de cobre durante a obtenção de aguardente}

Segundo Lima Neto \& Franco (1994), durante a destilação do vinho, o ataque dos vapores ácidos ao cobre metálico gera o azinhavre $\left[\mathrm{CuOCu}(\mathrm{OH})_{2}\right]$, que é dissolvido durante a operação de destilação, contaminando o produto final com consideráveis concentrações de íons desse elemento. Através de análises químicas da composição das frações seqüenciais do destilado, removidas durante a destilação, cujos resultados podem ser observados nas Tabelas 37 e 38, verificou-se que há relação entre os teores de ácidos e de cobre durante a destilação, sendo que as frações de "cabeça" e de "cauda" apresentaram maior acidez total e teor de cobre.

Segundo Furtado (1995) os valores de acidez total e volátil mostram-se maiores nas frações de cauda, enquanto a acidez fixa é maior na fração cabeça. Moutounet et al. (1992) relatam que os destilados obtidos em coluna contínua apresentam uma maior proporção de produtos de cauda (alta polaridade e ponto de ebulição) cujo destilado é mais rico em ácidos (acidez total e volátil) apresentando menores valores de $\mathrm{pH}$ e maior concentração em sais de cobre, enquanto os destila-dos obtidos em alambiques são mais ricos em produtos de cabeça, apresentando menor acidez e teor em sais de cobre. Através das Figuras 25 e 26, observa-se que no transcorrer da destilação, a variação da concentração de etanol no destilado resulta em alteração quantitativa e qualitativa da composição dos ácidos e concomitantemente na concentração de sais de cobre no destilado. A variação qualitativa da composição dos

ácidos nas frações fundamenta-se nas propriedades físicas desses, ou seja, nas características de destilação uma vez que não foram identificados. 
Lima Neto \& Franco (1994), analisaram 73 amostras de aguardente, coletadas pelo País e verificaram a presença de até $14 \mathrm{mg} \mathrm{L}^{-1}$ de cobre, cujo valor médio foi de $4,2 \mathrm{mg} \mathrm{L}^{-1}$. A presença de cobre é intrínseca à produção de aguardente de boa qualidade, pois devido sua ação catalítica nos processos de oxidação, esse elemento tem uma significante função na formação do flavor da bebida. Tanner (1969) recomenda para minimizar a contaminação por cobre, que os equipamentos de destilação possuam as partes ascendentes construídas em cobre e as partes descendentes (seção de resfriamento) em aço inoxidável; dessa forma, previne a formação de sais de cobre derivado de ácido acético, os quais durante a estocagem podem reagir com ácidos orgânicos, resultando produtos de coloração verde.

Nóbrega \& Silva (1994) relatam a avaliação quantitativa de cobre em aguardente de cana de vários segmentos do mercado que não há um padrão bem definido nos produtos disponíveis no mercado e recomendam a ampliação dos trabalhos para uma ampla gama de marcas comerciais e sugerem a reavaliação do padrão recomendado, associando-o com as técnicas de produção de aguardente de cana-deaçúcar. 


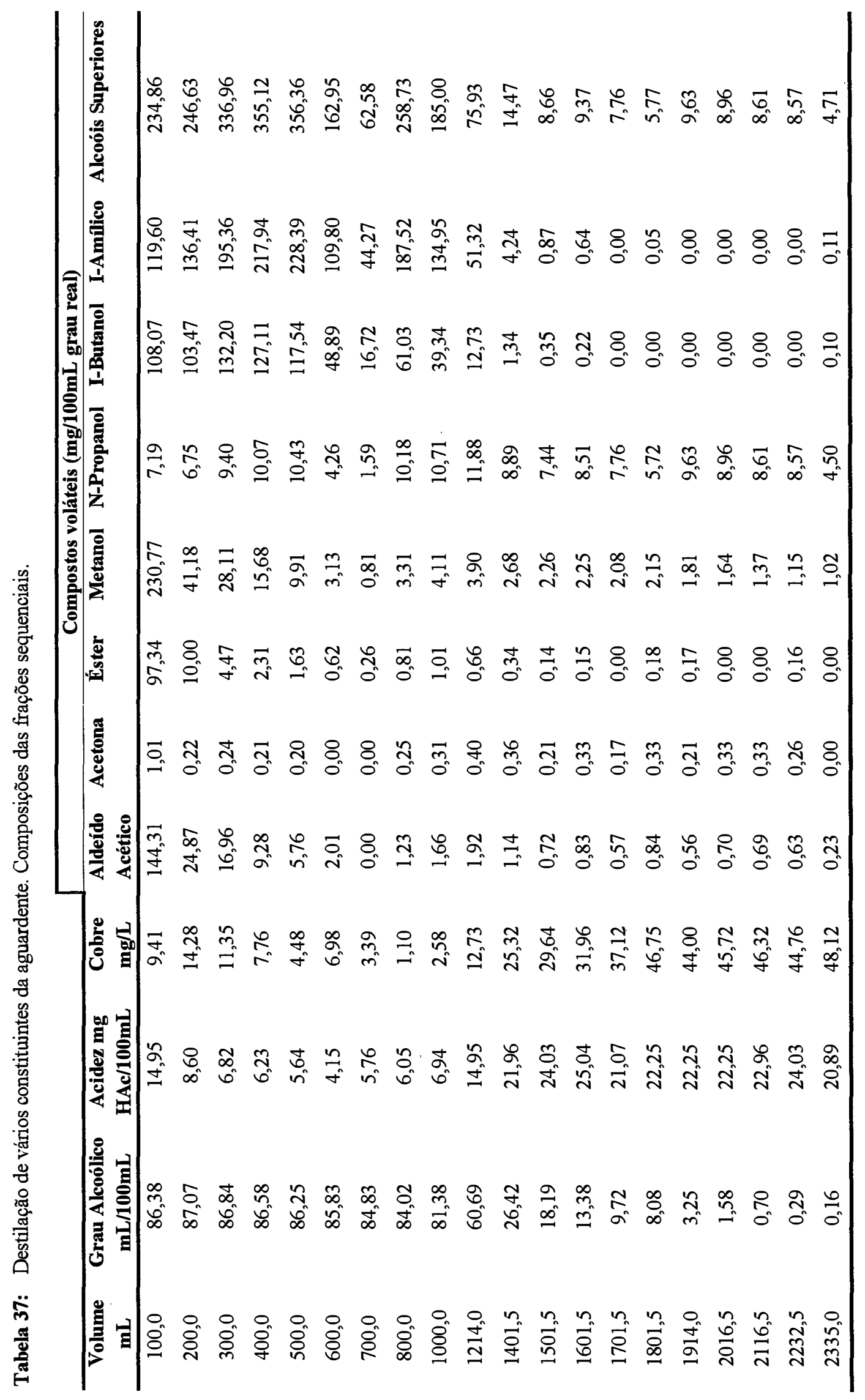


Tabela 38: Composição das frações sequenciais do destilado. Teores acumulados de álcool, ácidos e de cobre.

\begin{tabular}{ccccc}
\hline $\begin{array}{c}\text { Volume } \\
\text { destilado } \\
(\mathbf{m L})\end{array}$ & $\begin{array}{c}\text { Temperatura } \\
\left({ }^{\circ} \mathbf{C}\right)\end{array}$ & $\begin{array}{c}\text { Alcool } \\
(\%)\end{array}$ & $\begin{array}{c}\text { Acidez } \\
\text { mgHAc/100ml }\end{array}$ & $\begin{array}{c}\text { Cobre } \\
\text { mg/L }\end{array}$ \\
\hline 100,0 & 78,5 & 86,38 & 14,95 & 9,41 \\
200,0 & 79,0 & 86,72 & 11,77 & 11,80 \\
300,0 & 79,5 & 86,76 & 10,12 & 11,70 \\
400,0 & 79,5 & 86,72 & 9,15 & 10,70 \\
500,0 & 80,0 & 86,62 & 8,45 & 9,50 \\
600,0 & 80,0 & 86,49 & 7,73 & 9,00 \\
700,0 & 81,0 & 86,25 & 7,45 & 8,20 \\
800,0 & 81,0 & 86,00 & 7,27 & 7,30 \\
1000,0 & 85,0 & 85,10 & 7,21 & 6,40 \\
1214,0 & 96,0 & 80,76 & 8,57 & 7,50 \\
1401,5 & 97,0 & 73,49 & 10,36 & 9,90 \\
1501,5 & 97,0 & 69,81 & 11,27 & 11,20 \\
1601,5 & 97,0 & 66,28 & 12,13 & 12,50 \\
1701,5 & 97,0 & 62,96 & 12,66 & 13,90 \\
1801,5 & 97,0 & 59,91 & 13,19 & 15,80 \\
1914,0 & 97,0 & 56,58 & 13,72 & 17,40 \\
2016,5 & 97,0 & 53,79 & 14,16 & 18,70 \\
2116,5 & 97,0 & 51,29 & 14,57 & 20,20 \\
2232,5 & 97,0 & 48,64 & 15,06 & 21,40 \\
2335,0 & 97,0 & 46,51 & 15,32 & 22,60 \\
\hline & & & & \\
\hline
\end{tabular}




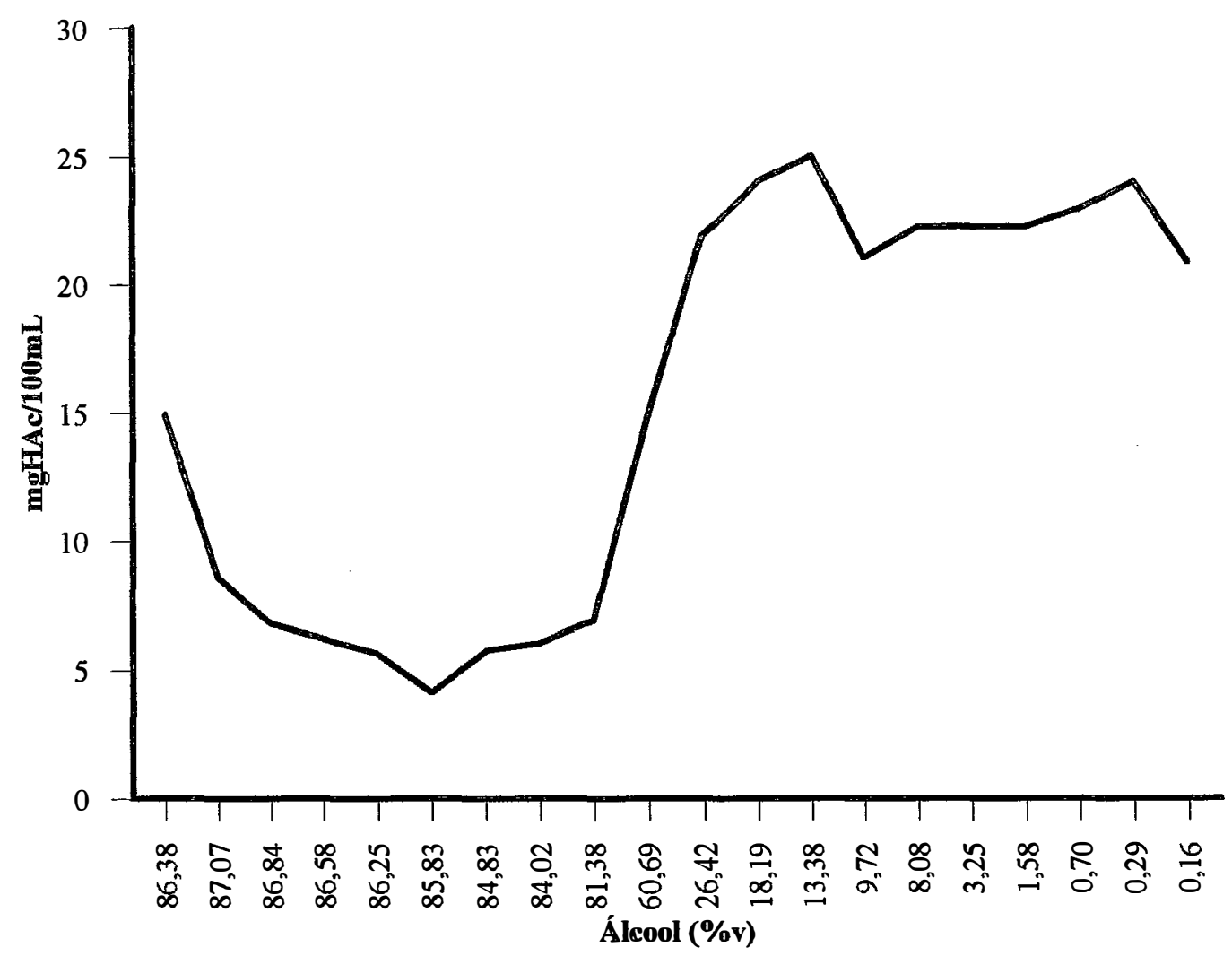

Figura 25 - Variação da acidez total em função da concentração de álcool (\%v) no destilado. 


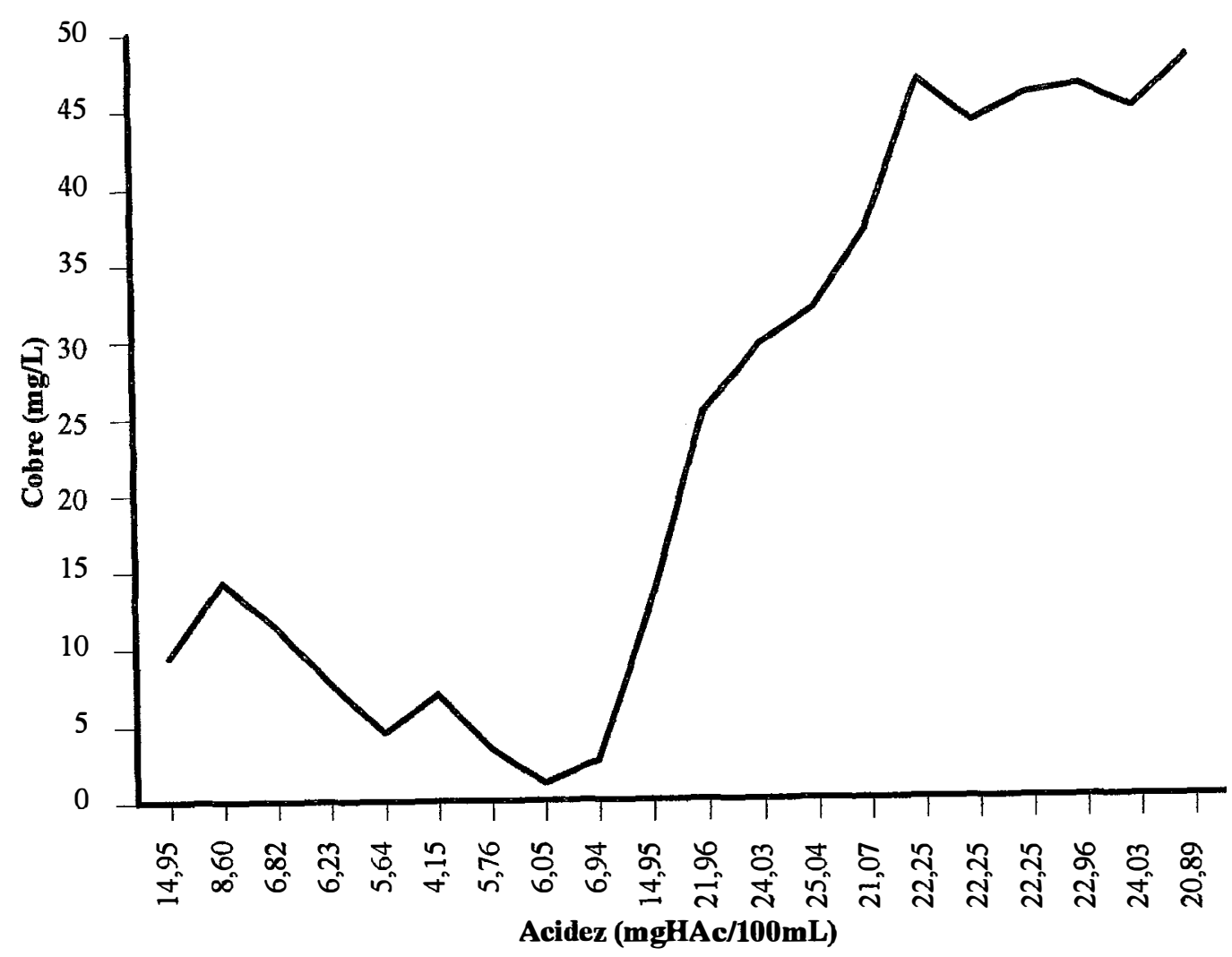

Figura 26 - Variação da concentração de cobre em função da acidez total do destilado. 


\subsection{Análise estatítica}

\subsubsection{Teste $\mathbf{t}$}

Arravés da análise estatística dos resultados obtidos na análise sensorial, através do teste $\mathrm{t}$ (Tabelas 39 e 40), onde foram comparadas as médias das notas auribuídas à cada aguardente com a média 6,0 auribuída à aguardente-referência, pode-se chegar as seguintes ponderações:

- As amostras fracionadas da aguardente 5 (destilado compreende produtos de coração e cauda) apresentaram diferença significativa com relação ao atributo flavor, sendo considerada inferior em relação à aguardente-referência (não fracionada); porém, a aguardente 6 (destilado compreende produtos de cabeça e coração), apesar de apresentar uma média de notas, superior ao da aguardente-referência, não diferiu significativamente desta em decorrência da modificação no flavor da aguardente ser de difícil caracterização. Como pode ser visto na Tabela 40, os valores obtidos de S (desvio padrão da média), para as aguardentes 2 e 5 (livres da fração cabeça) são menores em relação aos obtidos na avaliação sensorial da aguardentes 1 e 6 (livres da fração cauda), ou seja, observou-se um maior nível de concordância entre os provadores da equipe na avaliação das aguardentes 2 e 5 , devido ao menor grau de dificuldade na caracterização e/ou avaliação destas. 
- As aguardentes 8 e 9, bidestiladas, embora obtivessem médias de notas superiores à amostra-referência, 6,31 e 6,12, respectivamente, não diferiram significativamente da mesma. Enquanto a aguardente 7 foi considerada de flavor inferior em relação à aguardente-referência, cuja diferença foi significativa a $1 \%$ de probabilidade.

- A aguardente 12, resultante da destilação de vinho tratado com $\mathrm{Ca}(\mathrm{OH})_{2}$, obteve uma média de notas inferior ao da amostra-referência, apesar de não diferir estatisticamente, constituindo-se em aguardente de difícil caracterização.

- A aguardente 13, resultante da destilação de vinho centrifugado, foi considerada inferior quanto ao flavor em relação ã aguardente-referência, apresentando diferença significativa a $10 \%$ de probabilidade.

- A aguardente 14, proveniente de vinho tratado com $\mathrm{Ca}(\mathrm{OH})_{2}$ e centrifugado, foi considerada estatisticamente inferior, sendo que ocorreu um sinergismo negativo entre os tratamentos sobre o flavor da aguardente.

- A aguardente 15, oriunda de caldo de cana que sofreu tratamento extrativo prévio para remoção de compostos voláteis, obteve uma média de notas superior ao da aguardente-referência, porém, não diferiu estatisticamente da referência. 
- A aguardente 16, resultante da destilação de vinho centrifugado, proveniente de caldo que sofreu tratamento extrativo prévio, foi considerada de qualidade inferior em relação à referência, resultante da ação sinérgica negativa dos dois tratamentos sobre o flavor.

- A aguardente 17, comercial, foi considerada de qualidade inferior quanto ao flavor em relação à amostra-referência.

- A aguardente 18, resultante da destilação de vinhos com teor alcoólico mais elevado, foi considerada superior em relação à aguardente-referência, sendo que a avaliação pela equipe de provadores, foi relativamente fácil em virtude do pequeno valor de s.

$\mathrm{Na}$ avaliação sensorial das aguardentes, cabe salientar as dificuldades na formação da equipe, uma vez que o destilado analisado consiste em um produto bruto, não adoçado e nem envelhecido, operação subsequente à destilação que confere um flavor diferenciado ao padrão de aceitação de flavor das marcas de aguardentes mais populares, que a coloca no segundo time dos destilados (Ribeiro, 1993). A equipe de provadores foi formada tomando por base o poder de discriminação e sua reprodutibilidade e por tratar-se de um teste de preferência, não foi eminente o grau de concordância entre os provadores da equipe. Um aumento do número de provadores na equipe para análise das aguardentes possibilitaria uma melhor avaliação das aguardentes, porém, nosso maior obstáculo foi o interesse dos "candidatos" a provadores, devido às características peculiares do produto. 


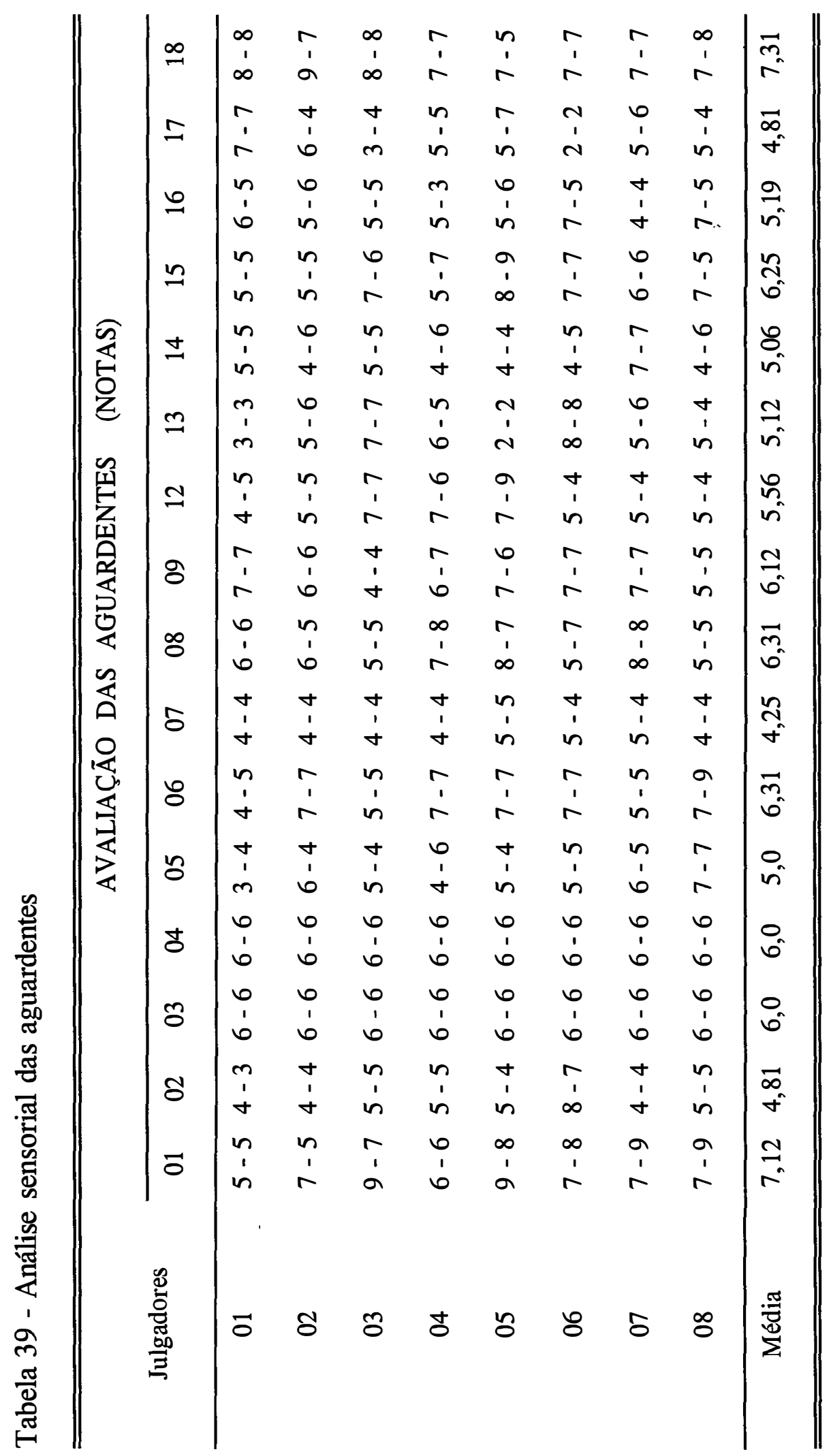


Tabela 40 - Dados estatísticos obtidos pelo teste t

\begin{tabular}{|c|c|c|c|c|c|c|}
\hline Aguardentes & $\mathrm{x}$ & s & $s^{2}$ & $\mathbf{v}(\mathrm{m})$ & $\sqrt{ } \mathrm{v}(\mathrm{m})$ & $\mathrm{t}$ \\
\hline 01 & 7,125 & 1,4549 & 2,1167 & 0,1323 & 0,3637 & $+3,09^{*}$ \\
\hline 02 & 4,8125 & 1,2230 & 1,4958 & 0,0935 & 0,3058 & $-3,88^{*}$ \\
\hline 05 & 5,0 & 1,1547 & 1,3333 & 0,0833 & 0,2887 & $-3,46^{*}$ \\
\hline 06 & 6,3125 & 1,3022 & 1,6958 & 0,1060 & 0,3256 & $+0,96^{\mathrm{ns}}$ \\
\hline 07 & 4,25 & 0,4472 & 0,2000 & 0,0125 & 0,1118 & $-15,65^{*}$ \\
\hline 08 & 6,3125 & 1,25 & 1,5625 & 0,0977 & 0,3125 & $+1,0^{\text {nis }}$ \\
\hline 09 & 6,125 & 1,0878 & 1,1833 & 0,0740 & 0,2720 & $+0,46^{\mathrm{ns}}$ \\
\hline 12 & 5,5625 & 1,4592 & 2,1292 & 0,1331 & 0,3648 & $-1,20^{\mathrm{ns}}$ \\
\hline 13 & 5,1250 & 1,9279 & 3,7168 & 0,2323 & 0,4820 & $-1,81^{* *}$ \\
\hline 14 & 5,0625 & 1,0626 & 1,1291 & 0,0706 & 0,2656 & $-3,53^{*}$ \\
\hline 15 & 6,25 & 1,2383 & 1,5334 & 0,0958 & 0,3096 & $+0,81^{\mathrm{ns}}$ \\
\hline 16 & 5,1875 & 1,0468 & 1,0958 & 0,0685 & 0,2617 & $-3,10^{*}$ \\
\hline 17 & 4,8125 & 1,6008 & 2,5626 & 0,1602 & 0,4002 & $-2,97^{*}$ \\
\hline 18 & 7,3125 & 0,8732 & 0,7625 & 0,0477 & 0,2184 & $+6,01^{*}$ \\
\hline
\end{tabular}

OBS: $\mathrm{t}_{\text {Tabela }}(15 \mathrm{gL}, 1 \%)=2,95 ; \mathrm{t}_{\text {Tabela }}(15 \mathrm{gL}, 10 \%)=1,75$

${ }^{*}=$ significativo ao nível de $1 \%$ de probabilidade.

** = significativo ao nível de $10 \%$ de probabilidade.

${ }^{\mathrm{ns}}=$ não significativo 


\subsubsection{Análise de fatores}

O perfil de qualidade das aguardentes não é uma variável mensurável, devido o caráter multidimensional do conceito, mas a partir das variáveis observadas, suportamente importante para descrever o conceito citado, construiu-se 2 novas variáveis não mensuráveis chamadas fatores $\left(F_{1}\right.$ e $\left.F_{2}\right)$. $O$ conjunto de 10 variáveis consideradas, foram:

$\mathrm{X}_{1}$ : Análise Sensorial (notas)

$\mathrm{X}_{2}:$ Acidez $\quad(\mathrm{mg} \mathrm{HAc} / 100 \mathrm{~mL})$

$\mathrm{X}_{3}$ : Aldeído acético $\quad(\mathrm{mg} / 100 \mathrm{~mL}$ grau real $)$

$\mathrm{X}_{4}$ : Acetona $\quad(\mathrm{mg} / 100 \mathrm{~mL}$ grau real $)$

$\mathrm{X}_{5}$ : Éster $\quad(\mathrm{mg} / 100 \mathrm{~mL}$ grau real $)$

$\mathrm{X}_{6}:$ Metanol $\quad(\mathrm{mg} / 100 \mathrm{~mL}$ grau real $)$

$\mathrm{X}_{7}: \mathrm{N}$-propanol $\quad(\mathrm{mg} / 100 \mathrm{~mL}$ grau real $)$

$\mathrm{X}_{8}$ : I-Butanol $\quad(\mathrm{mg} / 100 \mathrm{~mL}$ grau real $)$

$\mathrm{X}_{9}$ : I-Amílico $\quad(\mathrm{mg} / 100 \mathrm{~mL}$ grau real $)$

$\mathrm{X}_{10}$ : Álcoois Superiores $\quad(\mathrm{mg} / 100 \mathrm{~mL}$ grau real)

A partir do conjunto das variáveis consideradas, obteve-se a matriz de correlações simples entre as dez variáveis, conforme Tabela 41. 


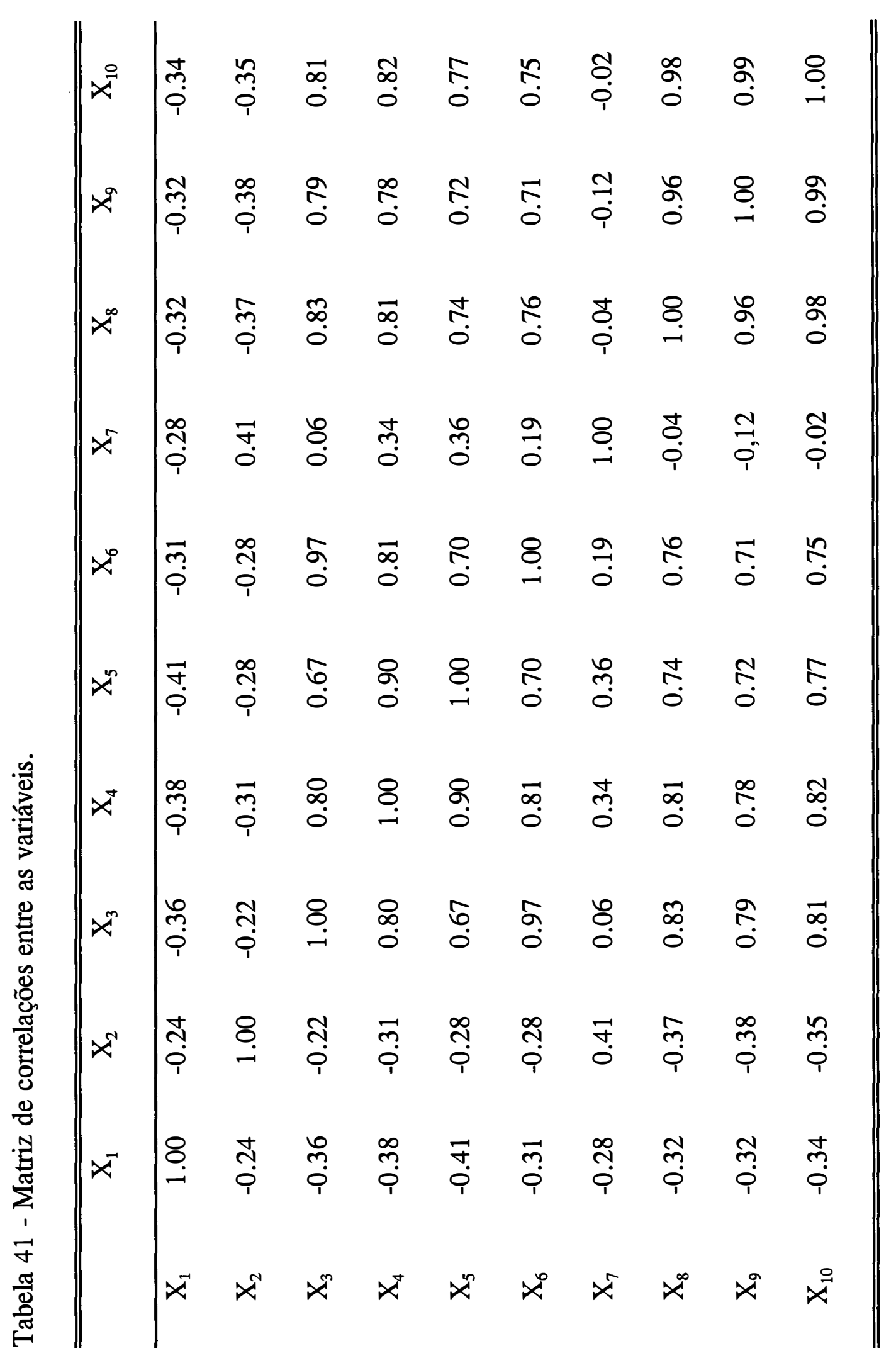


$\mathrm{Na}$ análise, optou-se por considerar apenas dois fatores, $\mathrm{F}_{1}$ e $\mathrm{F}_{2}$, por melhor explicarem a variância total das 10 variáveis iniciais. Para facilidade de interpretação foi feita a rotação varimax, a partir da qual obteve-se as cargas fatoriais dos dois fatores, bem como as comunalidades de cada variável explicada pelos dois fatores, conforme dados da Tabela 42 .

Tabela 42 - Cargas fatoriais de fatores e comunalidades.

\begin{tabular}{|c|c|c|c|c|c|c|}
\hline \multirow[b]{2}{*}{ Variável } & \multicolumn{2}{|c|}{ Cargas Fatoriais } & \multicolumn{3}{|c|}{ Comunalidade } & \multirow{2}{*}{$\begin{array}{c}\text { Especifi- } \\
\text { cidade }\end{array}$} \\
\hline & $\mathrm{F}_{1}$ & $\mathrm{~F}_{2}$ & $\mathrm{~F}_{1}$ & $\mathrm{~F}_{2}$ & TOTAL & \\
\hline $\mathrm{X}_{1}$ & -0.39108 & -0.58695 & 0.1529 & 0.3445 & 0.4974 & 0.5026 \\
\hline $\mathrm{X}_{2}$ & -0.39515 & 0.71558 & 0.1561 & 0.5121 & 0.6682 & 0.3318 \\
\hline$X_{3}$ & 0.90479 & 0.06284 & 0.8186 & 0.0039 & 0.8225 & 0.1774 \\
\hline$X_{4}$ & 0.91641 & 0.20829 & 0.8398 & 0.0434 & 0.8832 & 0.1168 \\
\hline$X_{5}$ & 0.85200 & 0.25021 & 0.7259 & 0.0626 & 0.7885 & 0.2115 \\
\hline$X_{6}$ & 0.87863 & 0.10748 & 0.7720 & 0.0115 & 0.7835 & 0.2164 \\
\hline $\mathrm{X}_{7}$ & 0.07988 & 0.85834 & 0.0064 & 0.7367 & 0.7431 & 0.2569 \\
\hline$X_{8}$ & 0.95381 & -0.11466 & 0.9097 & 0.0131 & 0.9228 & 0.0771 \\
\hline $\mathrm{X}_{9}$ & 0.93511 & -0.16640 & 0.8744 & 0.0228 & 0.9022 & 0.0979 \\
\hline$X_{10}$ & 0.95862 & -0.08544 & 0.9189 & 0.0073 & 0.9262 & 0.0737 \\
\hline \multicolumn{3}{|c|}{ Variância Explicada } & 6.1749 & 1.7629 & 7.9378 & 2.0622 \\
\hline \multicolumn{3}{|c|}{ \% variância explicada } & 61.75 & 17.63 & 79.38 & \\
\hline
\end{tabular}


Verifica-se que o fator $F_{1}$ está fortemente correlacionado em sentido positivo com as seguintes variáveis $\mathrm{X}_{3}, \mathrm{X}_{4}, \mathrm{X}_{5}, \mathrm{X}_{6}, \mathrm{X}_{8}, \mathrm{X}_{9}$ e $\mathrm{X}_{10}$, enquanto o fator $F_{2}$, está positivo e fortemente correlacionado com as variáveis $X_{2}$ e $X_{7}$ e negativamente correlacionado com $X_{1}$, ou seja, quanto maior o $F_{2}$, menor é $X_{1}$.

A Tabela 43 mostra os valores dos dois fatores $F_{1}$ e $F_{2}$, para cada um dos aguardentes, que encontram-se representados na Figura 27.

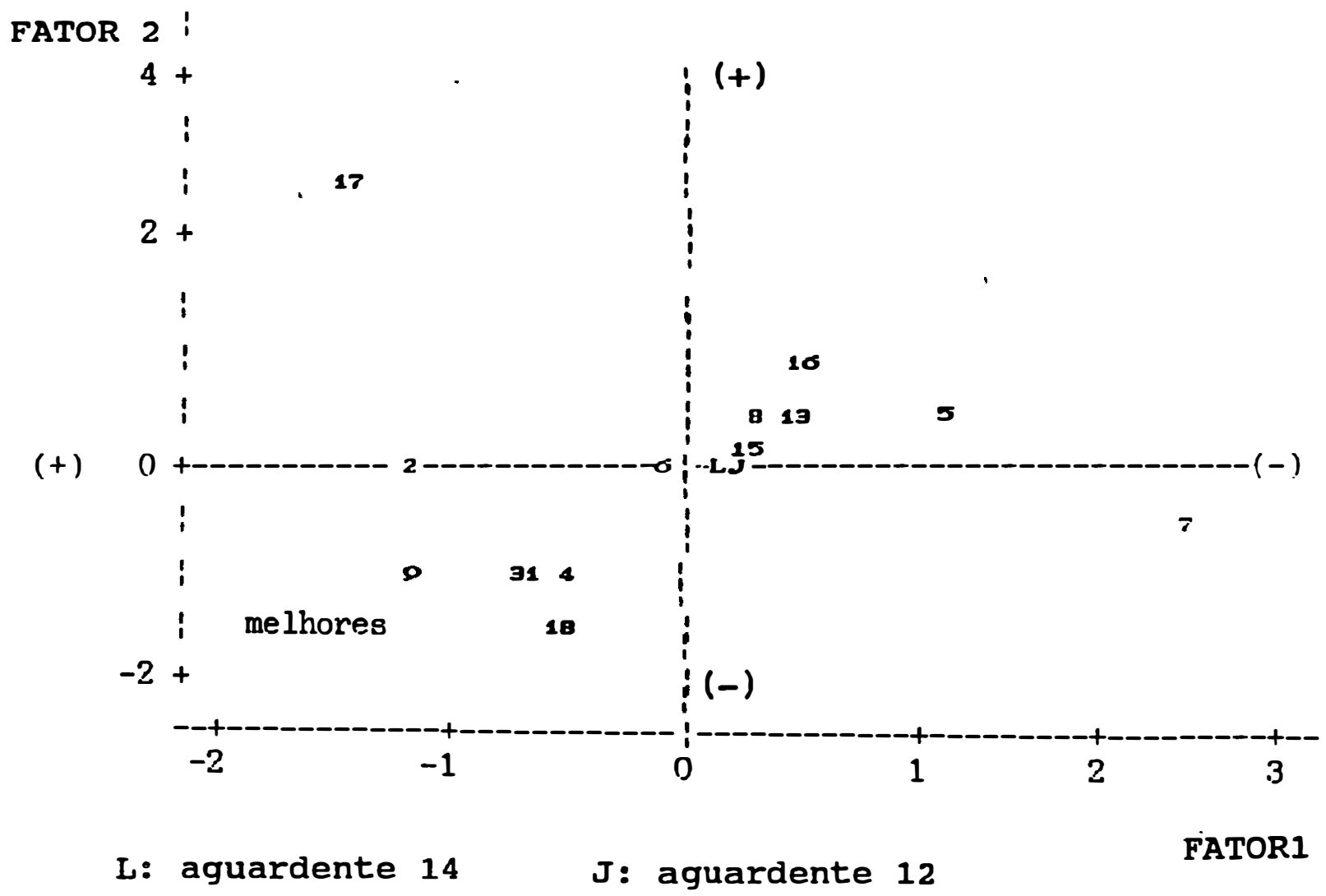

Figura 27 - Valores de $F_{1}$ e $F_{2}$ para as aguardentes. 
Pode-se verificar pela Figura 27, que:

- As aguardentes 1, 3, 4, 9 e 18, agrupadas no quadrante 3 , obtiveram valores negativos nos dois fatores. Essas aguardentes, quando submetidas a análise sensorial obtiveram maiores médias de nota.

- A aguardente 17 tem aspectos negativos de $F_{1}$ e muito positivo de $F_{2}$, convertendose em uma aguardente diferente das demais.

- A aguardente 7, está fortemente representado por todas as variáveis que compõe $F_{1}$, apesar do valor negativo para $F_{2}$.

- As aguardentes 6, 8, 12, 14 e 15 formam um agrupamento de grau médio quanto a $F_{1}$ e $F_{2}$, pois apresentam valores perto de zero para os dois fatores.

A partir da análise dos fatores $F_{1}$ e $F_{2}$, verificou-se que a variável $X_{1}$ (análise sensorial), mesmo não sendo bem representada em $F_{1}$, ela é importante na composição de $F_{2}$, sendo que os fatores $F_{1}$ e $F_{2}$ em conjunto conseguem captar 49,7\% da variação da análise sensorial, ou seja, é necessário ampliar o número de variáveis observadas para aumentar o coeficiente de correlação entre os dados analíticos e sensoriais. 
Tabela 43 - Valores obtidos para os fatores ao nível dos aguardentes.

\begin{tabular}{ccc}
\hline \hline Aguardente & Fator 1 & Fator 2 \\
\hline 1 & -0.61531 & -0.96068 \\
2 & -1.18383 & 0.20596 \\
3 & -0.65672 & -0.87547 \\
4 & -0.42327 & -1.14344 \\
5 & 1.12930 & 0.53875 \\
6 & -0.06145 & -0.20291 \\
7 & 2.63906 & -0.42349 \\
8 & 0.41434 & 0.41292 \\
9 & -1.16986 & -0.85153 \\
12 & 0.23609 & 0.13472 \\
13 & 0.43837 & 0.59122 \\
14 & 0.17021 & 0.22834 \\
15 & 0.38261 & 0.35596 \\
16 & 0.55112 & 0.76411 \\
17 & -1.36469 & 2.69520 \\
18 & -0.48598 & -1.46967 \\
\hline
\end{tabular}

A partir das dificuldades inerentes das análises sensorial e química das aguardentes, pois essas requerem complexas técnicas de preparação das amostras bem como sofisticada e dispendiosa instrumentação, não disponíveis, na determinação de compostos voláteis, importantes componentes na qualidade da bebida, nos cabe salientar a importância da utilização de métodos estatísticos multivariados para caracterização e distinção de bebidas destiladas a partir da concentração de um número menor de componentes da bebida. 
A partir da análise dos fatores $F_{1}$ e $F_{2}$ e do estudo do comportamento dos principais compostos voláteis durante a destilação, verificou-se algumas tendências gerais:

- Os teores de n-propanol e de acidez, variáveis que compõem o Fator $\mathrm{F}_{2}$, formam um contraste em relação à qualidade sensorial da aguardente, sendo que a correlação entre teores n-propanol e qualidade de aguardentes já foi observada por Almeida \& Barreto (1971), que relatam a ocorrência de maiores teores de n-propanol em aguardentes de qualidade inferior.

- A acidez da aguardente deve ser monitorada através da otimização das condições de fermentação, bem como as de destilação, cortando a destilação com produto em alto grau e posteriormente ajustando com água de qualidade para o grau alcoólico requerido, reduzindo assim os teores de cobre, de acidez e obtendo-se um produto de melhor qualidade sob aspecto sensorial bem como de saúde pública.

- O n-propanol, em virtude de suas características físicas, destila com alto grau de uniformidade (vide Figura 11); logo, o controle de seu teor será mais eficiente na operação de fermentação no processo de obtenção de aguardente.

- Os teores de acidez e de propanol podem ser ainda reduzidos na aguardente através da bidestilação, fracionado-se o destilado com subsequente remoção da fração cabeça (vide Figuras 13 e 17). 


\section{CONCLUSÕES}

1) A fração cabeça do destilado é importante na composição do flavor da bebida.

2) A remoção de células de leveduras do vinho influi no flavor do produto, porém é desejável estudo complementar quanto à porcentagem de células adequada à obtenção de um produto de melhor flavor.

3) Não foi possível caracterizar a influência dos compostos voláteis da matéria-prima sobre o flavor das aguardentes, sendo desejáveis estudos complementares a nível de variedade de cana, grau de maturação, entre outros.

4) É necessário aumentar o número de variáveis observadas, ou seja, o número de componentes analisados da aguardente, para aumentar o coeficiente de correlação entre os dados analíticos e sensorial, viabilizando a agilização no controle e/ou monitoramento das condições de condução da operação destilação, bem como das demais operações que compõe a produção de aguardente. 
5 - A acidez e o teor de propanol influem negativamente no flavor da aguardente.

6 - A extensão de remoção da fração cauda influi no grau de acidez da aguardente, bem como a bidestilação, a qual, através do fracionamento do bidestilado, com remoção da fração cabeça, reduz a acidez do produto.

7 - Os teores de acidez e de cobre numa aguardente guardam uma relação direta.

8 - O teor de cobre na aguardente pode ser reduzido através do maior grau de remoção da fração cauda, sem prejudicar o rendimento em etanol.

9 - Compostos voláteis desconhecidos e em menores teores que os álcoois superiores são importantes para caracterização das aguardentes.

10 - A concentração etanol no vinho influi quantitativamente e qualitativamente no destilado obtido e são necessários estudos para determinar o teor de etanol ideal no vinho, equacionando eficiência de destilação (rendimento + produtividade) e qualidade do produto.

11 - Acidez total da aguardente mantém proporcionalidade com a acidez do vinho; assim, é importante o controle de acidez em operação anterior à destilação no processo de obtenção de aguardente. 


\section{REFERÊNCIAS BIBLIOGRÁFICAS}

ALMEIDA, J.R. de. Destilação dos vinhos para obtenção das aguardentes. Revista Tecnologia das Bebidas, v.5, n.1, p.7-9, 1952.

ALMEIDA, M.E.W. de; BARRETO, H.H.C. Determinação de álcoois superiores em aguardentes de frutas por cromatografia em fase gasosa. Revista do Instituto Adolfo Lutz, v.33, p.73-84, 1973.

ALMEIDA, J.R. de; VALSECCHI, O.; NOVAIS, R.F. Envelhecimento das aguardentes. Anais da Escola Superior de Agricultura "Luiz de Queiroz", v.4, p.11-83, 1947.

ALMEIDA, M.E.W. de; BARRETO, H.H.C. Álcoois superiores em aguardente de cana por cromatografia em fase gasosa. Revista do Instituto Adolfo Lutz, v.31, p.117-24, 1971.

AMERINE, M.A.; BERG, H.W.; CRUESS, W.V. The technology of wine making. 3.ed., Westport, The AVI Publ., 1972.

ANDERSON, T.W. An introduction to multivariate statistical analysis. 2.ed., New York, John Wiley \& Sons, 1984. 390p. 
ANDRADE, J.B. de; BRAVO, R.V.F. Análise de aldeídos em bebidas alcoólicas: um experimento de cromatografia líquida de alta eficiência para cursos de graduação. Química Nova, v.12, n.2, p.196-98, 1989.

ARROYO, R. The manufacture of rum. Sugar, v.37, n.5, p.26-9,33, 1942.

ASKEW, B.; LISLE, D.B. Variation in the concentrations of higher alcohols, methanol and ethyl acetate in brandies. Journal of the Science of Food and Agriculture, v.22, n.2, p.102-4, 1971.

AYLOTT, R.I.; COCHRANE, G.C.; DONE，J.N.; MACKENZIE，W.M.; WALKER, D.A. Quality assurance in chromatographic whisky analysis. Analytical Proceedings, v.24, p.166-7, 1987.

BRASIL. Leis, decretos, etc. Lei $n^{\circ}$ 5812, de 14 nov. 1972. Dispõe sobre instrumenções de orientação para o registro e cadastramento dos estabelecimentos de bebidas.

BRASIL. Leis, decretos, etc. Portaria $n^{0} 076$ de 27 nov. 1986. Diário Oficial da União, Brasîlia, 03 de dez., 1986.

CAPLA, I.; HAUSKRECHT, P.; WILD, J. Method for reducing the $\mathrm{SO}_{2}$ concen. in ethanol distillates. Czechoslovak Patent (SK), CS218.062. 1983. Apud Food Science and Technology Abstracts, v.16, n.12, p.57, 1984 (Resumo).

CARNACINI, A.; DI S'TEFANO, R.; RIPONI, C.; ANTONIELLI, A. Effect of the wine making process on the volatile compounds of distillates. Italian Journal of Food Science, v.1, n.4, p.13-22, 1989. 
CELESTINE-MYRTIL, D.A.; PARFAIT, A. HPLC analysis of sugars in sugar cane stalks. International Sugar Journal, v.89, p.186-9, 1987.

CONSIDERAÇÃO histórica em torno dos destilados. Engarrafador Moderno, p.42-50, jun. 1978.

DAHER, A.L.K.; FREITAS, R.J.S. de. Determinação do cobre em bebidas. Arquivos de Biologia e Tecnologia, v.23, n.1, p.1-9, 1980.

DAUDT, C.E.; OUGH, C.S. Efeitos da variedade de microrganismos, temperatura, $\mathrm{SO}_{2}$ e variedade de uva sobre a formação de álcoois superiores. Revista Brasileira de Tecnologia, v.6, n.4, p.301-5, 1975.

DOTT, W.; HEINZEL, M.; TRÜPER, H.G. Sulfite formation by wine yeasts. Archives of Microbiology, v.107, n.3, p.289-2, 1976.

FARIA, J.B. A influência do cobre na qualidade das aguardentes de cana (Saccharum officinarum, L.). São Paulo, 1989, 88p. Tese - (Doutorado) Faculdade de Ciências Farmacêuticas, Universidade de São Paulo.

FARIA, J.B.; LOURENÇO, E.J. Influência do cobre na qualidade das aguardentes de cana (Saccharum officinarum, L.). Alimentos e Nutrição, v.2, p.93-100, 1990.

FEUILLAT, M.; CHARPENTIER, C. Autolysis of yeasts in champagne. American Journal of Enology and Viticulture, v.33, n.1, p.6-12, 1982. 
FONSECA, H.; CAMARGO, R. de; OLIVEIRA, A.J. de; NOGUEIRA, J.N. A influência do vasilhame de cloreto de polivinila na qualidade do aguardente e da vodca. Piracicaba, FEALQ/CPC/RIONIL, 1985. $1 \mathrm{v}$.

FOURNIER, L.B.; VIDAURRETA, L.E. Colorimetric determination of aconitic acid in sugar cane juice. Analytica Chimica Acta, v.53, p.387-92, 1971.

FURTADO, S.M.B. Avaliação sensorial descritiva de aguardente de cana (Saccharum officinarum L.). Influência da composição em suas características sensoriais e correlação entre as medidas sensoriais e físico-químicas. Campinas, 1995. 99p. Tese (Doutorado) - Faculdade de Engenharia de Alimentos, Universidade Estadual de Campinas.

GARRICK, C.C. Developments in the brewing industry. Food Technology in Australia, v.32, n.7, p.346-50, 1980.

GODOY, A. Avaliação dos microrganismos contaminantes da fermentação alcoólica e seus efeitos sobre a qualidade das aguardentes. Jaboticabal, 1992. 93p. (Iniciação Cient́fica, Faculdade de Ciências Agrárias e Veterinárias, Universidade Estadual Paulista "Júlio de Mesquita Filho".

GOMES, F.P. Curso de Estatística Experimental. 13.ed., Piracicaba: Nobel, 1990. Cap.3, p.18-41: Os testes ou provas de significância.

GUYMON, J.F. Higher alcohols in beverage brandy. Wines \& Vines, v.53, n.1, p.37-40, 1972. 
GUYMON, J.F. Chemical aspects of distilling wines into brandy. In: WEBB, A.D. ed. Chemistry of Winemaking, Washington, American Chemical Society, 1974, p.232-53. (Advances in Chemistry, séries 137).

GUTIERREZ, L.E. Produção de álcoois superiores por linhagens de Saccharomyces durante a fermentação alcoólica. Scientia Agricola, v.50, n.3, p.464-72, 1993.

HASHIZUME, T. Considerações sobre ésteres nas bebidas alcoólicas. Instruções Técnicas, n.9, p.109-21, 1976.

HIRSCH, I. Manufacture of whiskey, brandy and cordials. Newark, Sherman Eng., 1937. 183p.

INSTITUTO ADOLFO LUTZ. Normas Analíticas do Instituto Adolfo Lutz, 3.ed., São Paulo, 1985. 533p.

KILLIAN, E.; OUGH, C.S. Fermentation esters-formation and retention as affected by fermentation temperature. American Journal of Enology and Viticulture, v.30, n.4, p.301-5, 1979.

KLOSOWSKY, G.; CZUPRYNSKI, B. Reasons of carbonyl compounds formation in crude spirit with a special attention to acetaldehyde. Przemysl Fermentacyjny i Owocowo-Warzywny, v.37, n.5, p.8-10, 1993. Apud Food Science and Technology Abstracts, v.26, n.8, p.103, 1994. (Resumo). 
LÉAUTÉ, R. Distillation in alambic. American Journal of Enology and Viticulture, v.41, n.1, p.90-103, 1990.

LEES, P.M. Influência da substância nitrogenada em um fermentado de hidromel sobre as características de seu destilado alcoólico. Brasil Açucareiro, v.22, n.3, p.209-12, setembro 1943.

LIMA, U. de A. Aguardentes. In: AQUARONE, E.; LIMA, U. de A.; BORZANI, V. "Alimentos e bebidas produzidos por fermentação". São Paulo, Edgar Blücher, 1983, 227p. (Série Biotecnologia, 5).

LIMA, U. de A. Estudos dos principais fatores que afetam os componentes do coeficiente não álcool das aguardentes de cana. Piracicaba, 1964. 141p. (Cátedra - Escola Superior de Agricultura "Luiz de Queiroz", Universidade de São Paulo.

LIMA NETO, B. dos S.; FRANCO, D.W. A aguardente e o controle químico de sua qualidade. Engarrafador Moderno, v.4, n.33, p.5-8, 1994.

LLISTÓ, A.M.S.M.; SOUZA, L.G. de; MISCHAN, M.M. Alguns componentes do coeficiente não-álcool das aguardentes de cana: Ésteres. Brasil Açucareiro, v.92, n.5, p.341-6, 1979.

LUCENA, V.G. de. Componentes secundários das aguardentes. Brasil Açucareiro, v.49, n.2, p.2-4, 1957. 
LUCENA, V.G. de. O problema do cobre nas aguardentes. Brasil Açucareiro, v.53, n.6, p.14-8, 1959.

MAIA, A.B. Componentes secundários da aguardente. STAB, v.12, n.6, p.29-34, 1994.

MAIA, A.B.R.A.; PEREIRA, A.M.; LIMA, C.A.A.; CARVALHO, J.S.; RINCON, R.G.; CARVALHO, P.D.; NELSON, D.L. Fermentação alcoólica semi-contínua destinada a produção de aguardente. Boletim da Sociedade Brasileira de Ciência e Tecnologia de Alimentos, v.25, n.1, p.33-6, 1991.

MANE, J.D.; PHADNIS, S.P.; JADHAV, S.J. Effects of hydrogen peroxide on cane juice constituents. International Sugar Journal, v.94, n.128, p.322-4, 1992.

MANITTO, P.; CHIALVA, F.; SPERANZA, G.; RINALDO, C. Absolute stereochemistry and enantiomeric excess of 2-Butanol in distilled spirits of different origin. Journal of Agricultural and Food Chemistry, v.42, n.4, p.886-9, 1994.

MARGALITH, P.; SCHWARTZ, Y. Flavor and microorganisms. Advances in Applied Microbiology, v.12, p.35-88, 1970.

MARLY-BRUGEROLLE, C.; SARRE, C.; BERTRAND, A. Influencie of preclarification of mustus and of sulphite treament on content of volatile substances of wines and brandies. II. Brandies Connaissance de la Vigne et du Vin. v.12, n.2, p.111-20, 1978. Apud Food Science and Technology Abstracts, v.12, n.4, p.78, 1979 (Resumo). 
MNDZHOYAN, E.L.; SAAKYAN, A.S. Terpenoid compounds in freshly distilled brandy spirit. In: . Biokhimicheskie osnovy kon'yachnogo proizvodstva, p.175-7, 1972. Apud Food Science and Technology Abstracts, v.5, n.10, p.51, 1973.

MNDZHOYAN, E.L.; RODOPULO, A.K.; BEZZUBOV, A.A. Effect of autolysates on quality of brandy spirits. In: . Biokhimicheskie osnovy kon'yachnogo proizvodstva, p.156-69, 1972. Apud Food Science and Technology Abstracts, v.5, n.10, p.53, 1973.

MORRISON, R.T.; BOYD, R.N. Química Orgânica. 7.ed., Lisboa, Fundação Calouste Gulbenkian, 1973.

MOUTOUNET, M.; ESCUDIER, J.L.; JOURET, C. Production of spirits by pervaporation. Comparison with still distillation. Lebensmittel Wissenschaft und Technologie, v.25, p.71-3, 1992.

MURTA, A.L.M.; KUGLER, W.; LINSINGEN, U.I.B. von; BERG, R.G. Determinação da composição de aguardentes de cana-de-açúcar por cromatografia gasosa. Arquivos de Biologia e Tecnologia, v.25, n.2, p.221-6, 1982.

NÓBREGA, I.C. da. C. Características de qualidade de aguardentes de cana comerciais e comparação entre dois processos de fermentação. Viçosa, 1994. 67p. Dissertação - (Mestrado) - Universidade Federal de Viçosa. 
NÓBREGA, I.C. da C.; SILVA, P.H.A. Presença de cobre em aguardente de cana. In: CONGRESSO BRASILEIRO DE CIÊNCIA E TECNOLOGIA DE ALIMENTOS, 14., São Paulo. 1994. Anais. São Paulo, SBCTA, 1994. p.159.

NOVAES, F.V.; OLIVEIRA, E.R.; STUPIELLO, J.P.; VALSECCHI, O. I Curso de extensão em tecnologia de aguardente de cana: apontamentos. Piracicaba, ESALQ, 1974. 104p.

NYKÄNEN, L.; NYKÄNEN, I.; SUOMALAINEN, H. Distribuiton of esters produced during sugar fermentation between the yeast cell and the medium. Journal of the Institute of Brewing, v.83, p.32-4, 1977.

NYKÄNEN, L.; PUPUTTI, E.; SUOMALAINEN, H. Volatile fatty acids in some brands of whisky, cognac and rum. Journal of Food Science, v.33, p.88-92, 1968.

NYKÄNEN, L.; NYKÄNEN, I. Production of esters by different yeast strains in sugar fermentations. Journal of the Institute of Brewing, v.83, p.30-31, 1977.

NYKÄNEN, L.; NYKÄNEN, I. Distilled Beverages. In: MAARSE，H. ed. Volatile Compounds in Foods and Beverages, New York, Marcell Dekker Inc., 1991. cap. 15.

OSSA, E.M. de la; SERRANO, M.A.G. Salt effect on the composition of alcohols obtained from wine by extractive distillation. American Journal of Enology and Viticulture, v.42, n.3, p.252-4, 1991. 
PACKOWSKI, G.W. Beverage spirits, distilled. In: KIRK-OTHMER. Encyclopedia of chemical technology, 3.ed. New York, John Wiley \& Sons, 1978. vol.3, p.830-63.

PAULING, L. Química Geral. Rio de Janeiro, Ao Livro Técnico \& EDUSP, 1966. cap.17, p.383-403: Enxôfre, Selênio e Telúrio.

PEDUTI, F. Contrôle quantitativo de cobre em aguardentes. Revista do Instituto Adolfo Lutz, v.3, n.1, p.216-23, 1943.

"PINGA: sem ressaca da crise". Alimentos \& Tecnologia, v.3, n.20, p.42-5, 1988.

QUAIN, D.E. Studies on yeast physiology-impact on fermentation performance and product quality. Journal of the Institute of Brewing, v.95, p.315-23, 1988.

RAMSAY, C.M.; BERRY, D.R. The effect of inoculum level on the formation of higher alcohols, fatty acids and ésters in the malt whisky fermentation. Food Microbiology, v.1, p.111-5, 1984.

RAMSAY, C.M.; BERRY, D.R. Effect of temperature and $\mathrm{pH}$ on the formation of higher alcohols, fatty acids and esters in the malt whisky fermentation. Food Microbiology, v.1, p.117-121, 1984. 
REAZIN, G.H. Formation of major congeners during fermentation. Abstracts of Papers American Chemical Society, Kentucky, 158:MICR26, 1969. Apud Food Science and Technology Abstracts, Shinfield, v.2, n.2, p.200, 1970 (Resumo).

REED, G.; NAGODAWITHANA, T.W. Distiller's yeasts. In: Yeast Technology, 2.ed. New York, AVI Book, 1991. cap.5.

RIBEIRO, D. 'Caninha nunca terá boa qualidade', afirma especialista. Folha de São Paulo: Suplemento de Turismo, 18 fev. 1993. p.5-5.

ROSE, A.H. Alcoholic beverages. London, Academic Press, 1977. 760p. (Economic Microbiology, 1).

1 ROSI, I.; BERTUCCIOLI, M. Influences of lipid addition on fatty acid composition of Saccharomyces cerevisiae and aroma characteristics of experimental wines. Journal of the Institute of Brewing, v.98, n.4, p.305-14, 1992.

SACHAVO, M.S. Method of obtaining brandy alcohol. USSR Patent, n.572.497, 1977. Apud Food Science and Technology Abstracts, v.10, n.3, p.43, 1978. (Resumo).

SAMARAJEEWA, U.; ADAMS, M.R.; ROBINSON, J.M. Major volatiles in Sri Lankan arrack, a palm wine distillate. Journal of Food Technology, v.16, p.437-44, 1981 . 
SERPE, E.R.; FREITAS, R.J.S. de. Avaliação do cobre e zinco em alimentos de consumo diário. Boletim do Centro de Pesquisa e Processamento de Alimentos, v.9, n.2, p.141-8, 1991.

SIMPSON, A.C. Manufacture of brandy. Process Biochemistry, v.6, n.2, p.25-7, 1971.

SISAKYAN, N.M.; KVANTALIANI, N.M.; BERIDZE, G.I. Changes in nitrogen compounds of wines during distillation to brandy spirits. In:

Biokhimicheskie osnovy kon'yachnogo proizvodstva, p.122-7, 1972. Apud Food Science and Technology Abstracts, v.5, n.10, p.50, 1973.

SOUZA, L.G. de; LLISTÓ, A.M.S.M. Alguns componentes do coeficiente não álcool das aguardentes de cana. Determinação por cromatografia em fase gasosa. Brasil Açucareiro, v.91, n.3, p.13-6, 1978.

STRAUSS, C.R.; WILLIAMS, P.J. The effect of destillation on grape flavour components. In: PIGGOTT, J.R. ed. Flavour of distilled beverages: origin and development. Chichester, Ellis Horwood Ltd, 1983. cap.8.

SUOMALAINEN, H. Yeast and its effect on the flavour of alcoholic beverages. Journal of the Institute of Brewing, v.77, n.2, p.164-77, 1971. 
SUOMALAINEN, H. Yeast esterases and aroma esters in alcoholic beverages. Journal of the Institute of Brewing, v.87, p.296-300, 1981.

SUOMALAINEN, H.; LEHTONEN, M. The production of aroma compounds by yeast. Journal of the Institute of Brewing, v.85, n.3, p.149-56, 1979.

SUOMALAINEN, H.; NYKÄNEN, L.; ERIKSSON, K. Composition and consumption of alcoholic beverages. A review. American Journal of Enology and Viticulture, v.25, n.4, p.179-87, 1974.

SUOMALAINEN, H.; NYKÄNEN, L. The aroma components produced by yeast in nitrogen-free sugar solution. Journal of the Institute of Brewing, v.72, p.469-74, 1966.

SUOMALAINEN, H.; NYKÄNEN, L. Composition of whisky flavour. Process Biochemistry, v.5, n.7, p.13-8, 1970.

SUOMALAINEN, H.; NURMINEN, T. Some aspects of the structure and function of the yeast plasma membrane. Journal of the Institute of Brewing, v.82, n.4, p.218-25, 1976.

STUPIELLO, J.P. Aspectos da fermentação e da destilação da aguardente de cana. Saccharum, v.2, n.7, p.34-6, 1979. 
TANNER, H. Production of satisfactory distillates. Schweizerische Zeitschrift für Obst - und Wienbau, v.105, n.14, p.319-28, 1969. Apud Food Science and Technology Abstracts, v.2, n.2, p.199, 1970. (Resumo).

TAYLOR, G.T.; KIRSOP, B.H. The origin of the medium chain lenght fatty acids present in beer. Journal of the Institute of Brewing, v.83, p.241-43, 1977.

TOKITOMO, Y.; KOBAYASHI, A.; YAMANISHI, T. Aroma components of fresh sugar cane juice. Agricultural and Biological Chemistry, v.48, n.11, p.2869-70, 1984.

UNGER, E.D.; COFFEY, T.R. Production of light-bodied rum by an extractive distillation process. Annales de Technologie Agricole, v.24, n.3/4, p.469-95, 1975.

VOSTI, D.C.; JOSLYN, M.A. Autolysis of baker's yeast. Applied Microbiology, v.2, p.70-8, 1954.

WANWRIGHT, T. Production of $\mathrm{H}_{2} \mathrm{~S}$ by yeasts: role of nutrients. Journal of Applied Bacteriology, v.34, n.1, p.161-71, 1971.

WEBB, A.D.; MULLER, C.J. Volatile aroma components of wines and other fermented beverages. Advances in Applied Microbiology, v.15, p.75-142, 1972. 
WILLIAMS， P.J.; STRAUSS， C.R. 3,3-Diethoxybutan-2-one and 1,1,3triethoxypropane: Acetals in Spirits Distilled from Vitis vinifera Grape Wines. Journal of the Science of Food and Agriculture, v.26, p.1127-36, 1975.

WILLIAMS, P.J.; STRAUSS, C.R. A treatment of grape wine distillation heads. Journal of the Science of Food and Agriculture, v.27, n.6, p.487-98, 1976.

WILLIAMS, A.A.; ROSSER, P.R. Aroma enhancing effects of ethanol. Chemical Senses, v.6, n.2, p.149-53, 1981.

WHITING, G.C. Organic acid metabolism of yeasts during fermentation of alcoholic beverages. A review. Journal of the Institute of Brewing, v.82, n.2, p.84-92, 1976.

ZEE, J.A.; SIMARD, R.E.; CARBILLET, L.; LEBEL, C.; LIBER, E. Comparative composition of fusel oils in brandies made from six grape varieties and their relationship with sensory analysis. Lebensmittel Wissenschaft und Technologie, v.15, p.54-9, 1984. 


\section{APÊNDICES}




\section{APÊNDICE A}

Tabela 1-A: Resultados da Condução das Fermentações.

\begin{tabular}{|c|c|c|c|}
\hline Aguardente & $\begin{array}{c}\text { Brix Mosto } \\
\text { Inicial }\end{array}$ & $\begin{array}{c}\text { Álcool vinho } \\
(\% \mathrm{v})\end{array}$ & $\begin{array}{l}\text { Acidez do vinho } \\
\text { mg HAc/100 ml }\end{array}$ \\
\hline 01 & 14,4 & 7,56 & 14,40 \\
\hline 02 & 14,2 & 7,41 & 14,40 \\
\hline 03 & 14,3 & 8,92 & 17,81 \\
\hline 04 & 14,4 & 8,20 & 11,40 \\
\hline 05 & 14,4 & 8,20 & 11,70 \\
\hline 06 & 14,3 & 8,92 & 18,60 \\
\hline \multirow[t]{3}{*}{07} & 14,4 & 7,06 & 20,04 \\
\hline & 14,3 & 8,50 & 20,10 \\
\hline & 14,2 & 8,20 & 20,36 \\
\hline \multirow{2}{*}{08} & 14,3 & 7,34 & 20,25 \\
\hline & 14,2 & 7,06 & 19,94 \\
\hline 10 & 14,3 & 8,78 & 17,81 \\
\hline 11 & 14,3 & 8,92 & 13,36 \\
\hline 12 & 14,5 & 8,34 & 16,08 \\
\hline 13 & 14,4 & 7,90 & 21,21 \\
\hline 14 & 14,4 & 8,50 & 16,20 \\
\hline 15 & 14,5 & 8,92 & 16,54 \\
\hline 16 & 14,6 & 9,08 & 16,50 \\
\hline 18 & 18,9 & 10,24 & 24,24 \\
\hline
\end{tabular}




\section{APÊNDICE B}

Tabela 1-B: Resultados dos Rendimentos das Destilações.

\begin{tabular}{ccccc}
\hline \hline Aguardente & $\begin{array}{c}\text { Álcool } \\
\text { vinho } \\
(\% \mathrm{v})\end{array}$ & $\begin{array}{c}\text { Álcool } \\
\text { destilado } \\
(\% \mathrm{v})\end{array}$ & $\begin{array}{c}\text { Volume } \\
\text { destilado } \\
(\mathrm{ml})\end{array}$ & $\begin{array}{c}\text { Rendimento } \\
\text { Destilação } \\
(\%)\end{array}$ \\
\hline 01 & 7,56 & 49,01 & 1500 & 81,03 \\
02 & 7,41 & 45,59 & 1200 & 61,52 \\
03 & 8,92 & 46,25 & 1800 & 77,77 \\
04 & 8,20 & 52,48 & 1600 & 85,33 \\
05 & 8,20 & 50,44 & 1500 & 76,90 \\
06 & 8,92 & 63,10 & 1000 & 58,90 \\
10 & 8,78 & 50,54 & 1600 & 76,75 \\
11 & 8,92 & 50,44 & 1555 & 73,28 \\
12 & 8,34 & 49,11 & 1600 & 78,50 \\
13 & 7,90 & 51,38 & 1600 & 86,70 \\
14 & 8,50 & 49,01 & 1600 & 76,90 \\
15 & 8,92 & 52,58 & 1600 & 78,60 \\
16 & 9,08 & 51,79 & 1600 & 76,05 \\
18 & 10,24 & 62,66 & 1600 & 81,59 \\
\hline \hline
\end{tabular}

Tabela 2-B: Resultados dos Rendimentos das Destilações. (Aguardentes bidestiladas).

\begin{tabular}{|c|c|c|c|c|c|c|}
\hline Aguardente & Destilação & $\begin{array}{l}\text { Álcool } \\
\text { vinho } \\
(\% \mathrm{v}) \\
\end{array}$ & $\begin{array}{l}\text { low wines } \\
\text { (\%v álcool) }\end{array}$ & $\begin{array}{c}\text { Álcool } \\
\text { destilado } \\
(\% \mathrm{v})\end{array}$ & $\begin{array}{c}\text { Volume } \\
\text { destilado } \\
(\mathrm{ml})\end{array}$ & $\begin{array}{c}\text { Rendimento } \\
\text { Prático } \\
(\%) \\
\end{array}$ \\
\hline \multirow[b]{2}{*}{07} & $1^{a}$ & 7,06 & - & 47,65 & 1600 & 89,9 \\
\hline & $2^{a}$ & - & 6,25 & 59,62 & 500 & $39,75^{*}$ \\
\hline \multirow{5}{*}{08} & & 8,50 & - & 25,99 & 3500 & 89,2 \\
\hline & & 8,20 & - & 25,64 & 3500 & 91,2 \\
\hline & $1^{a}$ & 7,34 & - & 27,02 & 2950 & 90,5 \\
\hline & & 7,06 & - & 26,94 & 3000 & 95,4 \\
\hline & $2^{a}$ & - & 25,90 & 60,73 & 4750 & $92,8^{*}$ \\
\hline \multirow{5}{*}{09} & & 8,50 & - & 25,99 & 3500 & 89,2 \\
\hline & & 8,20 & - & 25,64 & 3500 & 91,2 \\
\hline & $1^{a}$ & 7,34 & - & 27,02 & 2950 & 90,5 \\
\hline & & 7,06 & - & 26,94 & 3000 & 95,4 \\
\hline & $2^{a}$ & - & 25,90 & 46,58 & 2500 & $37,5^{*}$ \\
\hline
\end{tabular}

* Estimativa. 


\section{APÊNDICE C}

Tabela 1C - Propriedades Físicas. Compostos Voláteis.

\begin{tabular}{cccc}
\hline Composto & Peso Molecular & $\begin{array}{c}\text { Ponto Ebulição } \\
\left({ }^{\circ} \mathrm{C}\right)\end{array}$ & $\begin{array}{c}\text { Solubilidade } \\
\left(\mathrm{g} / 100 \mathrm{~g} \mathrm{H}_{2} \mathrm{O}\right)\end{array}$ \\
\hline Ácido Acético & 60,05 & 118 & - \\
Aldeído Acético & 45,06 & 20 & - \\
Acetato de Etila & 88,11 & 77 & - \\
Acetona & 58,08 & 56 & - \\
Metanol & 32,04 & 64,5 & - \\
n-Propanol & 60,10 & 97,2 & 10,0 \\
I-Butanol & 74,12 & 108 & 7,9 \\
N-Butanol & 74,12 & 118 & 3,6 \\
I-Amílico & 88,15 & 128 & 2,3 \\
N-Amílico & 88,15 & 138 & \\
(1-pentanol) & & & \\
\hline \hline
\end{tabular}

